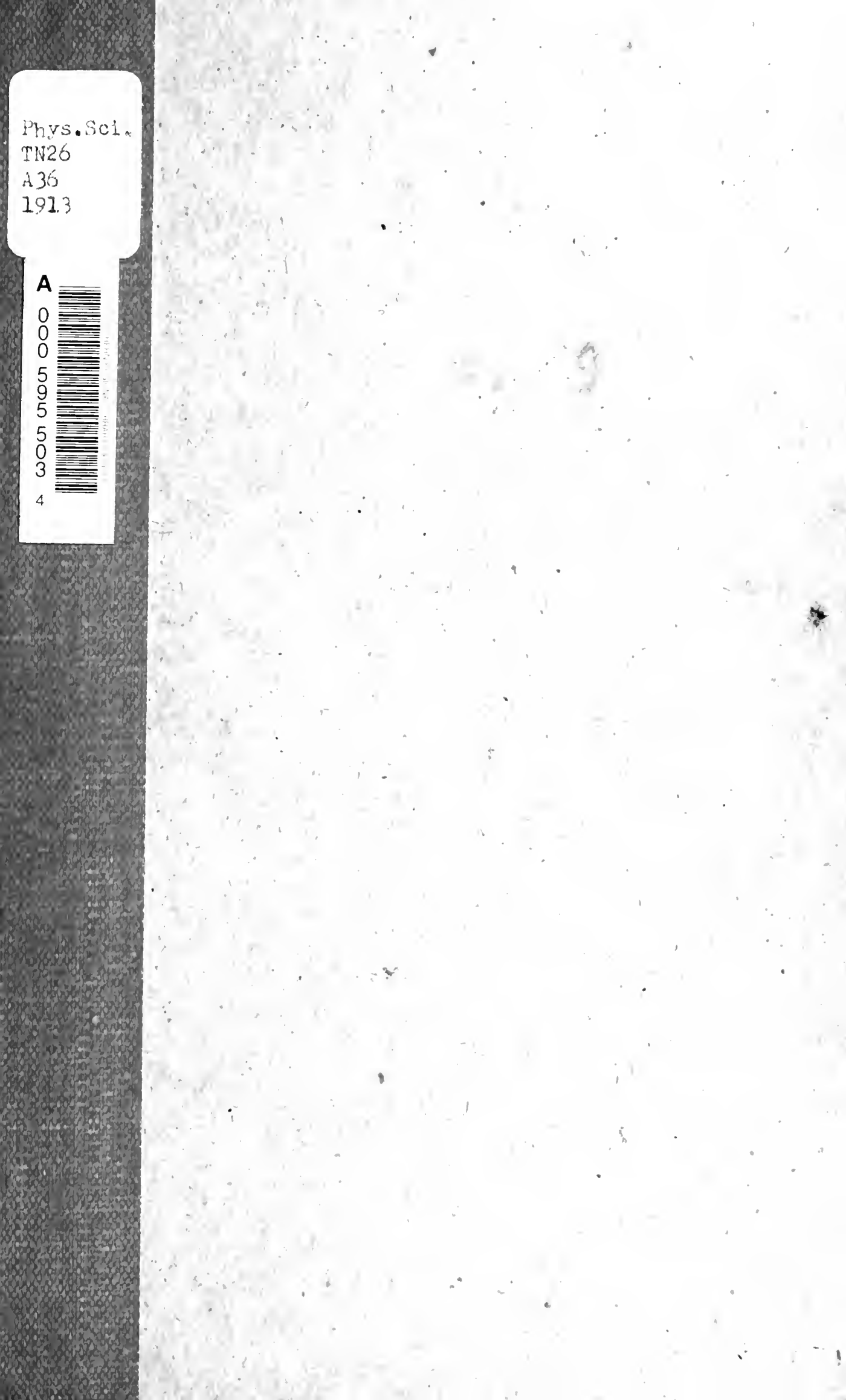


Physical Sciences Library University of California Riverside. 


\section{ECONOMIC MINERALS}

AND

MINING INDUSTRIES

OF

\section{CANADA}

\section{MINES BRANGE}

DEPARTMENT OF MINES OTTAWA, CANADA? 




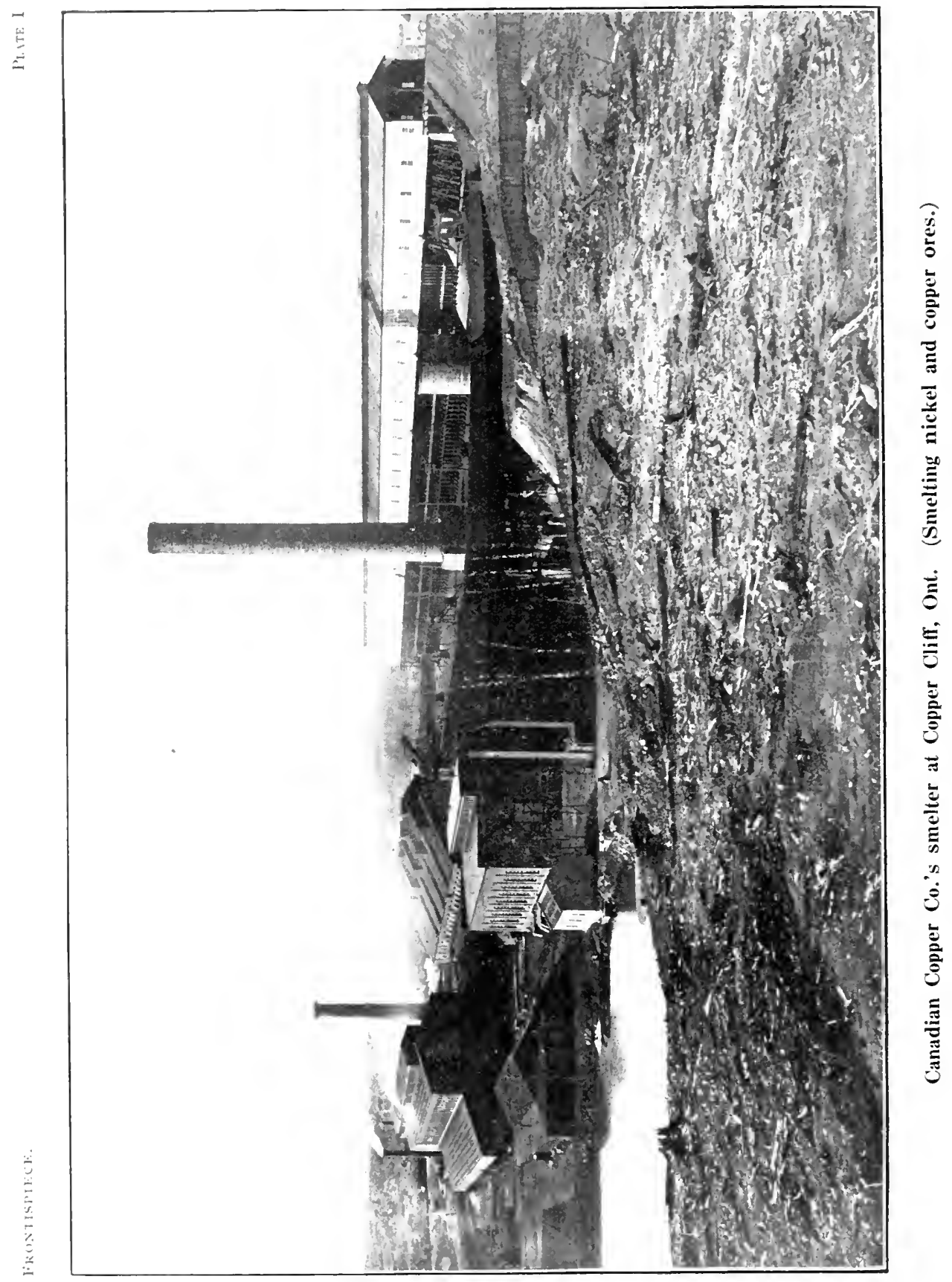




$$
\begin{gathered}
\text { CANADA } \\
\text { DEPARTMIENT OF MINTES }
\end{gathered}
$$

Hon. Louis Coderre, Minister; A. P. Low, Ll.D., Deputy Minister;

$$
\text { MINES BRANCH }
$$

Eugene lianel, Ph.D., Director.

\title{
Economic Minerals and Mining Industries
}

\author{
$\mathrm{OF}$ \\ CA I I D A \\ BI \\ TH E S T A F F \\ OF THF
}

MI!I NES B R A N C:H

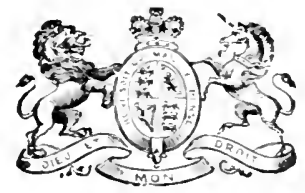

OT TA II A

GOVERNMENT PRINTING BLREAL 
4 


\section{CONTENTS.}

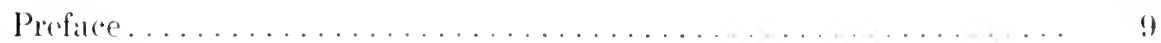

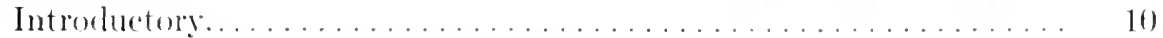

Minctal production of canala in $1912 \ldots \ldots \ldots \ldots \ldots \ldots \ldots \ldots . \ldots \ldots$

Economic minerals and assomeded industries................ 16

Motallic minerals-

Aluminimm . . . . . . . . . . . . . . . . . . . . .

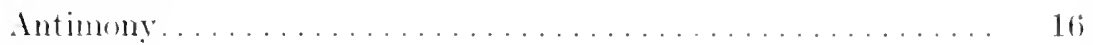

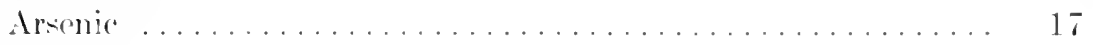

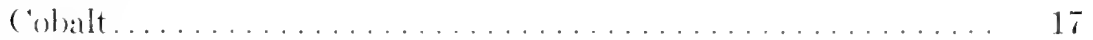

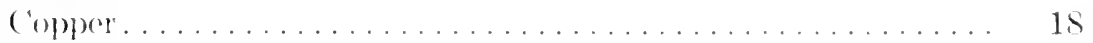

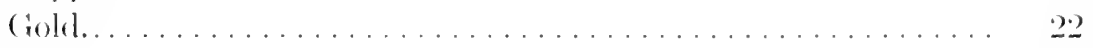

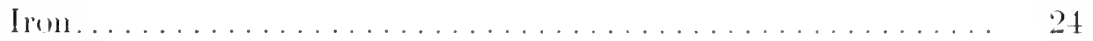

I

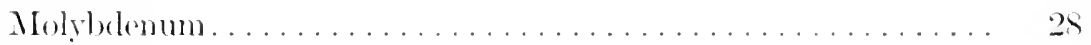

Nickel. . . . . . . . . . . . . . . . . . . . . . . . . . . . $2 !$

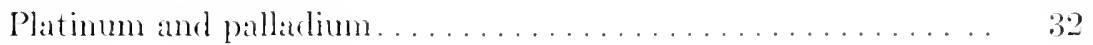

Silver. . . . . . . . . . . . . . . . . . . . . . . 32

Tin................................... 34

Tungsten.............................. 34

Zinc................................

Non-metallic minerals-
Astbestos..........

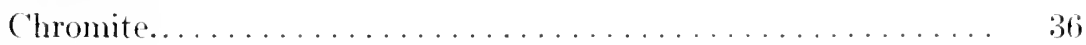

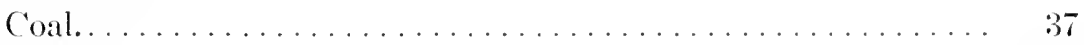

Corundum . . . . . . . . . . . . . . . . . . . . . . 44

Feldspar. . . . . . . . .

Fluorspar. . . . . . . . . . . . . .

Graphite............................ 40

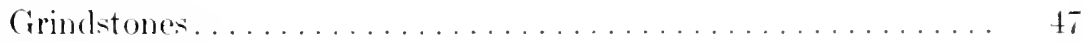

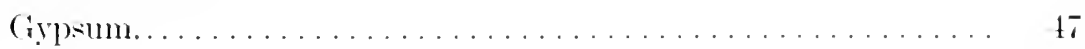

Magnesite. . . . . . . . . . . . . . . .

Manganese. ...............................

Mica. . . . . . . . . . . . . . . . . . . . . .

Mineral pigments..........................

Iron oches. . . . . . . . . . . . . . . . . . . . . 49

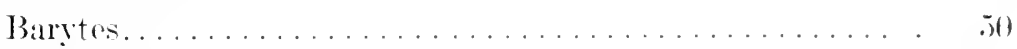

Mincral water. . . . . . . . . . . . . . . . . . . . . . . . . . . . .

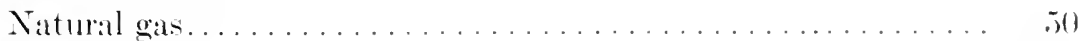

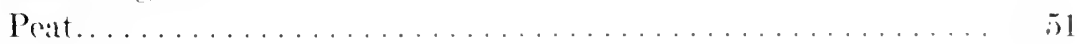

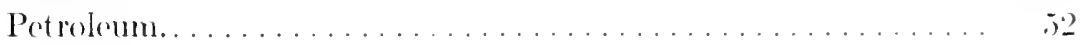




\section{CONTENTS Continued.}

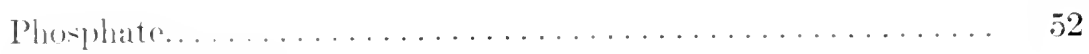

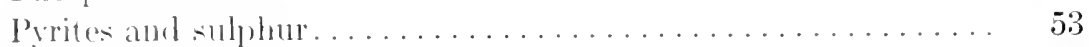

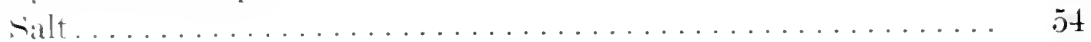

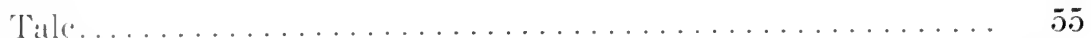

Tripolite. . . . . . .

Clay and quary products-

(iment .

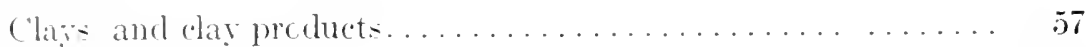

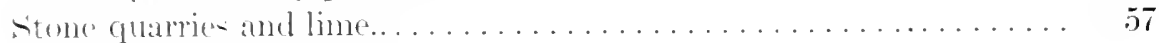

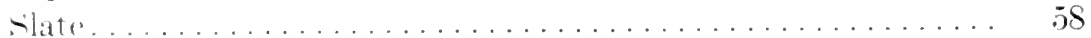

Statisties and mining laws-

Noval fiential. . . . . . . . . . . . . . . . . . . . . . . . . 60

Xor Brmswick. . . . . . . . . . . . . . . . . . . . . . 62

Prince Elward Istand......................... 63

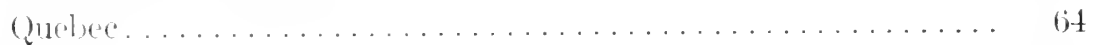

()ntario . . . . . . . . . . . . . . . . . . . . . .

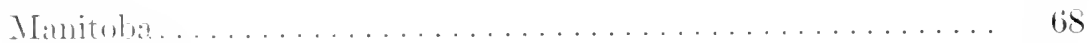

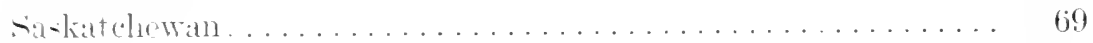

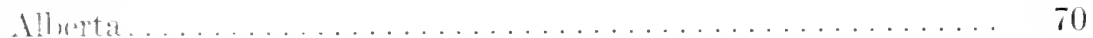

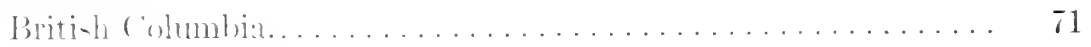

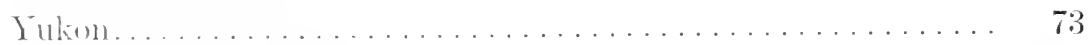

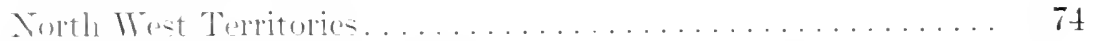

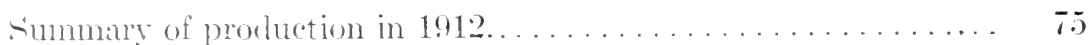

Annual statistice of problustion in Camarla since $1586 \ldots \ldots \ldots \ldots .76$

Bonnties mineral proluction . . . . . . . . . . . . . . . . 76

Ore and Fuel Testing Latheratories................... Ti 


\section{ILLLSTRATIONSS.}

PHoTOGRAPHs.

Plate I.-Camadian Copper C'o's smelter at copper ('liff, Ont...

(Simelting nickel and copper ores) . . . . . F Frontispiece

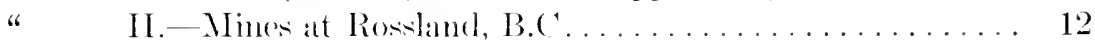

" III. - Mother Lode mine near Greenwool, B.( ........ 12

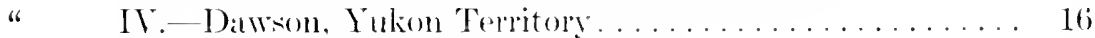

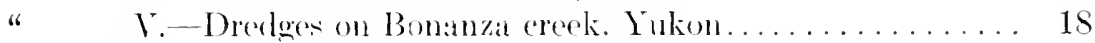

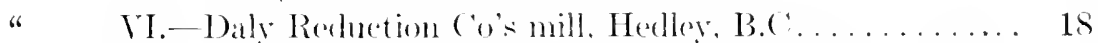

" TII.-Blast furnale plant at syelney Mines, N.S. (Noral

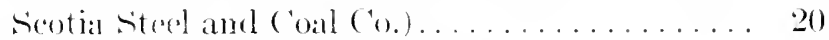

"VIII.-Helen iron minc. Michipicoten, Ont.......... 24

" IX.-Blast furmare and ore flocks, sault site. Marre, Ont.. 24

" X.-Conper anel leal smelter at Trail, B.( ......... 28

" XI.-Electrolytic leal pefinery at Trail, B.C .......... $2 S$

" XII.-Creighton nickel-oopper mine, Ont., Canalian (opper"

('0......................... 30

" XIII.-Power plant, IIigh Falls, Spanish river, Camalian Copper ( $0 \ldots \ldots \ldots \ldots \ldots \ldots \ldots \ldots \ldots \ldots \ldots \ldots$

" XIV.-Mines in Kerr Lake section, (obalt district. . . . . . 34

" XV.-Silver voin, Cascy Cobalt mine, Cobalt distriet..... 34

" XVI.-Asbestos quarry, Black Lake, Que............. 36

" XVII.-Colliery Dominion No. 2, Dominion Coal C'o., Cilace Bay, N..................... 40

" XVIII.-Coal Creek colliery, Crows Nest Pass coal Co., Fernic, B.(.................. 42

" XIX.-Gypsum quary, (heverie, N.s........... ts

MAP.

No. 232.-XIneral XIıp of Camala................. In pocket 

ECONOMIC MINERALS

AND

MINING INDUSTRIES

OF

CANADA

1913 



\section{P R E F A E .}

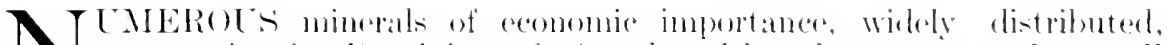
orem in the bominion of ('anala, althomgh, as yot, only small fractions of the probahle productive areas have heen carefully pres-

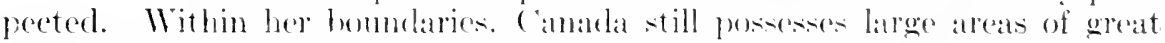

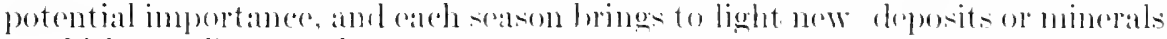
not hitherto discosereml.

This pamphlet has been compiled under the direction ol Mr. J. MeLoish,

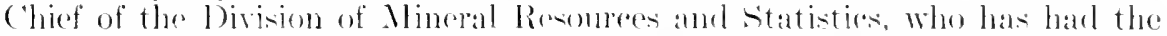

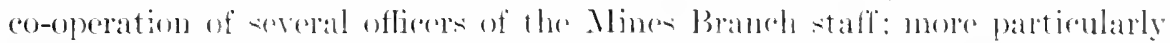

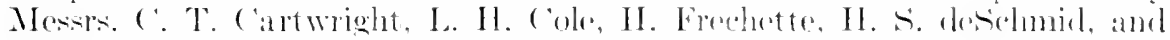
A. IV. (i. Mökon: and the objeretive hats beren to present in a populate form a brief sketeh of the more important reomomic mincrak, and of the minimg and metallomgioal inchetries of ('amata.

A short introductory statement, giving some data of general interest,

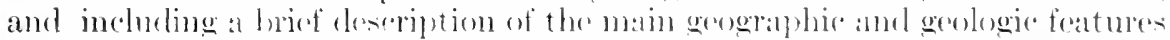

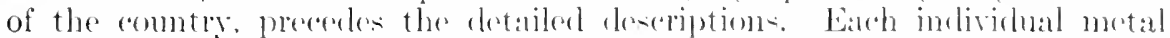
or mineral probluet is treated soparately, allul arrateged in alphabetical order.

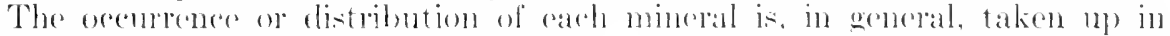
geographical oreler, from aset to west. At the ond of the pamphlet hrief

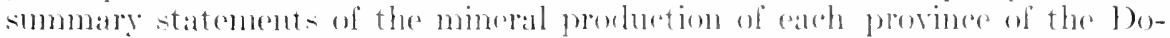

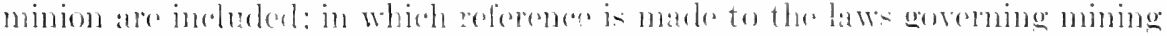

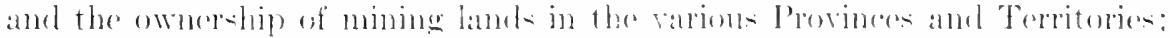
and the names and aldereses ane given of the sereral govermment depald-

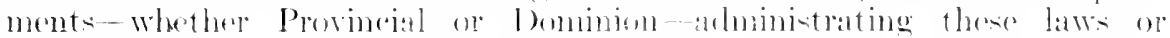
regulations.

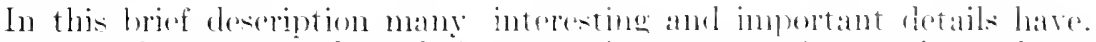

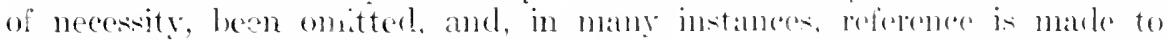

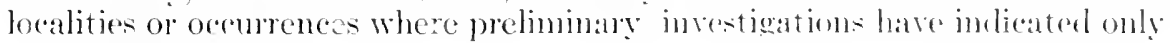
future possibilities.

The particulars and statisties have all beren eompilen from offiedal sourees.

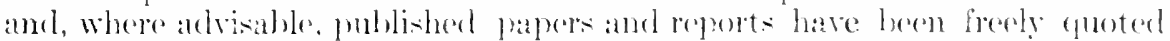
from: for which, gemelal ardinowlerlgment is here mate.

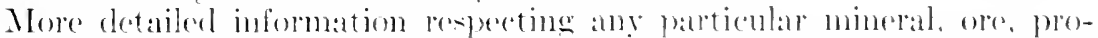

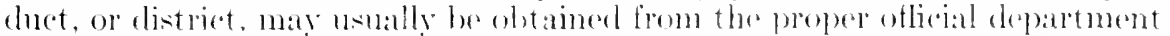

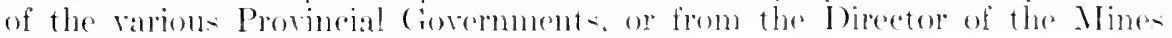
Branch of the Department of Mines. ottawia.

\section{(rignol) Eugene Haanel,}

Directors.

June 4, 1913. 


\title{
MINERAL RESOURCES AND MINING INDUSTRIES OF CANADA.
}

\author{
INTRODLCTORY.
}

The Dominion of ('anata oceupies the northern portion of the eontinent of North America exclusive of Alaskat all the Aretie islands between Greeniland

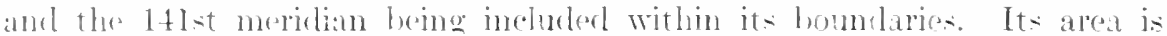

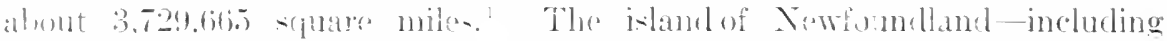

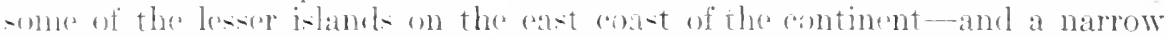
-trij) of land along the atjareent Latharbor coast, forms a separate colong,

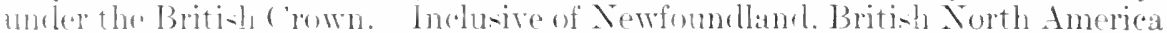

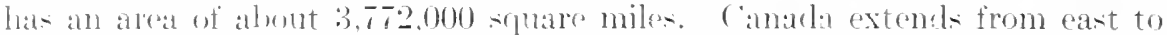
west alunt 35000 miles, and from north to south about 1400 miles. The most sonthern point is in Exox county, Province of (Intario, near latitude $42^{\circ} 16 i^{\prime} \mathrm{X}$.

This larer area necesiarily presents great diversity of topographic fratures, and strata of norly all geological horizom are representerl. On the lasic of certain structaral foatures, it is posible to recognize six great physiographic units. The greatest single structural unit eorers an area of orer 2.000.000 spuare miles. This mit extends, in a more or lese L shape, from Iabralor on the arst to coronation gulf on the west, bordering the great Hulsom Bay depresiom. It is underlain by a mass of ancient crystalline rowlis. vory diverse. and highly metamorphosed - the roots of the most ancient mountain range on the continent. These mountains were probably the first land areas of the North American continent. The originally orerlying portion: were gradually removed by rarjous erosive processes, until now, throughont this rast area, mountain forms are no bonger seen; but their basal structures still remain. So great has been erosion, that the region is now characterized almost ererrwhere by the existence of remarkably even skylines. Here and there. low domed residuals rise a few feet above the general level, making notalle breaks in the otherwise nearly even surface.

- In detail the topography of this area is characterized by innumerably small chomes and hasins, with a relief of only a few hundresl feet or less. Scattered orer it: surface are numberless small and large lakes, with numerous sleams, which exhibit many rapids and falls. Nowhere else in the world arr-mall lakes and comnecting streams so plentiful and so widely distributed. The greatre portion of the southern part of the region is eovered with dense forents of mruer. The highes portions of the area in Labrator, and the extheme northern portion of hoth the eastern and western limbs, are nearly Ifetitutrof tros; although some few orcur in protected basins. The remarkably aren skline and artain other foatures which characterize the region at: a whele, have anderel it to he designated the Laurentian Peneplain. It is,

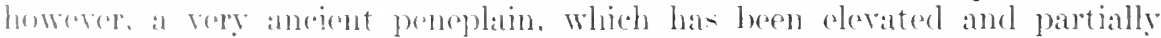

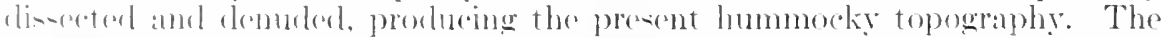
deration of the plane, as shown hy the skylines, raries from about soo feet 


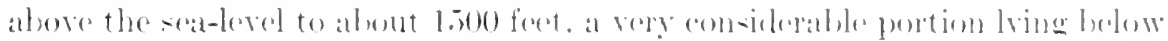
the $1000 \mathrm{ft}$. contome. The alles is sometimes known as the Laurentian P!ateau.

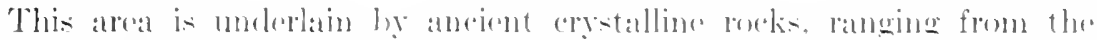
Laurentian to the Kewernawan formations. It is a region of ereat poten-

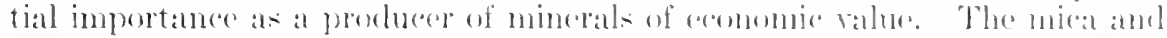
phosphate deposits of the ()t tawa valley: the silver mines of ( oh)alt: the erold

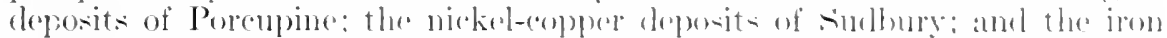
mines of the Michipicoten alistrict, all aceur within this region. It impor-

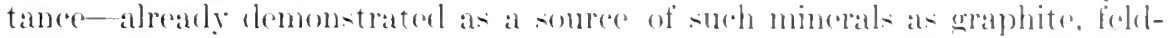
spar, mica. corundem, iron ores, hoth magnetites and hematites, silver, cobalt, copper, nickel, and golel-will, melouhtedly, he greatly extromed in the future.

The Hudson Bay basin oecupies a central depresion in the Laturentian peneplain. The hay itsolf is a great inland soa. some 600 miles from east to west, and nearly 1000 miles from north to south. Bordering the southern and southwestern portion of this hasin, is an alrea molerlain hy Palcozoic rocks. sloping gently hayward, which may he dexignated the Hudson Bay Coastal Plain. At present this region is litgely unexplored, but is known to contain deposits of rock salt and grypium.

Soutleast of the Laturentian plateau, including a portion of the province of Quebee (south of the sit. Lawronce river and east of sherlnowes ant the whole of the Maritime Provinces. we find the northem axtremity of the bealt of Appalachian mountain folks. which extenek along the Atlantic coast of the continent. This area was termed the Acadian region by Dawon. It is underlain chiefly by Paleozoic rocks. which have heen subjected to considerahle folding, and, afterwark, were degraded. () the extrene east, on the Tora seotia coast, a number of basins contain resiluals of the carboniforous system, in which rery important coal finds ocems. A larere but shallowere basin of earboniferois rocks also ocens in Now Brunswiek. The other

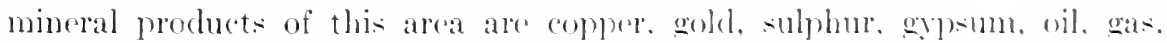
sandstones, limestones, days and buileling and omoumental stones of various kinds.

The next important phrsiographic unit is the ancient helted coastal plain which now forms the st. Iawrenee drainage basin the St. Lawrence basin). It extends from the eity of Queber to Lake Hurom, and includes the st. Lawrence lowland in the vieinity of Mentreal, and the lowland areas in the provinee of (Ontario, alliacent to the great lakes. This region is under-

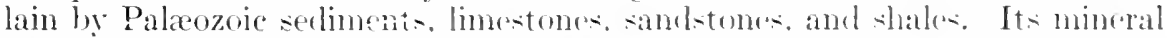
products are salt, gypoum. natural gas. potpoleum, building stomes. brick clays, and the raw materials of variom erments. limes, and mortars. This

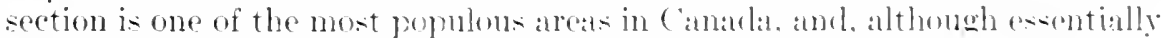
an agrieultural areas a very comsiderahle pereentage of the people are connected with the industries which arise through the ocourrence of these natural prosluets.

Westward of the Laumentian platean. from the city of Winnipex and Lake Vimniper, we haw the Great Plains area, or the Interior Continental Plateau, extending to the foothills of the liocliy mombtains, a distance of

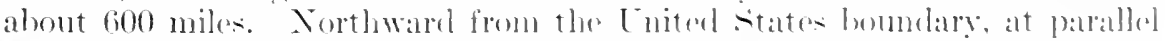
$49^{\circ}$ X.. to the Aretic orean, is a distance of albent leson miles. This areat includes two great liver hasins: the saskatchewan hasin on the somth, and the Mackenzie basin on the nopth. the divide hetween them lyine not far from $56^{\circ} \times$. latitude. The entire area is underlaid hy sellimentary strata, ranging in age from carly Palaezoie to later. Mesozole. The soutlerm part of the area. inchuling the greater portion of the siskiatcheran basin. forme the great 


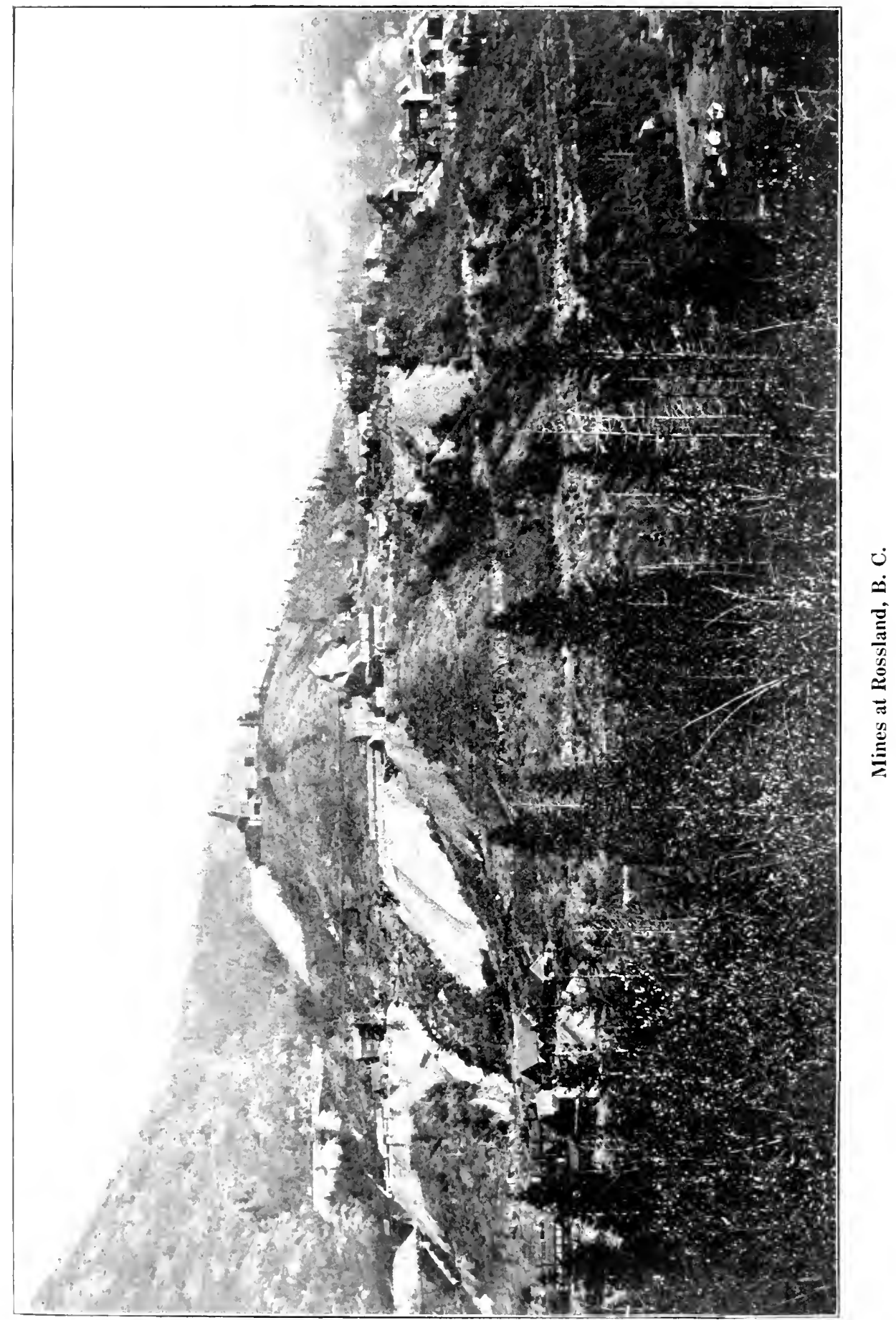




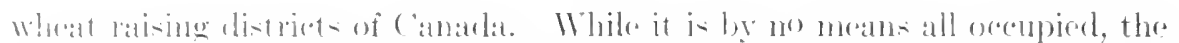

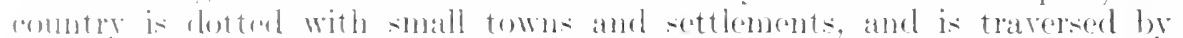

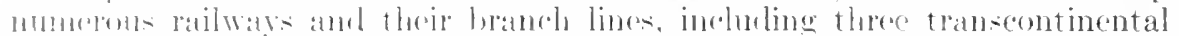
-r-tems. The nerthern part of the areat. incheding nearly the whole of the

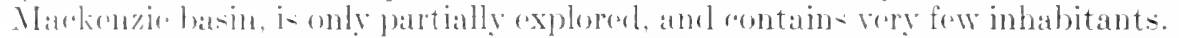

The southern parts produere natural gas. building stones and the raw matcriats for cements and mortals. The northern part is known to contain dreposits of rock salt, growm, coal, and tar sands, and it will also produce natural gats, ancl, probihly, petrolem. The stream beds along the westem alge of the area contain immense gravel deposits wathed down from the momatams, some of which alre known to be auriferous. The most important mineral prouluet of the arra. howerer, is lignite eal, which oecurs rery widely distributerl oxer the western portion of the area, and especially in the southern parts: many of the seams are quite thick, and the deposits form an exceedingly. important souree of fuel for the western provinces of Canata.

The mountain belt of British Columbia and the Yukon constitute the mext great physiographic unit. This is the northem portion of the great Cordilleran belt, which extends atong the whole western sicle of the Forth American continent, from Central Ancriea to Alaska. The Canadian portion of the belt is about 1300 miles in length. On the eastern flank of this ('ordilleran belt, we have the Rocky Mountain ranges, composed chiefly of Paizerzoic and Mesozoic rocks. This mountain belt is particularly important, breanse of the immense rescress of bituminous eoal of Crotaceous age, found in many secotions of the ranges.

Westwarl of the Rocky monntains. lie a series of mountain ranges, collectively designated as the Gold ranges. They are eomposed of Archean rocks, with which are astociated granites and a great thickness of older Palcozoic berls, all much disturherl and metamorphosect. Westrard of these ranges lies a section of country with somewhat iliversified topography, which is wally decribed ats the Interior plateau of British Columbia. Its wilth from east to west is about 100 miles; its extent from north to south probably ahout .000 miks. It differs from the mountain ranges to the east chiefly in the lack of any lofty momntain peak-; its main elevation is about 3.500 feet

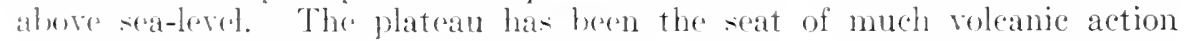
rluring Misenene times.

Beyom the platean to the north the whole wiolth of the Cordillera appears

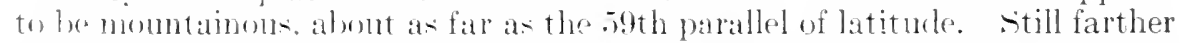
north the ranges deeline or diverge, and in the basin of the upper Yukon roll-

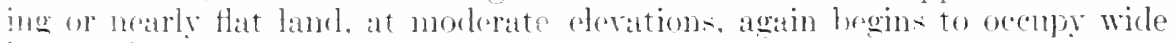
intervening tracto.

The western horeler of the cordillera, aleme the Pacific coast, is formed he the Coast range. This range runc northward from near the estuary of

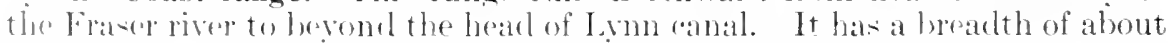
100 miles. It ansists largely of granite hatheliths. on the margins of which

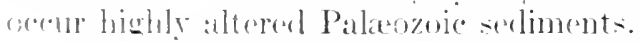

Buromit the coat range. near the erge of the antinental platean, a

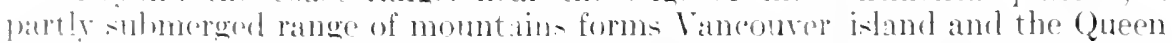

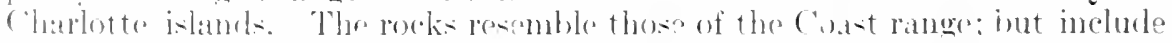

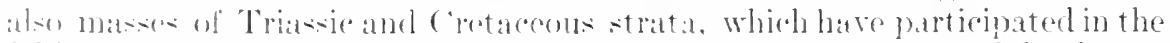

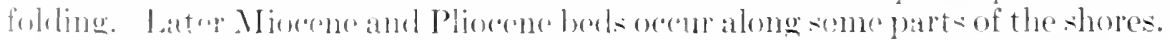

The comlilleran helt of Ameries is neter for it important deposits of

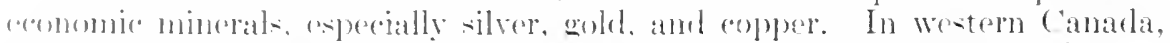

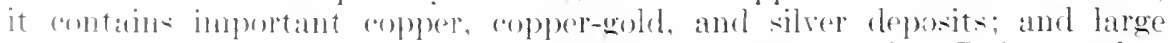

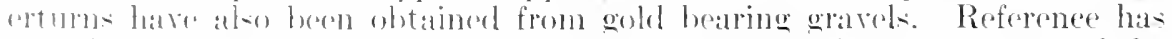

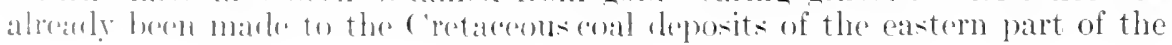


belt. Similar deposits of cretaceous age oceur on Vameonver island, and have been for many years the most important sonree of fuel on the Pateific coast. The cordilleran region of canala, when fully explored, is, moloubtedy, destined to beeome one of the most important mining seretions of the world.

The following tabulated statement slows the mineral probluetion in

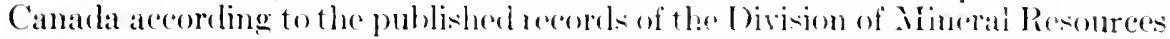
and Statisties of the Mines Branch. The quantities of metals shown include not only the product of refmeries. ate., which is compatratively small, but also the inetals contained in smelter products produced and the metals estimated ats recovered from ores produced and shipped ontsinle of Canada for treatment.

The metals are valued for statistical purposes at the market value of the refined product.

Non-metallie products are valued as shipped from the mines. The ton of 2,000 lbs. is used throughout.

A record of the production in each of the provinces will be found at the end of the report. 
Mineral Production of Canada in 1912.

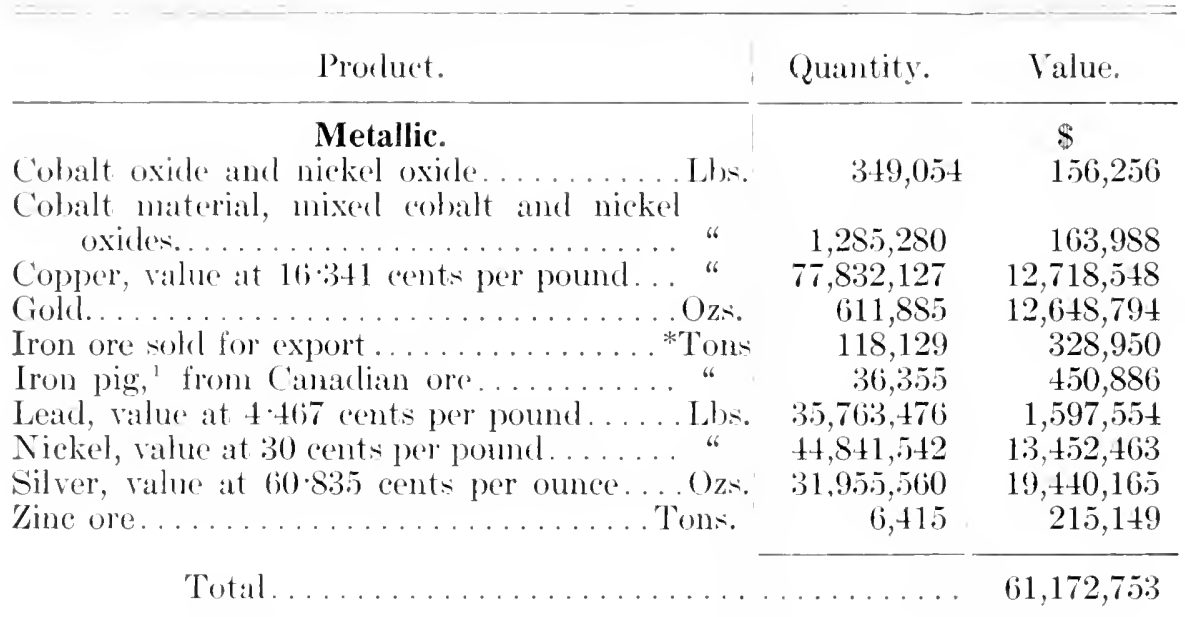

Non-Metallic.

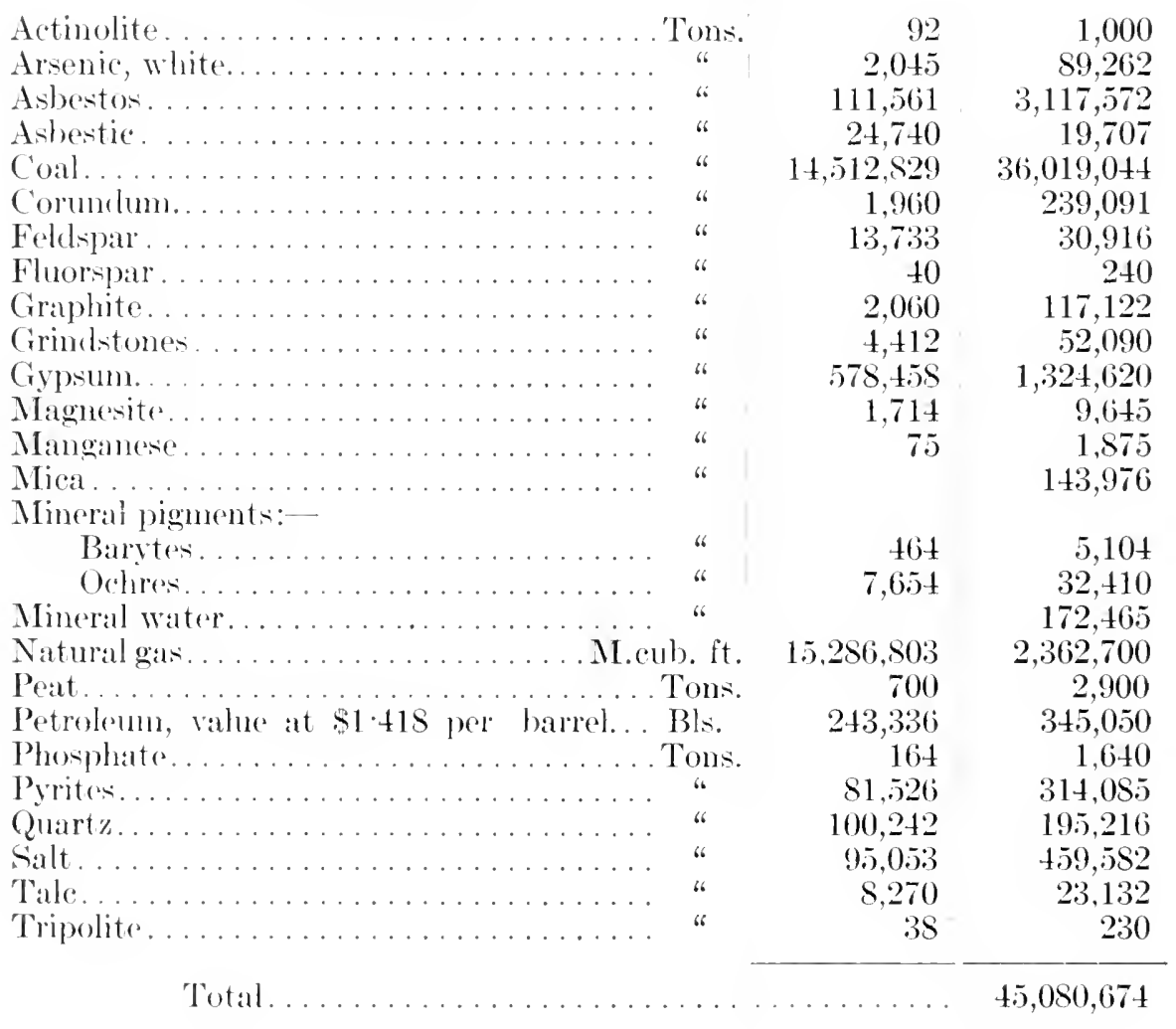

* All tons of 2000 libs.

1 The total production of pig iron in 1912 was $1,014,58$ - tons, valued at $\$ 14,550,999$, as compared with 917,535 tons, vilued at $\$ 12,307,125$, in 1911 . 
Mineral Production of Canada in $\mathbf{1 9 1 2}$ Continued.

Product. $\quad$ Qumitity. Vilue.

\section{Structural Materials and Clay Products.}

Cement, Portland.

Brick, conmmon. .

6

6

presied...................

pating. . . . . . . . . . . . .

"6

moulded and ornamental
Clay products: $(\$ 10,575,709)$

Bls.

Fircclay and fireclay products.

Fireproofing and architectural terra-cot ta

Pottery

Sewerpipe.

Tile, drain

Kaolin

Lime.

Sand-lime brick.

Sand and gravel (partial record)

Slate.

Stone

$(7,726,171)$

Bus.

No.

sip.
$7,132,732$

$769,191, .532$

$12.5,180,422$

$4.579,500$

$371,3.56$

8.47 .5 .8399

$96,448,40^{\circ}$

Granite

Limestone

Marble.

Sandstone

Total

Grand total
20

$9,106,5,56$

7.010 .37 .5

$1,(60) 9,5.54$

8.5 .989

$8,59.5$

$12.5,58.5$

448.853

4.3,9.5.)

$8 s+6+1$

357.862

160

$1,814,849$

$1,0: 20,356$

$1,512,099$

$1,89+\quad 8,939$

1,373,119

$2,762,936$

$260,76 \mathrm{t}$

329,352

$28,794.869$

$13.5,048,296$ 


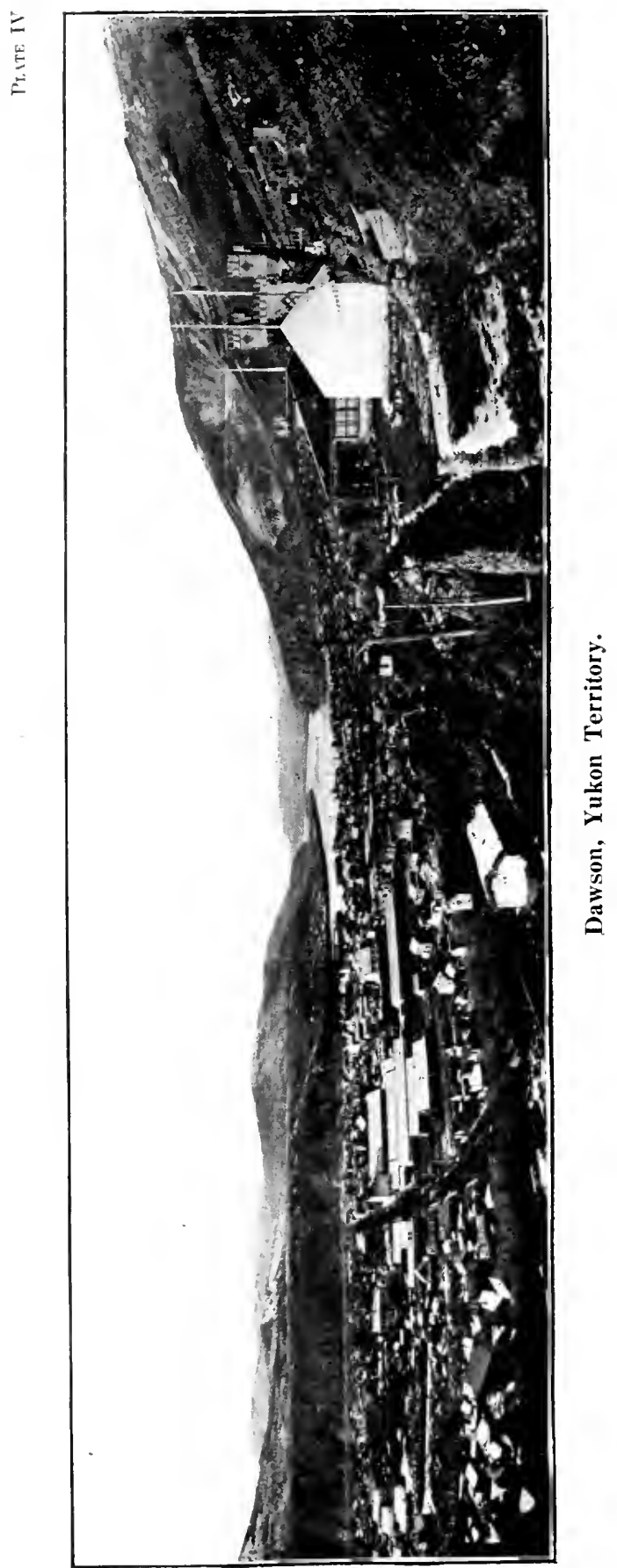




\section{ECONOMIC MINERALS AND ASSOCIATED INDUSTRIES.}

\section{METALLIC MINERALS.}

\section{Aluminium.}

Bauxite the commereial ore of aluminium has not yet been found in Canada but the metal aluminium is produced from ores imported from France, Germany, and the Enited States, in extensive reduction works situated at Shawenegan Falls, Quebec. The plant is operated by the Northern Aluminium Company, a subsicliary of the Aluminimm C'ompany of America. A portion of the banxite used at thes works is mined from the Company's mines in the States of Arkansas and Georgia, and refined at East st. Louis, U.S.A.

The Shawenegan plant eovers an area of about 10 acres and includes reduction buildings and a wire mill. The Company employs the Hall, or Heroult electric reduction process for the manufacture of aluminium. The furnaces, or cells as they are locally tormed, are rectangular in shape, the bottom of the cells forming one electrode, while a number of carbons suspended over the cells form the other electrode. These cells work continuously, the reduced metallic aluminium collecting at the bottom, whence it is tapped off from time to time, and moulded into bars. There are 340 eells in operation, each producing, on an average, 150 pounds of aluminium, of 99. to fine per day.

The Company owns and operates a water power plant developing about 40,000 horse-power.

There are numerous oceurrences of feldspar in C'anarla, some of which are very pure, and it is possible that with improved procesios of manufacture, these may become important sources of aluminium in the future.

The exports of aluminium in ingots, bars, ete., from (anada during 1912 were 9,143 tons, valued at $\$ 2,002,363$, hesiles manufactures of aluminium valued at $\$ 10,898$.

\section{Antimony.}

Ores of antimony consisting mainly of stibnite or sulphide of antimony have been found and worked in a number of localities in rastern ('anatil, chief among which are the mines at West Gore in Hants county. Noval Scotiat, and in the Parish of Prince William, Sork county, Now Brunswick. In both cases mining operations have beon intermitent in character, and the total shipments of ore and concentrates during 2.) years does not seem to have exceseled 7,000 tons. The ore at West. Gore is auriferous, alt hough the presence of gold was not recognized in the earlier shipments which consisted of high grade ore carrying 50 per cent and upwands of antimony. A mill for treating low grade ore was built in 1907 and 1908 . No ore was mined or milled in 1912. Native antimony and stibnite ocenr at Prinee William. New Brunswick, and the deposits have been worked at various times since 1863. A small smelting plant was erected many years ago with a reputed production of a ton of metal per week. The Canadian Antimony ('ompany 
recoted a new plant in 1909 comsisting of stack furnaces and a reverberatory furnate for reducing the antimony oxide, the latter furmace having a capacity of from two to three toms of metal per 24 hours. This plant is also idle at the present time.

In andition to the above there is an oceasional recovery of the metal in the leat smelting and refining plant at Trail, B.C., antimony being a minor constituent of some of the silver-learl ores of southern British Columbia.

The ocenrence of antimony minerals has also been noted at South Ham, in Wolfe county, province of Quebere.

In British Columbia, stibnite has been reported at Watkinsons about 23) miles above Lytton, on the Fraser river; on Cadwalladar creek, Lillooet clistriet; on the Alps and Alturus claims, north fork of Carpenter creek, slocan district, and in the Atlin district on the west shore of Taku Arm, ahout 10 miles north of Golden Giate. Occurrences have also been noted in the Yukon district on a small stream flowing into the Stewart river about 5 miles above Gordon Landing, while more recently important antimonysilver veins have been found on Carbon and Chieftain hills in the Wheaton River elistriet, northwest of Lake Bennett in the southern Yukon.

\section{Arsenic.}

Arsenopyrite or mispickel ores are found abundantly in eastern Ontario, particularly in the county of Hastings. These deposits are usually auriferous and the Deloro mine in Marmora township was worked for many years for the recovery of both gold and white arsenic.

In northern Ontario, mispickel has also been found in quantity on the shores of Net lake near Lake Timagami; in Davis township, Nipissing district; near Schreiber on the Canadian Pacific railway, and also in the Rainy River district.

For a number of years a small quantity of mispickel concentrate was produced at the gold mine operated at Goldboro, Nora Scotia. The arsenical concentrate was produced from the residue of the mill concentrates after the gold had been extracted by bromo-cyanicle.

The present production of white arsenic in Canada is being derived altogether from the silver-cobalt-nickel-arsenic ores of the Cobalt district in Ontario, the arsenic being reeovered as a by-product in the several smelting works situated at Thorold, Deloro, Orillia, and Copper Cliff, the latter plant having been recently closed down. The annual production of white arsenic during the past five years has been from 1000 to 2000 tons, the greater part of which is exported.

\section{Cobalt.}

Previous to the discovery of the now famous ore deposits of the Cobalt district of northern Ontario, the metal cobalt had already been noted as a constituent of the sulbury nickel-copper deposits, in fact a small recovery therefrom was reported 1892 to 1894.

The silver-cobalt-nickel ores of the Cobalt district are discussed under the article on silver, since these ores, with one or two exceptions, are mined primarily for their silver contents, the cobalt being a by-product for which the mine owners now receive no return whatever. This fact is rather curious, when it is remembered that these ores have displaced nearly all others in supplying the world's demand for cobalt. Although most of the ore producing veins of this camp are chiefly silver bearing, a number have been found in which the silver values are negligible. 


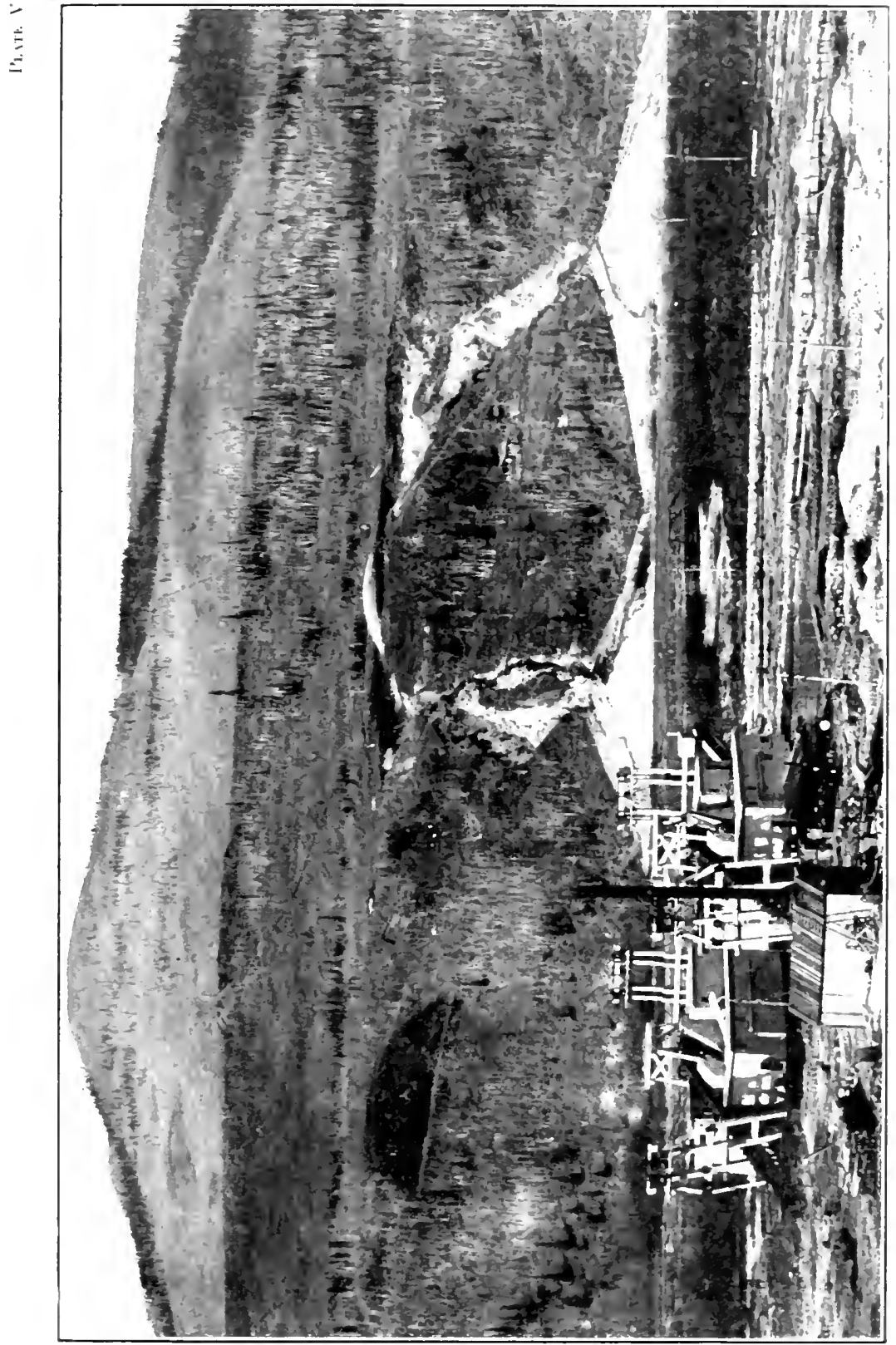

ב⿱艹 


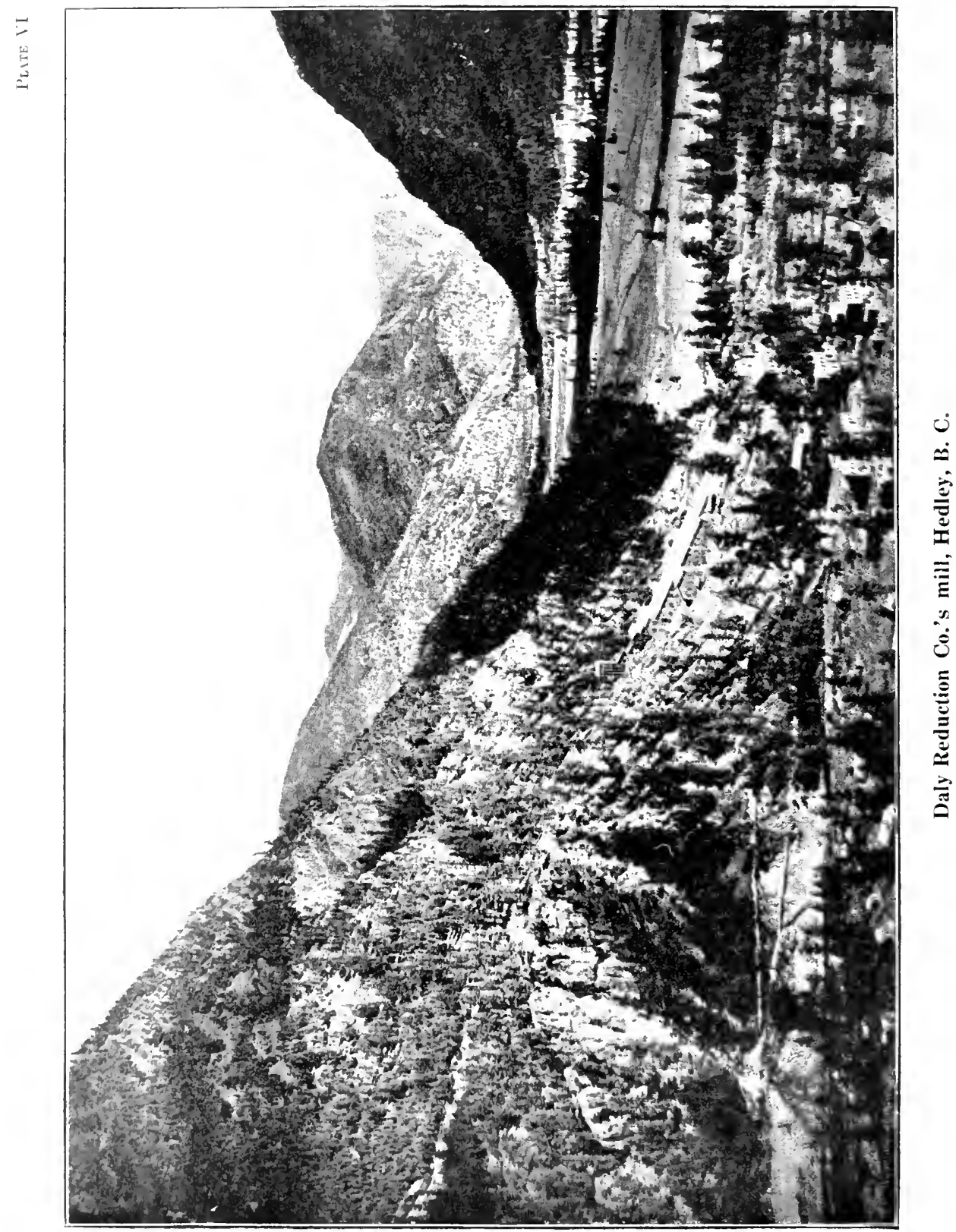


cobalt is being recovered, in the form of eobalt oxidr amel cobaltic material contaning nickel or nickel oxide and a little silvet, in Canalian smelters situated at Copper ('liff, Delero, Thorolel, (Orillia, and Xorth Baty resperetively. It is quite posibule also that recovery is being made in other smelters, outside of camada, to which a considerable tommage of these ores has been shipped. The produetion has been sufficient to cause a falling off in the price of cobalt oxide from 82.50 a pound in 1907 to less than a clollat a poumbl in 191.1 and 1912. It is estimated that in 1911 about 852 tons of metallic cobalt were contaned in the ores shipped from the (cobalt amp. About 21.5 toms of metals were reerovered in Canadian smelters contained in cobalt oxide, and 119 tons contained in "crule cobalt material."

\section{Copper.}

Native eopper oceurs in ('anada in a number of different localities; it has been found in the Maritime Provinces in the trap sheets which oceur on both sides of the Bay of Fundy: it is known to occur in Ontario, in eertain copper-bearing amygdaloids of the Keweenawan sories which oceur along the east coast of Lake Superior; it has been found in central British Columbia; and recent explorations have eonfirmed information obtained nearly a century and a half ago, that very important copper-bearing amygdaloids oceur along the aretic coasts of Canada, near Coronation gulf and in Victoria land. None of these deposits are being exploited commoreially. The small amount of exploration work performed in the more easily acecsible areas has not disclosed eoncentrations of native copper at these points in sufficient quantity to make it practical to operate them eommeredally by present methods, the content heing usually one por cent or less. The areas of copper-bearing rocks around coronation gulf hare not been investigated commercially ats yet. The preliminary reports avalable serm to indicate the ocenrence in this vieinity of copper ranges which cover an area greater than the wellknown copjier-bearing rocks of the state of Michigan.

Mincrals containing copper as an esiential comstituent oceur in many places throughout Camada. Those commercially important are the sulphides; carbonates and oxides alio oceur, usually in association with sulphide deposits, but they are relatively of minor importance. The two sulphicles, chalcopyritr and bornite, are the most important; locally whalcocite is also found occasionally. In Nova Sootia copper suphide minerals have been found at a number of points, but no important producing mines hare been dereloperl. The better known localities are: Cheticamp, Lochaber, and coxheath. In New Brmmswek, also, no ore bodies of known commereial importance have been diseorered, although small depesits have been foumd in a number of loealities in the southorn part of the province.

In Quebee, particularly in the distriet known as the Eastern Townships. numerous oecurrenes of the sulphide minerals have been discovered during the last serenty-five gears. Some of these discoveries wore important enough to warrant explorations and eommereial development, and many small mines have been in operation for varying periods of time. The types of ores which oceur in this province may be classified on the basis of their amposition an follows:-

Pyrite and chalcopyrite, nearly pure sulphides, the copper content varying from a mere trace to more than 12 per cont, as at Eustis, ('apclton. and elsewhere.

Pyite and chaleopyrite dissominated through a highly siliceous gangue. as at the suffield mine. 
Chalcoprite and hornite discminated through a calcarco-magnesian limestone, as at dotonvale and vicinity.

Bornite in a siliecons gangue, usually quartz, ats at Harrey hill.

Pyrhotite, contaning a small amount of chalcopyrite, as at the Memphremiagog minc.

Chalcoprite and prite with quarty, and associated with a basic jgneous rock, as at the old mines near st. Flarien.

Chalcocite, in small amount, associated with quartz, and, more rarely, with sorpentine, occurring in several localities, but relatively mimportant.

The most important producing district oceurs in the vicinity of Sherbronke, (Qundoe. At the present time there are two active mines in this district, one of which has been in continuous operation for about 30 years. There are also a number of properties that are worthy of further investigation. The ores from the active mines are almost pure prrites, containing some chalcopyrite, and oceasionally a little chalcoeite. The sulphur content of the ore, which runs over $40^{\circ}$, is utilized for the manufacture of sulphuric aciel, and the copper is then recovered from the cinder residues obtained at the acid works, by hlast furnace smelting, with other ores. The Queber sulphide ores of copper nearly all contain small amounts of gold and silver.

In Ontario, in addition to the oecurrences of native copper, to which reference has already been made, there are four different districts in which copper-bearing minerals occur. These, in order from east to west, are:-

North Hastings district, where some ehalcopyrite occurs in association with pyrites deposits.

Parry Sound district, where some rich pockets of bornite and chalcopyrites were found.

Suclbury district, where copper sulphides, chiefly chaleopyrite, occur in association with niekel sulphides in the well known deposits of nickeliferous prrmotite of that region.

North shore of Lake Huron, comprising the area westward from the Sudbury district to Lake Superior, and extending northward for at least 40 miles. In numerous localities throughout this area quartz veins, sometimes of consilerable width and lineal extent, are found. Many of these veins contain small flakes and masses of chalcopyrite, occasionally of considerable size. The number of recorded elaims is large; prospecting has been earried on in many localities and in some few instances extensive development work has sucerederl prospecting. Some of the earliest discoveries of copper ores in ( )ntario were in this district-at the old Wallace mine, now long since abanfonod, and at the woll known Bruce mines. Ore shipments have been made intermittently from a number of loealities in this distriet, but none of the properties have been operated continuously for any length of time. These ores are all highly siliceous. It has long been known that oceurrences of (o)per minerals are widespread in this distriet, and many prospects have heren discovered which eontain low grade ores. They have rarely been sufficiently explored to demonstrate their extent. The difficulty of recovering the coplere content economically has not been sumounted. Without some aldecuate method of concentration, it has not been possible to exploit the prosperets for any length of time in any locality.

In northern Ontario at the Alexo mine, near Matheson, chalcopyrite associatrel with a nickeliferous pyrrhotite occurs in serpentine. Mining (1) erations are in progress and a small tomnage of copper-nickel ore has already heren produeserl.

Copper sulphides have also been found in the district west of Port Arthur, where a little prospecting has been done, and in a number of localities 


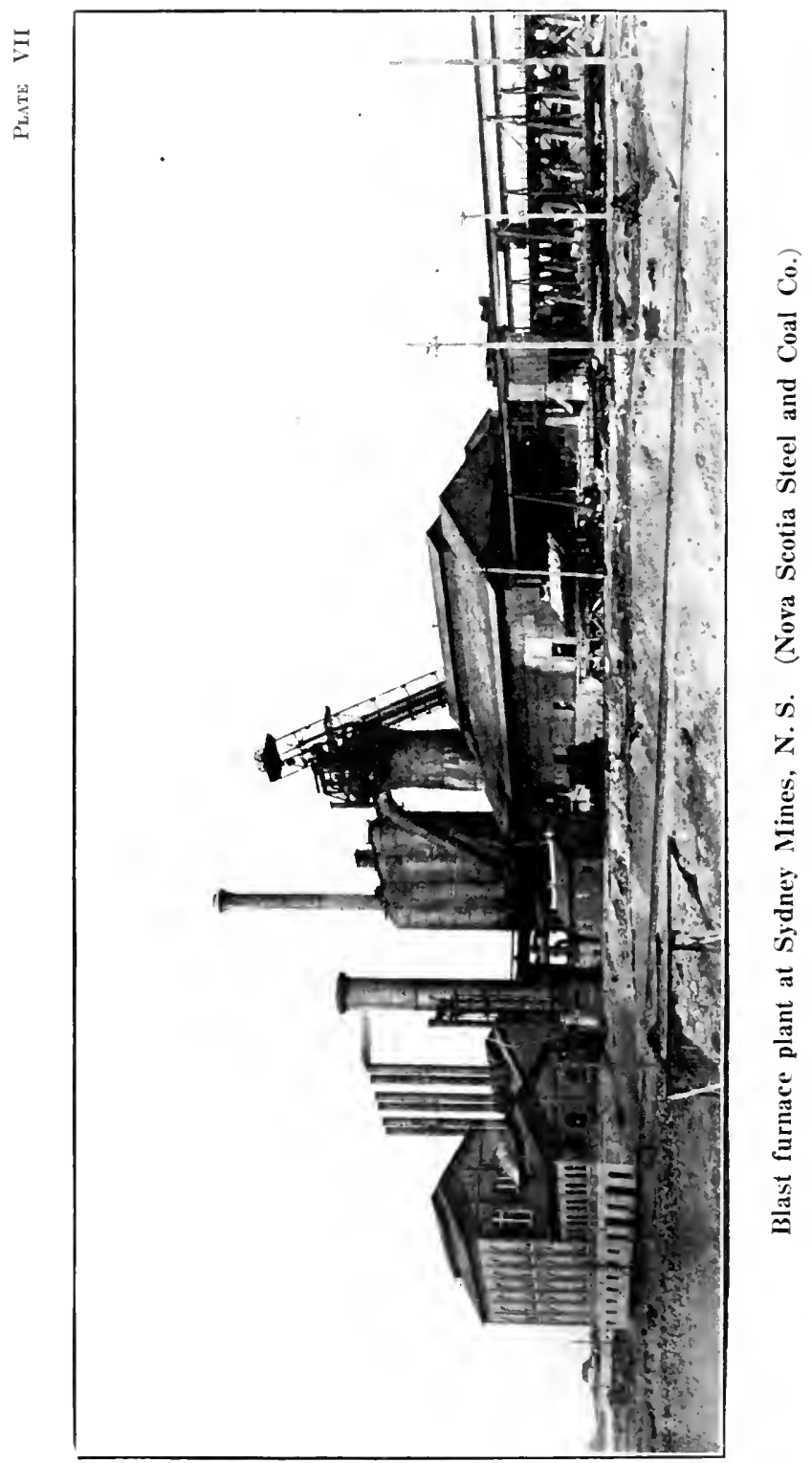


in the Timiskaming and Timagami districts. A small amount of eopper is recovered annually from some of the silver ores of ('obalt and ricinity.

(Ontario's procluetion of metallic copper in 1912 was $22,232,000$ pounds, valuel at $83,670,518$, on the hasis of the New York average market price for the vear. Nearly the whole of this was obtained from the pyrrhotites of the siulloury district. In this locality two large smelt ing plants are in active operation, treating ores obtained from their own mines by blast furnace smolting. A third company has been exploring other properties during the last few rears, and another large smolting plant will probably be ereeted in the near future. The ores are all nickeliferous copper-bearing pyrthotites and they also (ontain small amomnts of the precions motals. A more complete description of the ore borlies of the sindbury district is inclueled in the paragraphs dealing with the notal nickel.

British ('olumbia is at present the principal copper-producing provinee of the Dominion of Canala, copper-bearing minerals being found in numerous localities in various parts of the province. The important minerals are usually chaleoprete or bornite, or both. These may occur alone, but usually they are fomd in association with other minerals, the commonest of which are prrothotite, magnetite, pyrite, mispickel, ard, occasionally, blende and galena. The known occurtences are too numerous to be considered individually in a review of this character. The principal districts in which important discoverics have been made are in southein British Columbia, in the West Fontenay and Kambops distriets, and in the coast district at a number of points along the mainland and on some of the coastal islands. The most important active producing mines are at Rossland, at Phoenix and at MotherIodr in the interior, and at Britannia or Howe sound, Texada island, and Granby hay on the coast. Prospecting exploratory work and development is also being carried on at a number of points, both in the interior of southern British Coumbia and at several coastal points.

The ore deposits of Rossland oceur in fiswure reins and in locles or shear zones, the ore forming a network of reinlets in the fractures, and also replaeing more or lesis eompletely the intervening fragments of country rock, sometimes also partially replacing the wall rock. The ores may be classified, aceording to Brock, on the basis of their mineral contents, as follows:-

a. Pyrrhotite and chalcopyrite, with some pyrites and occasionally a little arsenopyrite, massive or mixed with gangue and rock matter. Free wold orenrs, though but rarely visible. Rarely, molybdenite and magnetite are foumd, and, on a few oceasions, blende and galena have been seen. This ore is the typieal ore of the district, and, at times, the pyrrhotite contains $0(6)^{2}$, nickel and 0$)^{5} 59$ cobalt.

b. Pyrrhotite, coarse textured and massive, containing very little eopper and little gold.

(. Veins of pyrite and mareasite with arsenopyrite and some blend and galena. Such veins oceasionally eontain silver as an important eonstitu('nt).

1. Impregnations of arsenopyrite, prrrotite, prite, molyblenite, a little chalcopvrite, bismuthinite, and native gold. These occur particularly in and arominl small pegmatitic or aplitic alkali syenite dykes.

e. Ciokl-hearing guartz voins.

The entrgate associated with the Rossland ores is usually more or less altererl comitry rock, with which is associated some quartz, and, in places, raleite. 'The prineipal valuable constituent recovered from the ores is gold, s) that strictly the ores should be classed as gold ores containing a little copper. The ores, however, are treated by blast furmace smolting and the gold is afterwarels recovered from the copper matte. The gold content of the ore varies 
from 0.4 to abont $1.50 m$ ones per ton: the silver varies from $0 \cdot 3$ to 2.5 onderes

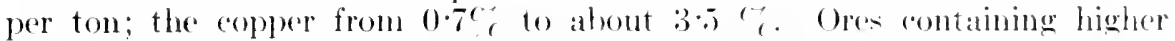
values in gold, or more copper, have beren fomel oreasionally.

The ore cleposits of the Bomblary district are, at present, the mont im-

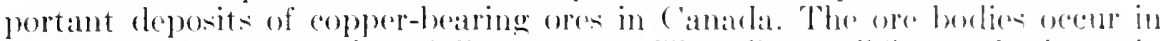
mineralized zomes in altereel limestones. They lie at dilforent horizons in

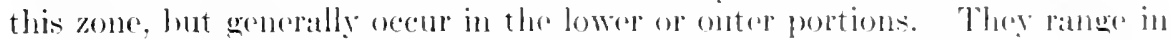
size from small lenses, foss than 20 fret in thirkness and 100 freet in longth, to huge ore bodies, such as that at the Knoh, Ilill-hronside mine at l'horenix,

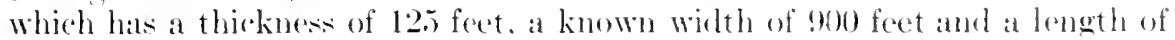
about 2.500 feet. The ore thromehont is rematkahly miform and is almost

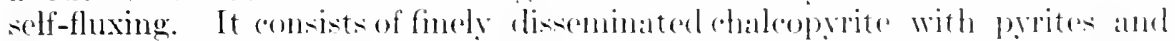

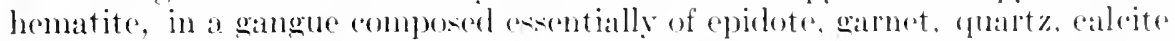
and chlorite. Magnetite ocens in distinct masese or lense-like bodies, both in and along the horders of the main ore bodies. The ehaleopyrite carries all

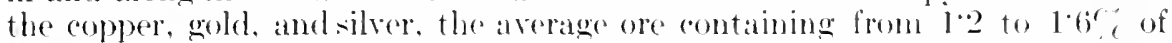
copper, with ahont $\$ 1$ in gold and silver per ton. The important producing mines are located in or near the town of Phoenix, and at Dearlwood, about 4 miles from Circenwood. B.C. The ores are smelted in water-jackoted hlast fumaces, producing a matte that is afterwards treated in hesenemerenverters.

The ore deposits of the coast district are of three distinet types. The Britamnia mines, on Howe sound. are produeing chaleoprevite ores. containing small quantities of gold and silver. These ores oecour in a mineralized shear zone of eonsiderable extent, and are highly siliceous. The development work is very extensive, and there is reason to believe that the deposits will prove to be very large. The ores are eoncentrated and shipped to the Cnited States for treatment. Several mines on Texada island produce bornite, with which is associated more or less chalcopyrite. The ore bodiesocen as a series of lenses in limestones, hut asually more or less elosely associated with certain igneous intrusions. Very important deposits of pyrites, with which is associated chalcoprrite, have been found less than a milo from tide water, near Cranby bay, and about 110 miles from Prince Rupert. Extensive development work, performed during the last three years, has shown that these deposits are very large and preparations are under waty to mine these ores and to treat them in blast furmaces.

Copper sulphides, chicfly chalcopsrite and bornite, oceur at many points along the Pacifie enast and on the aljacent islands. Some prospecting and some development work have been done at a few points and the future will probably witness the development of othere important produreing mines.

There are three copper smelting plants in operation in southern British Columbia. One at Trail treats the ores of the Rositanl camp, producing at

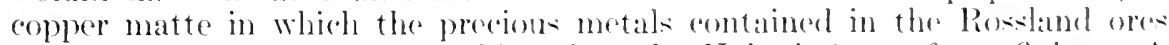
are collected. This matte is shipped to the Tnited states for refining. A very extensive plant, at Grand Forks, B.C .. treats ores derived from Phoenix. in the Boundary distriet, and another at Cirenwoof smelts opes from the Motherlode, and some other mines helonging to the operating company. Both of these plants are equipped with water-jacketed hlast furnaces. and with bessener converters for malking blister copper. () the enat there is a fully-equipped smelting plant, at Ladysmith, on the cast side of landourer islamil, about toi miles north of Victoriat. This is a costom plant, andel at present it is not heing operated. A new plant is also muder construction at Anyox, on Granby lays, and it is expected that it will be in operation in IDecember, 1913. 
All smolting companies in British columbia smelt eustom ores in addition to trating ores from their own mines, and it is probable that the new smelter at lnyox will also atecept colstom work.

The total copper production of British Columbia, in 1912, is estimated at $50,526,656$ pom $1 ;$, valued at $\$ 8,256,561$, New York market average prices for the year.

Gres containing copper have been discovered at a number of points in the Yukon Territory, and one mine, the Pueblo, at Whitehorse, gives promise of hecoming an inceasingly important producer.

\section{Gold.}

Gold, with its mytic influence on man, is usually the first sought mineral in a new comntry. In ('anada, as elsewhere, we find the quest of gold one of the earliest of our industries. In Nova Scotia, in Ontario, and in British Columbia, mining may be said to have commeneed in eamest at nearly the same time, about 1860 , largely due to the influence of the diseoveries in California, From this begiming the industry has grown until the gold produetion of Canala in 1912 was valued at $\$ 12,648,794$, of which $\$ 6,106,677$ Was recovered from alluvial deposits.

For a few years, 1898 to 1904 , due to the Flondike placer output, the production was higher, but otherwise the growth of output has been uniform.

Gold was discorered in Nora seotia in 1858 , but 1862 really marks the beginning of gold mining. Since that date the production has been fairly stealy, averaging about $\$ 400,000$ per ammum. The gold bearing rocks of the provine form a belt rarying in width from 10 to 70 miles and extend some 260 miles in length along the Atlantic coast. In this area the gold occurs in the free state in saddle-shaped guartz reins in many respects similar to those of Bendigo, Australia. At West Gore there is an occurrence of auriferous stibnite. This deposit was worked for some time for the antimony before the presence of the gold was recognized, but in later years it was a fairly steady producer of gold.

The oceurener of alluvial gold in southern Quebec has long been known, the first recorded discovery heing in 1824 on the Gilbert river, a tributary of the ('haudiere, at a point about 50 miles southeast of Quebec city. Mining conmenced in 1847 and operations have been carried on intermittently since. Allurial gold has been found and worked along the valley of the Chaudiere and many of its tributaries from a point some distance below the mouth of the Cilluert river castward almost to the International Boundary.

A small amount of gold also cones from the ores of the Eastern Townships: where prrites and chaleopyrite are found in lenses replacing country rock. These are mined for their eopper and sulphur content, and the gold is recorerent as a by-product.

Though gold has not yet beon discovered in paying quantities in northern Queber, it is by no means improbable that deposits similar to those of Poreufine may he fomd there.

Amongst the various gold bearing distriets of Ontario may be mentioned the eastem Ontario gold belt in Hastings and neighbouring counties, Pary sonnd district, the Porempine and Larder Lake areas, Wanapitei lake, the clistrict north of Lake Huron, Michipieoten, Shebandowan lake, sturgeon lake. and lake of the Moods.

The astern (Ontario gold belt was first exploited in 1866. This district (omprises the southeistern part of Peterborough county and passes through the morthern parts of Hastings, I connox and Adelington, and Frontenar countirs. The gold deposits occur in the older roeks of the Hastings- 
Granville series generally near granite intrusions. There are many small mines in this area which have been intermittently worked sine discovery.

The Poreupine gold area is situated in northern ()ntario, aloout fon miles nerth of Toronto and l20 miles north of the ('obalt silver districet. The most important developments lave taken place in the township of Tisdale, but promising discoveries have also bern made in other townships in the vieinity including Whitney, Ogden, Shaw, Deloro, and Jangmuir. There are also producing properties in Munro and (nubord near Matheson, in Otto at swastika, and in the vieinity of Lareler lake. The oremencence of gold bearing guartz has been known in this district for a number of years, but it was not until the summer of 1909) that diseoveries of importance were mate and interest aroused. Early in 1910 a rush started and around the original discoreries lots were staked for miles regardless of the values they contained. The best looking fincls were tested during 1910 and early in 1911 the construction of several mills was well meler way. Although the first mill only started in July 1912, the gold production from the district for that vear was about $\$ 1,700,000$.

The rocks of the Porcupine area may well be clasied as Pre-Cambrian, and are similat to the older formations oceurring at Cobalt. The gold is associated with quart $z$ in irregular fisures monnge through both the Keewatin and Timiskiming series.

Cold as well as others of the rarer metals is recovered in the refining of the mattes from the suclbury copperenicliel ores.

The mines of western (Gntario embrace a number of classes, lut all ale located in heewatin rocks or in intrusire granites or gneises. Many properties have been worked intermittently though few continuomsly.

In Manitoha some attention is at present being paid to the area lying southeast of Lake Winnipeg and along the Ontario bommdary where some discoveries have recently been made.

Alluvial gold has been fomel in many of the rivers of Alberta, saskatchewan, and the North IVest Territories, though actual production has been limited to a small recovery from the satkatchewan river immediately above and below Edmonton.

About the time simon Fraser, in the first years of the nineteenth centurs, crossed the Rockies to the head of the river now bearing his name, the early settlers of Vancourer island had hegm to realize the wealth of British Colmmbia, and had saled away from Moreshy island, one of the Quecen Charlottes, with a cargo of rich gold ore which paicl them well for their enterprise. lut for some reason they did not repeat the renture. Practically, therefore, the first mineral derelopment is that due to the Fraser River golid rush in 18.58 and sueceeding years, when the Cariben and Quesnel districts were diseovered, followed in is $7+$ by the discovery of endel in Cassiar.

Lode gold mining may be said to have commenced in 1890 with the staking of the Rosistand gold-copper eamp, followed hy the diseovery of the large low grade copperereld ore hodies of the Boundary. These ores, though one of the main sources of the provine es gold produetion, are eomplex gold-silvercopper ores and are mentioned under the head of copper. Practically all the copper ores of the province are aturiforous to a greater or less extent. The Niekel Piate mine at Hedley in the similkamesen is the premier genld mine of the province and its to stamp mill has been a steady producer for a number of rears, its 1911 output being valued at 8679.000.

The ore here is an auriferoms mispickel with varying anounts of copper and iron prrites oecurring in bodies replacing country rock along or near the contact of igneous rocks. 


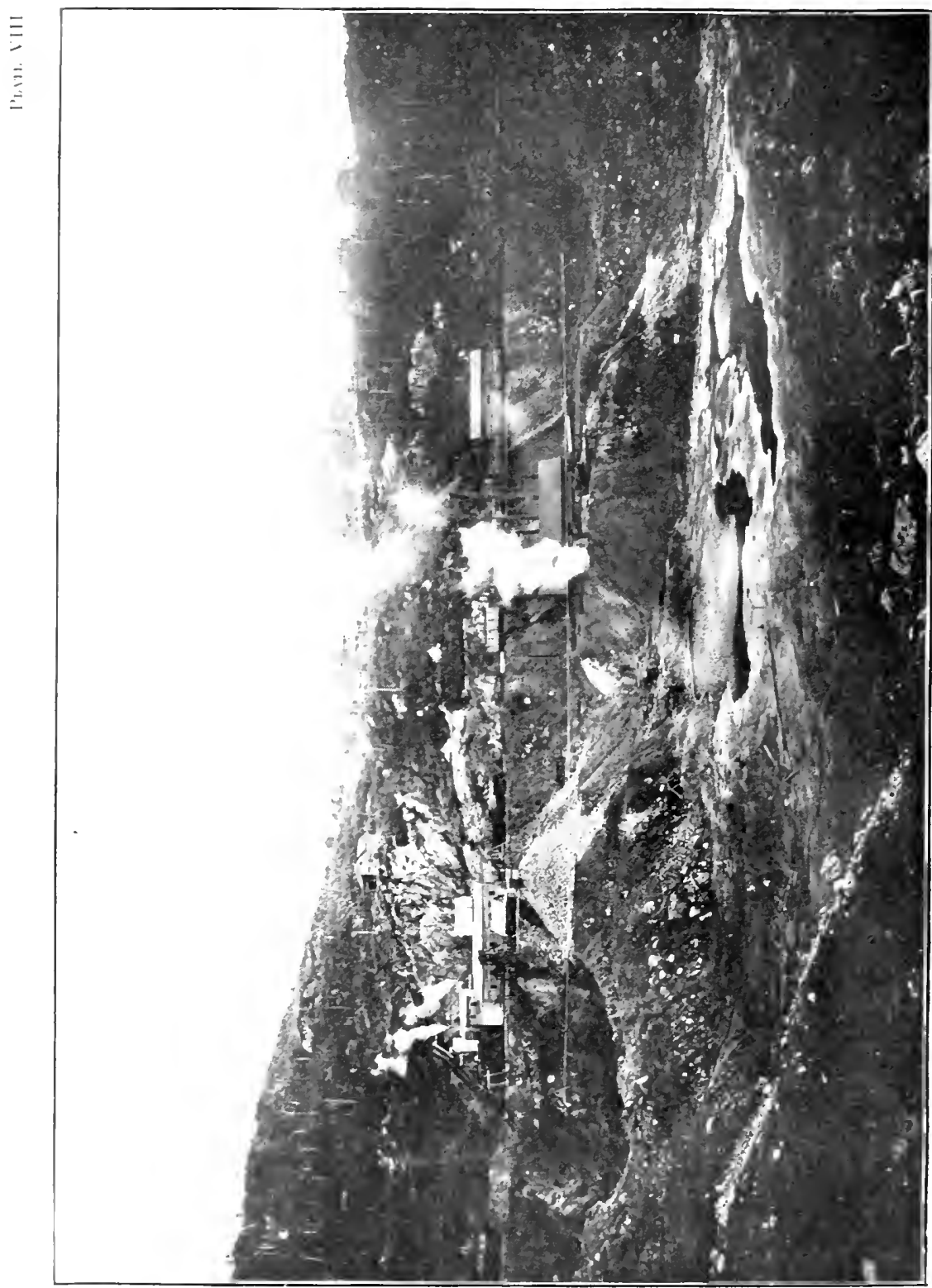

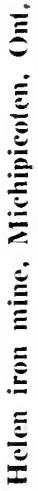




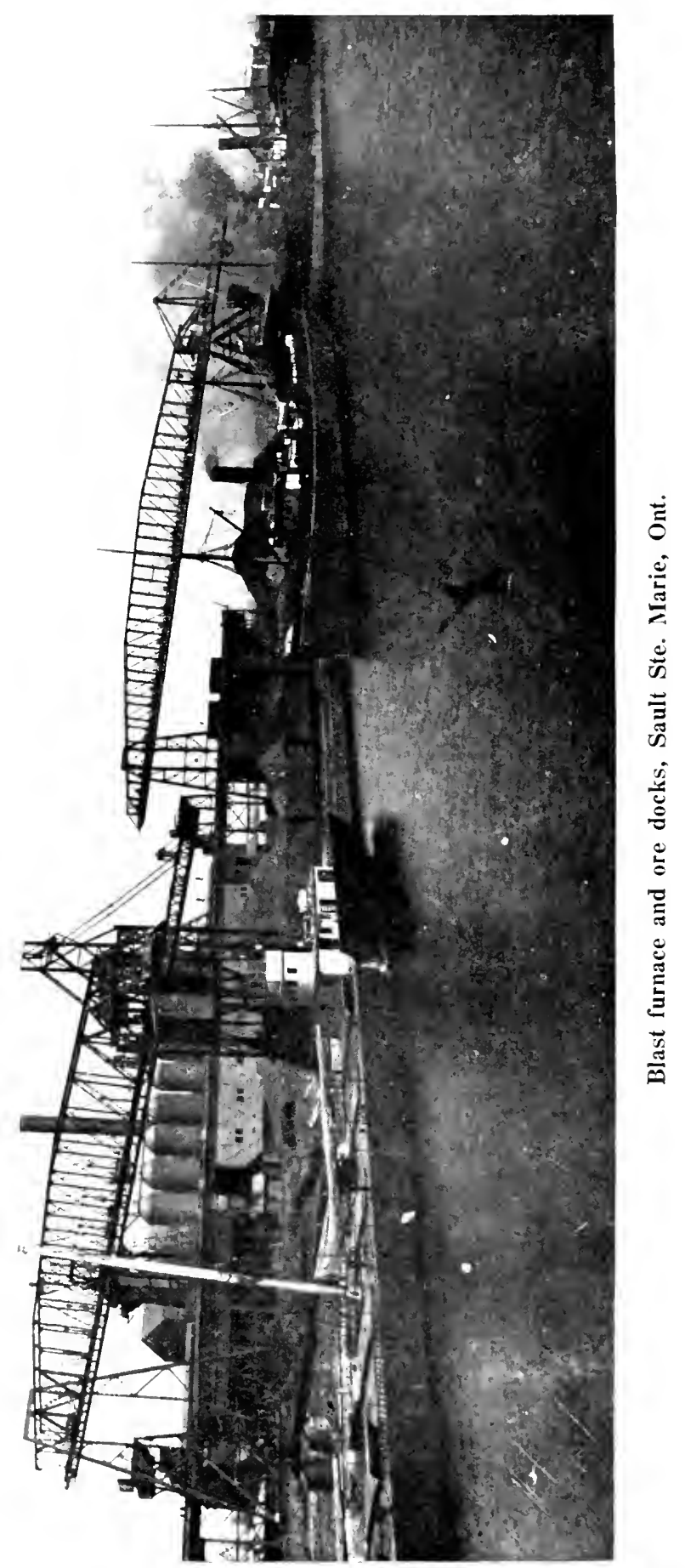


In the Nolson ristrict there are sereral gold properties working, some shipling ore to the smelters, but the larger number stimp milling and shipping the concentrates. Amongst there are the (iranite, nrar Velson, the

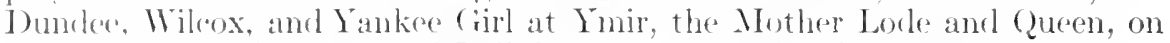

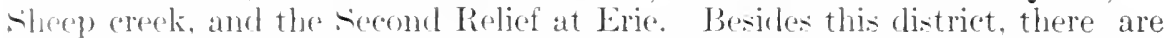
at few gold mines operating in the Lardeau; at Pankon and Carmi, in the Boundary: on Bridge river west of Lillonet: Princess Royal island; Moresby iskind: and on Taku Arm, Atlin lake.

There is still a very considerable production of gold from the placer and hrolranlic properties of the province, the chief centres being the Cariboo district. Quesuel, the Omineca and Atlin, and there is yet much country which is comparatively mexplored. The gold is either in the original pre-glacial gravels or in more recent deposits derived from these.

As early as 18.8 miners began to enter the Yukon and finds were made in various parts of the district from year to year. Discoreries were made on Fortrmile creek, on the Lewes river. and Lper Pelly and Stewart rivers, tributaries of the Yukon, but it was not until 1894 that gold was found on Quartz creek. a tributary of the Indian river. which enters the Yukon above the Klondike river at whose mouth Dawon City now stands. Discoreries followed on Hunker and Bonanza creeks, the latter being especially rich. The news of this discovery resulted in the historic rush of $1897-8$, a stampede which is probably unparallelled in the history of mining. The building of the Whitehorse and Iukon railway from skagway to the foot of the Whitehorse rapids greatly aided the derelopment of the district. The population in 1900 reached 30.000 and the gold prorluction amounted to $\$ 22,275,000$. From that year it decreased annually, having fallen by 1907 to $\$ 3.150,000$. Since that date, owing to the introduction of improved methods and machinery. chiefly large electrically operated gold dredges, the production has again increacol until in 1912 it was 5.5 .599 .296$.

The gold production of the Yukon from 188.5 to December 31. 1912, amounterl to 7.085 .141 fine ounces. valued at $\$ 146.503 .74 \%$. The principal source- of production of the Klondike River area were Tpper and Lower Bonanza. Eldorado, and Hunkrer creek- while on the Indian River slope are Dominion, (rold Run, sulphur, and Quartz. These creeks are estimated by Mr. R. C. MIC Connell to have producerl a total of $\$ 119,000,000$ in gold up to 1907. while he estimated a future production from the Klondike basin alone of $\$ 53.600 .000$

Cold is also recovered at the head waters of the sixtrmile river. south of Dawon. and in the Kluane district in the southwestern part of the Tukon, as well as being widely distributed throughout the territory. Further propecting will probably reveal other gold bearing creeks, some possibly as rich as previous tiscoveries.

Within the last few years increasing attention has been paid to the quartz properties of the district and one mill is now operating near Dawson. The derelopment of lode mines is yet in its infancy but promises well for the fut ure.

\section{Iron.}

Although iron ores are willely distrihuted in canada. the present extensive metallurgical industry in iron and steel has been developed to a very barer extent on the hasis of imported ores. chiefly the conveniently situated and comparatively releaply mined ores of Bell island, Newfoundland, and ores from the irem ringes on the south shore of Lake superior. There are. nurertheless. a mumber of important iron ore deposits that have already rontributerl consideralile outputs in the gast, and there are numerous occur- 
rences which in the future mat anstitute valuahle sourese of supply for this metal.

In the proviuce of Nova siotia the principal iron ore deposits are those at Clementsport, Nictanx, and Torbook in Annapolis county; Brookfied and

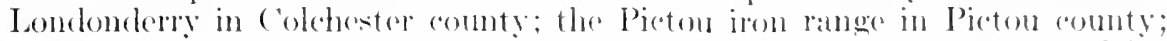
and Thyeocomalgh in Invermess county. A wisk variety of ore is found ineluling hematites, magmetite, bog ore, limonite, and carbonates.

The Nictaux and Torbmen field is practically the only one being actively exploited at the present time. Formerly this, together with the Londonderry and Pietou deposits. produced considerable guantities of ore which were smelted at Londonderry, Pietou, and Xew (ilaswow. For a number of vears past blast furnace operations hatre been transfored entirely to sigdney and North Fyedney, ('ape Breton, where laree and extensive plants latwe been ereeted by the Dominion Iron and stecl company and the Nova sirotia siteel and Coal Co.

These two plants include blast furnaces with a total daily capacity of about 1700 tons. Coking plants with by-product recoveries. Bessemer convertors and open hearth fumaces, steel finishing mills for billets, rails, rods, wire nails, bolts and nuts, ete. The Nova Seotia steel and Coal Co. has an extensive steel plant at New Giasow. Both companies own or control their own collieries near sydney and limestone quarries comveniontly situated. They own and operate their iron mines on Bell island. Newfomdland, the ore from which not only supplies all demands at sirlney, but is shipped to the United states and Europe.

Iron ores are found in the province of Xew Brunswick in Carleton county near Woodstock. These ores were utilized in blast furnace operations at Woodstock begum in 1848, and carried on at intervals for 20 vears thereafter. Other occurrences of iron have been noted at Wost Beach and Black river on the Bay of Fundy, near st. John, and also in ('harlotte county, near Lepreau. The most inportant deposits howerer, yet found in this province are those in the township of Bathurst, county of Ciloneester. One of these, the Nipisiguit deposit consisting chiefly of mianetite, was diseovered in 1902 , and has since been actively developed." shipments of ore have been made to the Lnited states and to Circat Britain. It serms rearomable to experet that in the future other deposits of iron ore may be located orer a eonsiderable extent of territory in this district.

Along the north shore of the Sit. Lawrence river in the provinee of Quehee, beds of magnetite have heen reported at many points. The ore is found in two forms, viz., as massive deposits interstratified with the gneiss and linestone of Laurentian or as beds of iron sands along the beaches often in considerable thickness and of great extent. These ores, while carring a large percentage of magnetic oxisk of iron also frequently entain a considerable amount of titanic acid, in fact during the past few years sereral thousand tons have been shipped for the titanimm content.

Deposits of immenite or titaniferous iron ore also oecur north of Montreal at St. Jerome, St. Lin, Irry, and other points.

In the townships of Leeds, Inverness, South Ham, and Aseot, sereral small deposits of magnetite are known to oceur, but they have not as yet been proved to be of commercial importance.

Limonite or bog iron ores have heen mined for 180 years in the sit. Franeis River distriet, east of the st. Lawrenee, and the st. Miturice river to the west. Small furnares have been in fairly eontinuous operation at Drummondville and Radnor Forges and the produet has been an exeellent quality of ehareoal pig iron. 
Magnetite ores have also been found in the townships of Grenville, Templeton, Hull, and Bristol, some of which have been worked to a considerable extent in past years.

As carly as the year 1800 attempts were made to smelt iron ores in Ontario and between that date and 1883 several enterprises were started only one of which was successful. This was the furnace at Normandale in Norfolk county, now long since abandoned, where the bog ores of the vicinity were smelted with charcoal as fuel.

In eastern Ontario, chiefly in the counties of Hastings, Frontenac, and Renfrew, and served by the Central Ontario railway and the Kingston and Pembroke railway, numerous deposits of iron ore, both hematites and magnetites, are found. Some of these such as those in the township of Mayo, are of considerable extent. Many have been opened up and several hundred thousand tons were shipped to smelters in the United States and Canada.

In the northern portion of the province active mining operations are at present being carried on at Moose mountain, 20 miles north of Subdury, at the Helen mine near Michipicoten, northwest of Sault Ste. Marie, and at the Atikokan range west of Port Arthur. The Moose Mountain deposit situated in the township of Hutton is a large and important deposit of magnetite, there are in fact several deposits constituting what is known as the Moose Mountain range. Shipments are being made by way of the Canadian Torthern railway and Key harbour on Georgian bay.

The Helen mine in the Michipicoten range is the largest iron ore producer in Canada, the output approaching 1,000 tons per day. The deposit is some 1,400 feet long with an average width of 400 feet. The ore produced is of three grades, hematite-hard and compact, containing 60 per cent or over, hard brown limonite and hematite, 57 to 55 per cent iron, and soft brown limonite containing 53 to 54 per cent iron. The ore is shipped by rail to Michipicoten harbour and thence by boat to the smelters at Sault Ste. Marie, Midland, Hamilton, or the United States market. A number of other deposits in the same vicinity are being developed.

The Atikokan range is situated along the Atikokan river, 140 miles west of Port Arthur on the Canadian Northern railway. Outcrops have been traced for a distance of nearly 12 miles but prospecting has been carried on chicfly in the ricinity of Sabawe lake. The ore from this range is used in the blast furnace at Port Arthur.

In addition to the iron deposits being actively operated, there are in northern Ontario a number of known iron ranges some of which may prove to be valuable ore reserves. About 26 miles east of Port Arthur in the ricinity of Loon lake, is an iron range which has aheady attracted considerable attention. The ore consists mainly of hematite but is mixed with a great deal of lean material. The Mattawin range is situated in the district of Thunder Bay about 48 miles west of Port Arthur and follows the Mattawin river for a distance of about 4 miles. The ore consists of alternate bands of jasper and magnetite, and is low grade and siliceous and would require concentrating.

East of Lake Nipigon is an iron formation known as the Lake Nipigon range. The iron bearing rocks are here divisible into three ranges called the Northern, Southern, and Middle ranges. The ore is magnetite or hematite associated with jasper. No commercial ore bodies have been found as yet.

In the district of Nipissing the Timagami and other ranges, have attracted considerable attention but remain practically unexplored. 
These are but a fow of the known ocourreneese of iron in ()utario, In

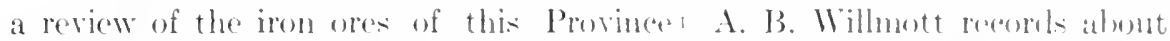

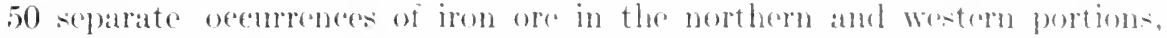

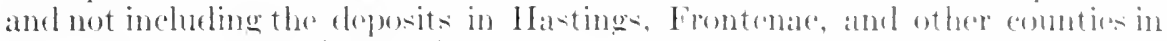
the easterm part of the provinee.

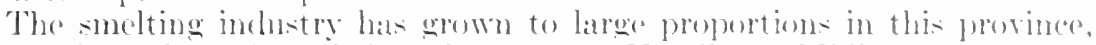
furnaces have been installed at Deseronto, Hamilon, Midland, and siant

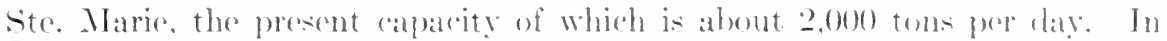
adelition to these a new lumber is muler construction at loort collorme, and the Enited sitates sted corporation is making preparations for the erection of a large plant near siandwich. It Hamilton ame sialut ste. Marie there are large and woll explupped stoed plants and rolling mills producing hatrs, stool rails, anel othere sted products.

The prairie provinees of Manitobla. Saskatehewan, and Alherta have as vet furnished no proshation of irom. but there are a mumber of known oceurrences of hematite, limonite, and ray iron stone.

In the province of British columbia, some iron ore has heen mined on

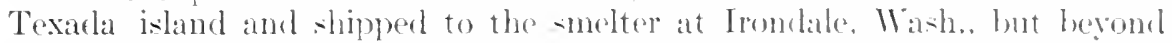
this the iron industry of the provine maty he sidel to ho as yot undereloped. A number of occurrences of iron orre chiefly magnetite have been noterl on Vaneouver islanel. These, so far as olserved, on the coast, are wsually found on the end or flank of a ridge following roughly the contours of the liths and occur almost always alone and aljareent to the contact of limestone and some eruptive rock. Among those that have attracted at tention might be mentioned the properties at Head bas, Klanch river, Quinsm river, and fordon river on Vancower island, and the Texald Island ores already mentioned. In the interior of the provine oceurrences of iron have been noted at Kannloops, Kitchener, Bull Run. Bumis, and alsewhere, hut no mining has been elone on any of these deposits with the exception of at small shipment of ore as a flux from the ('herry Bluff mine near Kimloops.

The total production of pig iron in C'mata in 1912 was 1.014.58\% short tons and of steel ingots and casting: 957.681 short tons. That the domestic production is insuffieient to meet home demands is indicated hy the large imports which in 1912 exceeded 1.300.000 toms of pig iron, ingots, blooms, etc., plates, bars and rods, structural steel, rails, pipe, nails, wire forgings, castings, etc. The opportunity in so far as the market is concerned for the development of Canadian iron resources is evident.

\section{Lead.}

In Canada lead is derived entirely from galena ores the creat majority of which are argentiferous and therefore much that is sald of silver is applicable to lead and similarly on arecomt of associated blende much that is said of lead covers the ground in connexion with zinc.

In Nova seotia areentiferous galena ores have been worked nour Musquodoboit in (ape Breton county in the Pre-Cambrian rocks. They also occur at various points in the lower ("arboniferoms limestones.

Veins of galena are found in the Silurian roeks of New Brunswek and have been foumd at varions points through the Eastern Townships, in (iaspes, in Portneuf county, and on Calumet island, where they have been worked to some extent.

${ }^{1}$ The Iron Ores of Ontario, A. B. Willmott. Journal of the Camadian Mining Institute, Vol. XI. p. 10 s. 


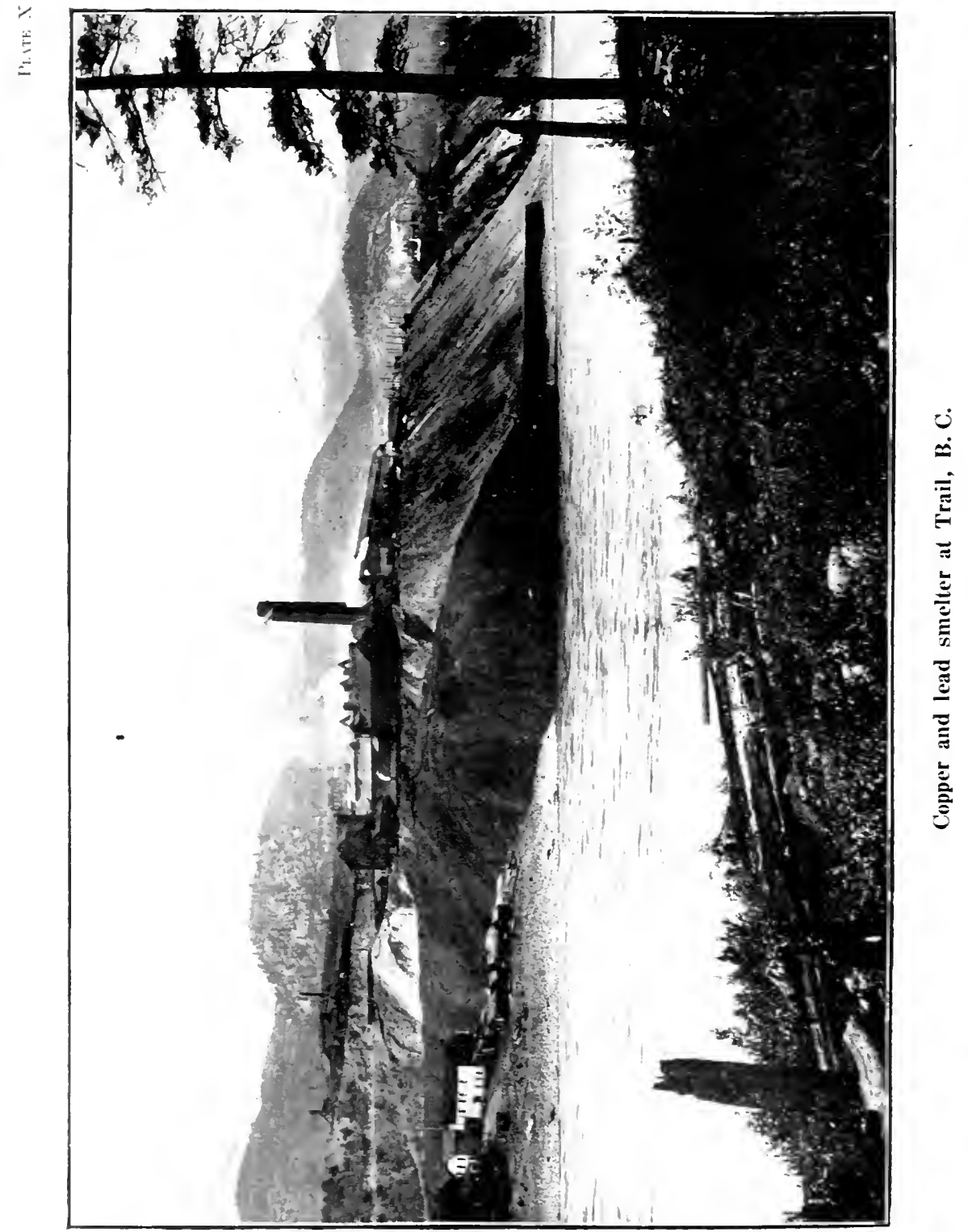



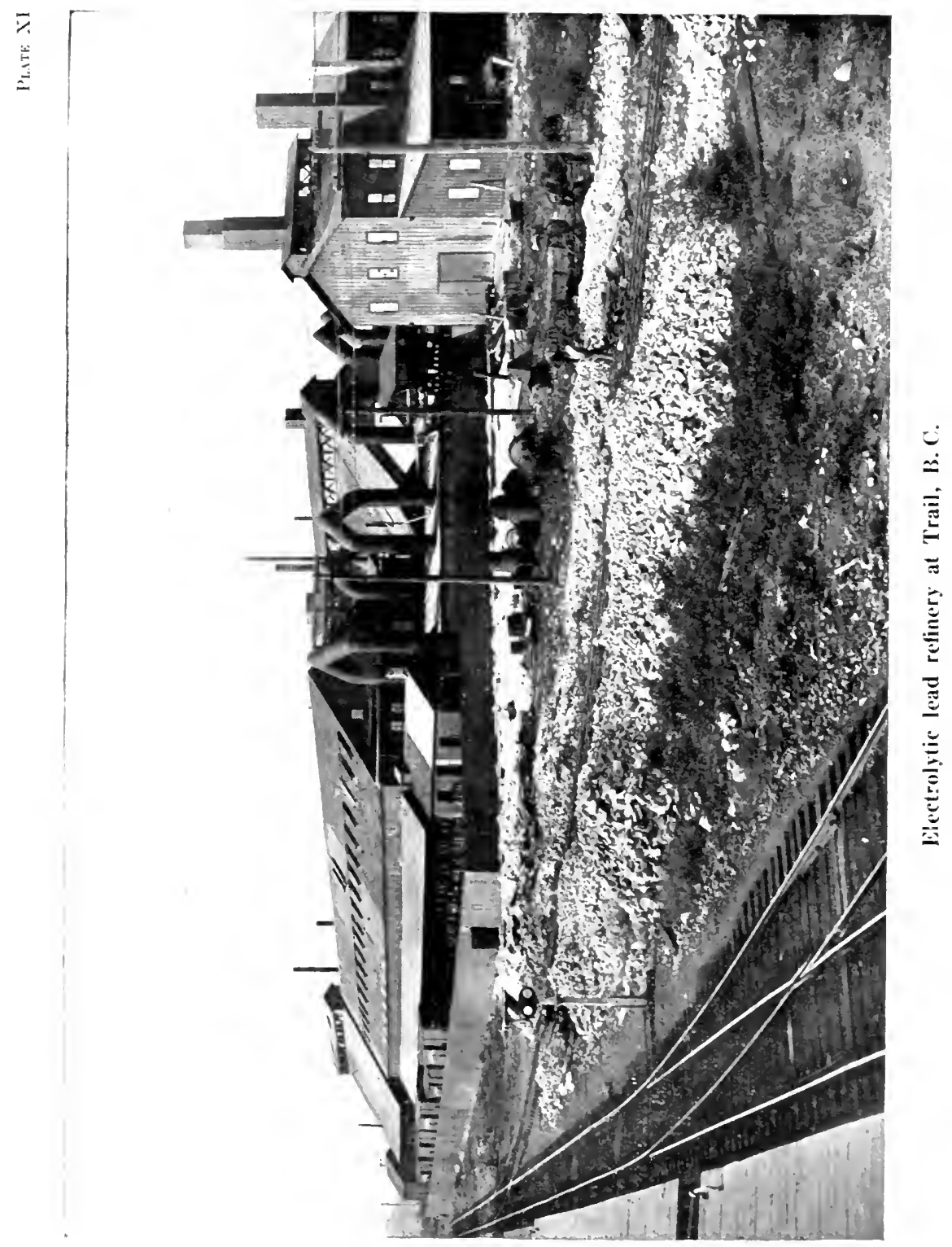
In Ontario the Frontenac lead mine was opened about 1868 and a smelter was erected in 1879; operations however coased in 1882. Tarions properties have been worked fiom time to time, and the Frontenac is once more being operated. The ores are galena carrying little siber.

A learl smelter, that of the North Ameriean Smelting Co., is in operation at Kingston, trating Ontario, United States, and British Columbia ores.

Practically all the lead produced in (anada in recent years has come from the British Columbia silver bearing galena ores. The Blue Bell mine was discovered in 1825 but active opcrations in the Ainsworth camp date from about 1888, with Sanclon canp following in 1892 and the discovery of the North Star, St. Engene, and Sullivan in East Kootanay in that year and the next. The latter are large bodies, romparatively low in silver eontent, the St. Eugene ore being argentiferous galena with some zine blende and a little pyrite forming irregular lenses in a fissured zone within Pre-Cambrian quartzites.

There are a few producing mines in the sheep Creek district, south of Nelson, but the largest number of mines are located in the Ainsworth and sloean districts. The sandon-silverton camps especially are showing promise, development at depth having been very satisfactory. The ores are argentiferous galena and tetrahedrite with native silver and sometimes gold, argentite, zine blende, ete, in veins eutting secliments. The ores of the Jardean may be said to belong rather to the silver ores than to the lead, and the same may be said of the Greenwood camp. The West Fork of the Kettle river will probably add some shippers to the list with the opening of traffic on the Kettle Valley railway, and the Canadian Northem railway may provicle shipping facilities for the silver-lead properties of the North Thompson River valley'

West of Princeton in the Similkameen, at Leadville, a new camp is opening up but no shipments have yet been made. On the coast, Portland Canal district is another silver-lead cimp, and the newer discoveries toward the Bear river are most promising.

The present year will see shipments from several mines in the neighbourhood of Hazelton on the skeena river. Development has been going on quietly for several years awaiting the advent of transportation, with the result that the eamp staits shipments with a fair anount of clevelopment done.

The lead ores of British Columbia are nearly all shipped to the smelter of the Consolidated Mining \& Smelting Co., at Trail, which operates in connexion therewith an electrolytic lead refinery, the products of which are refined gold, silver, and lead, copper sulphate, and antimony.

A few of the Coast ores find their way to American smelters.

In the Yukon there are several properties which have been developed and have shipped occasionally, but in most eases as yet the transportation charges have been found too heary a burden. With further development of the country these will probably become shippers.

As mentioned elsewhere the prospects of finding more lead ore bearing areas throughout Canada and especially in the more remote districts are most favourable, and many districts now known only await transportation facilities.

\section{Molybdenum.}

This mincral oceurs as molybdenite or molybdite, and although found in muncens localities in many parts of the comntry, there has as yet been practically no recovery of the metal in Canada with the exception of small amounts obtained while developing or exploring properties. With regard to the loca- 
tion of molybdenite deposits. I)1. T. L. Walker, in his sperial report o on this subject, states that in cimalda they are ustually fomd in the Arehetam

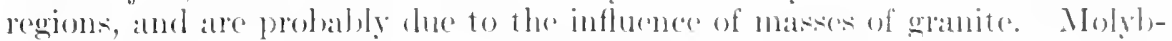

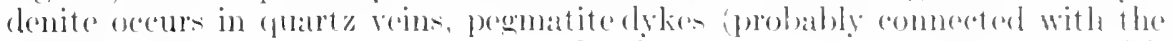
granite masses), and alome contaret horiders of granite or peomatite with erystalline limestone.

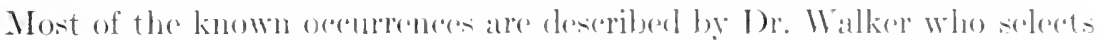
the following list as representing the most promising deposits at they wore to be seen in 1909 and 1910: istand oppesite Romaine, lower st. Lawrener; Alelfield and Egan townships, nortli of the Ottawa river. Deposits in the vicinity of Kewangma lake in the northern part of Pontiac combly, (2ue., near the Grand Trunk Pareific railway; Brougham, Lyndoch, and foses townships in Renfrew county, Sheffield township, Adelineton county, and (andilf township, Haliburton county, in castern Ontario; and the Giant minc, Rossland, B.C.

\section{Nickel.}

Mincrals containing nickel hare been foume in a number of localitios throughout Canalat, but the important commercial deposits at present exploited are eonfined to two localitien, both in the provines of ()ntario. Thase are the Cobalt and subclury districts. It should he mentioned, in passing, that pyrrhotites carrying a small anount of nickel are known to ocear near sit. Stephen, New Brumsick, amel also in sereral other localities in Ontario. Similar occursenees have been reported from British ('olumbia. These, however, are comparatively low in grade and have not been surecessfully exploited.

In the Cobalt clistrict nicolite, an arsenide of nickel, oceurs either alone or associated with other less important nickel-bearing minerals in the reins in which the native silver and silver-hearing minerals are found. The arorage percentage of nickel in the ores shipped from Cobalt varies considerably for the different mines. For the whole distriet the average is probably betwen 3 and 5 per cent. The total tomage is very small and only a portion of the nickel is recovered as the oxide.

The Sudbury nickel region has sharply defined geological boundaries, since all the ore deposits are connected with a single great sheet of eruptive rock, called norite. This sheet is roughly boat-shaped, with a blunt bow turned towards the southwest and a square stern towards the northeast. The sheet is basin-shaped, its interior is filled with sedimentary rocks and only the upturned edges are exposed. The basin is 36 miles in length, from southwest to northeast, and 16 miles in width. All the known ore depositsoenen either along the alge of the sheret, or less than 4 miles away from it, on projections or "offects." In the early days the nickel deposits were grouped in two ranges-a main, or southem. range, and a northerm range, hut sinco it has been proved that the ores are all comnected with the edges of a single sheet of eruptive rock, one may think of them all as belonging to a single oral range. It is found that the important deposits are not distributed uniformly around the basin, but that there are rich portions separated by baren portions. It is probable that in the near future a thirel, or castorn, range will be recognized, and possibly a fourth, or western range, thougl at present the ore deposits at the west end are not known to be of much importance.

${ }^{1}$ Report on the Molyblenum Ores of Canada, by T. I. Walker, I'h.D. Mines Branch, Dept. of Mines, Ottawa, 1911. 


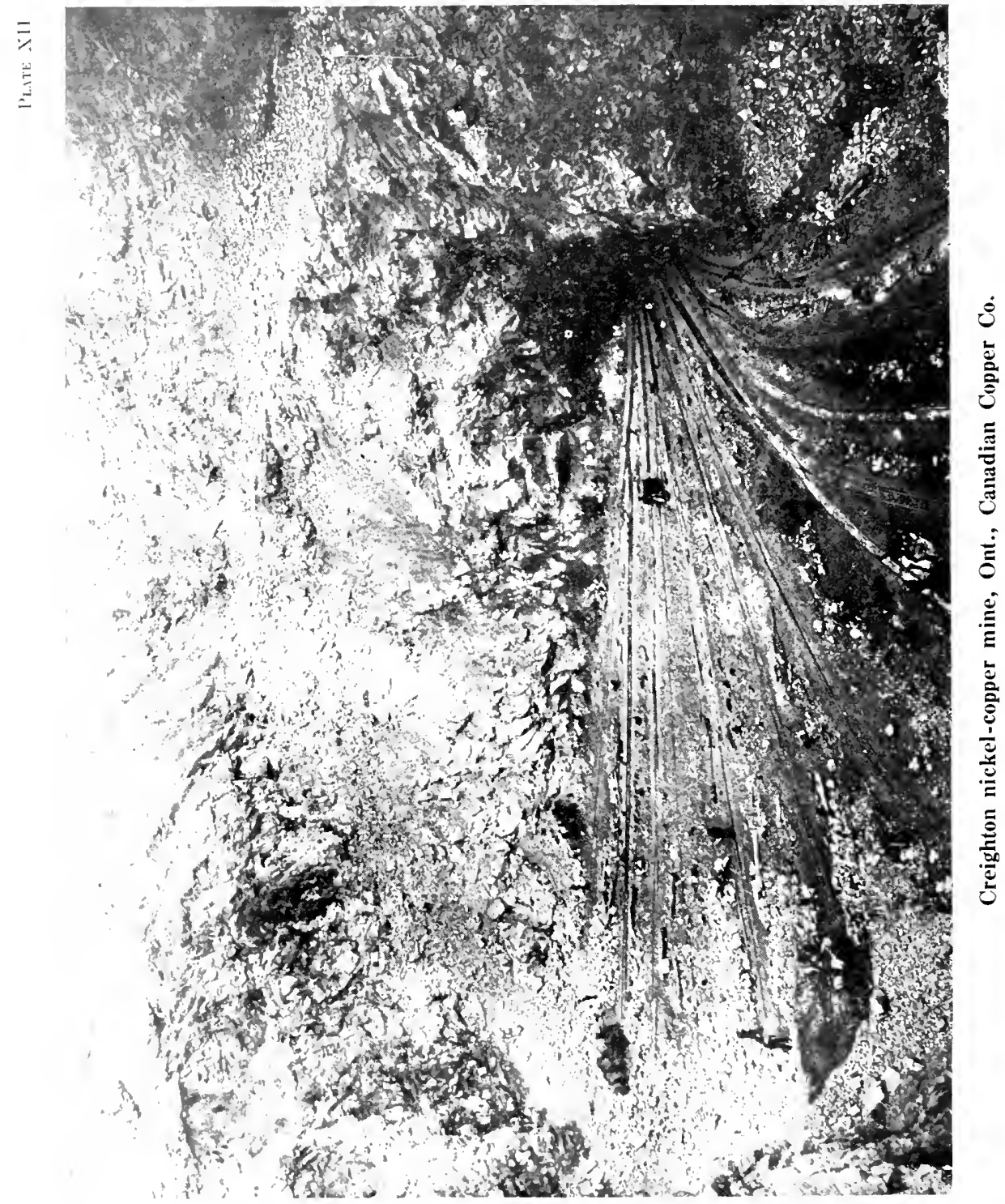


At present, the main nickel range may be dofined as running from the Sultana mine, 6 miles southeast, to the Viedoria mine, then turning northeast for 23 miles to the sheppard mine, and finally east for 4 miles to the Ciarson mine. There is. however, a gap of about is nules towards the southeast, between the crean Hill and Gertrude mines. where no ore has been found. Along this somewhat irregular line of 33 miles on the southern margin of the nickel-bearing eruptive, 17 mines have producesl ore, and within 2 or 3 miles to the south of it, 10 other mines have been workerl.

Practically all the ore hitherto mined and smelted in the regionmust be credited to the southern range. The northern range is not so eontinuous as the southern, hut is generally reckoned as extending from certain deposits in Levack township to the Whistle mine at the northeast corner of the basin, a distance of 25 miles. There are, however, two gaps of 6 miles each, so that there are only 13 miles of the margin of the nickel eruptive which are ore-bearing. In addition, howerer, some ore has been found for 6 miles west along an offset.

Coleman recognizes two main varieties, or trpes, of ore bodies in the region, which he designates as "marginal "and "offset "deposits.

Many of the more important nickel deposits occul at the basic margin of the norite, lying between it and the adjoining combtry rock. They are commonly irregular sheets of ore, oceupying the lowest parts of the country rock, penetrating all its fistures and enclosing blocks of it of all shapes and sizes. They may, howerer. have a very distinct foot wall, where the country rock was not shattered by the influx of ore and norite, or where faulting has brought a smooth surface of eountry rock against the ore. Pasing upward through a rarying thickness of pure ore containing very little of the rock minerals, the blending of rock and ore. called pyrthotite-norite, ocentr, passing finally into norite with a few blebs of ore. The inner and upper marwin is very indefinite. being fixed in mining simply hy commercial consilerations. The thickness of workable ore may rary from it fow feet to 100 fret, or more: the length is eoually ariable, ranging from 100 feet or 200 feet to 700 feet. The depth to which marginal deposits go is unknown. The creighton has heen explored hy mining to 700 foet and diamond drilling hats shown that it extends to at leatst 900 feet.

The "off-set" deposits of Coleman include ore bodies connected with dyke-like projections from the basie edge of the norite, or more or less separate masses of ore and norite not risibly comnected with the main borly of rock, hut alnost certainly having underground connexions. Typioal offsot doposits differ completely from the marginal deposits. They are often more or less columnar in shape, forming pipr-like ore bodies. The contents of these pipelike bodies differ eonsideral,ly from those of the matrinal deposits, being more rocky, and containing usually more copper ore, as well at more of the precious metals: gold, silver, platimum, and palladium. Another type of offeret, with rery different features from the colummar type, is recognized in the Frooststobie offect, which contains the greatest mass of nickel ore thus far discorered in the district, or in the world. In this ase there is no observable connexion with the hasic norite edge. The offset, howerer, lics parallel to the edge and at a distance varying from 4,000 feet to 8,000 feet to the southeast. The ore resembles that of a marginal deposit more than that of the columnar offsets, and the ore body dips at an angle of $60^{\circ}$ towards the basic edge. It is a long irregular sheet, enclosing much rock, and its connexion with the edge of the norite is probably at a considerable clepth bolow the surface. The ore is known by diamond drilling to extend northwest beneath 
the comntry rocks to a depth of more than 1,000 feet. This deposit probably (ontains over 35.5000 .000 tons of ore.

The nickel-bearing minerals that hare been reported from the Sudbury region are jyrrhotite, pyrite, marcasite, pentlandite, polydymite, gersdorffite, millerite, and nickelite. (of these, pyrrhotite and pentlandite are the only ones having any important relation to the ore deposits, and the former is the only one visibly present in all the ore deposits. There is some cloubt, howerer, as to whether prrrhotite is nickel-bearing in itself, since its nickel content nity be due to finely diseminated pentlandite. In addition to the sulphides containing nickel and iron, a sulphide of copper and iron, in the form of chalcoprite, is almost invariably present. It comes next in amount to wrrhotite and pentlandite and is always a more conspicuous component of the ore, becance of its colour. Copper prrites may be either intimately mixed with the pyrrhotite or form considerable masses by itself. It is especially common near the walls of ore bodies or associated with masses of rock encloser in the sulphides, so that, as a rule, rock ore contains a higher per"entage of copper than or rich in sulphides. In two important minesthe Copper C'liff and Crean Hill-copper is present in larger amounts than nickel. and at Garson and Victoria mines it about equals the nickel; but all the other mines contain more nickel than copper.

The metallic content of the ores varies considerably in the different mines. The nickel content reported averages about $2 \cdot 09 \mathrm{C}_{\mathrm{C}}$ and the copper $1.85 \%$. If the losos in roasting and smelting are assumed to be $15 \%$ of the metallic contents. the proportions of metals in the ores will be $3 \cdot 09$ of nickel and $2 \cdot 12$ of (opper. making a total of $5 \cdot 21$ per cent. The ores also contain small amounts of the precious metals, including platinum and palladium.

The metallurgy of the suclbury ores includes four distinct processes:-

Roasting of the ores in open heaps, to remove part of the sulphur.

smelting in water-jacketed blast furnaces, to produce a low grade matte, containing about 33 per cent copper-nickel and nearly all the precious metals.

Convorting the furnace matte in Bessemer basic converters, to make a matte containing about 80 per cent copper-nickel.

Refining the converter matte, separating the nickel, copper, and precious metals.

At the present time, the first three processes are carried on in Canada in the sudbury district. The converter matte, however, is shipped either to the Enited states or to England for final treatment in the refineries.

The most promising recent find of nickel ore in Canada, aside from the cudbury deposits, is the Alexo mine in northern Ontario, near the town of Matheson. This deposit consists of prrrhotite, containing nickel, associated with chalcopyite in a serpentine rock, the latter having been formed by the alteration of a peridotite. This occurrence of ore is similar to the Sudbury leposits. Mining operations are in progress and a small amount of ore has alrumly been shipped to the smelter at Copper Cliff.

There are two strong companies carrving on mining and smelting operations in the sudbury nickel region. A third company has recently acquired propertics containing great reserves of ore, and is plaming the erection of an rxtensive plant.

The total production of nickel (contained in matte) in 1912 was $4+, 8+1,5+2$ pounds, valued on the basis of refined metal at $\$ 13,452.463$. There was also it recorery from the same ores of $22,231,725$ pounds of copper, valued at 5.3532 .586 . on the basis of the New York market average price of copper for the rear. 


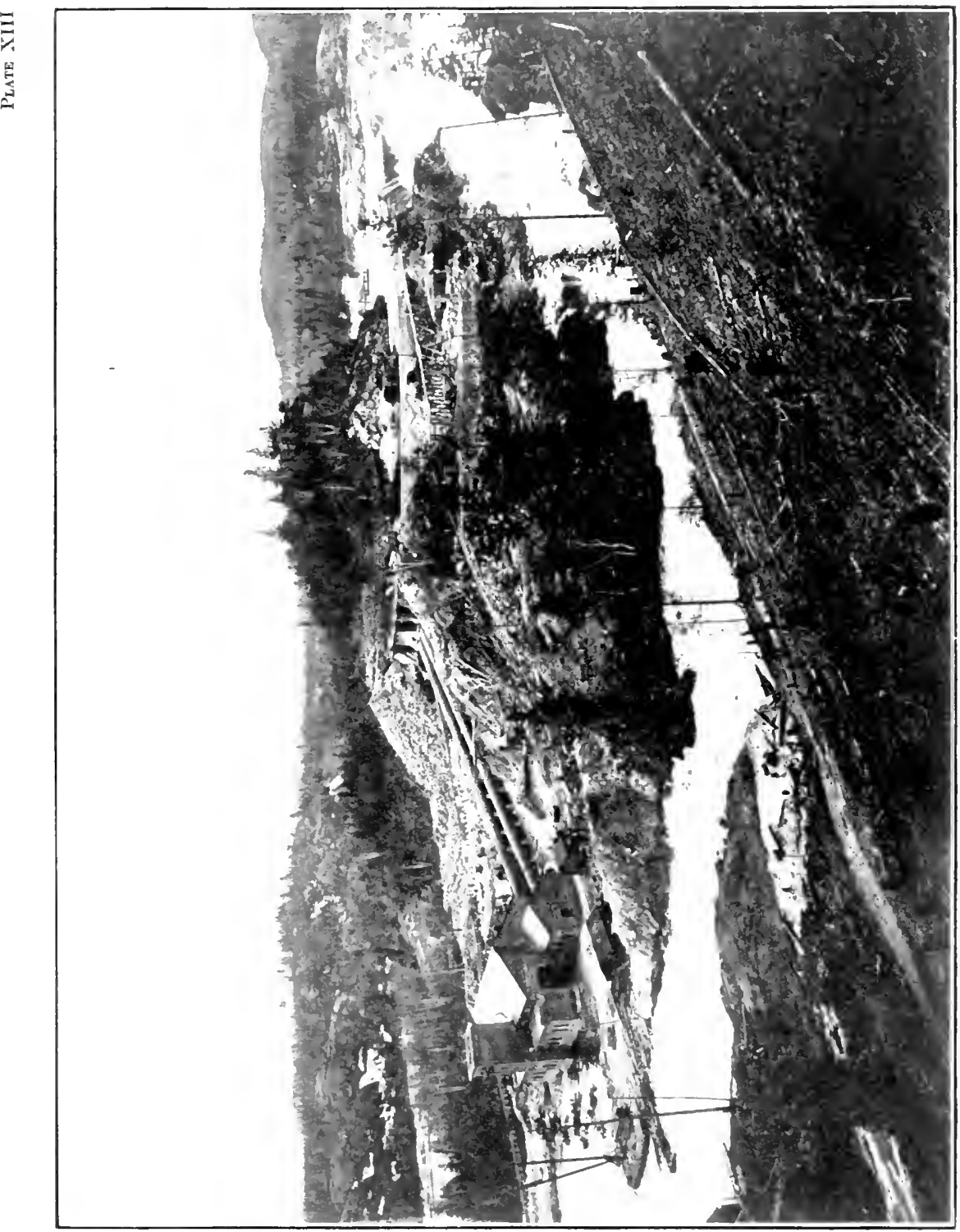

نे 
Platinum, Palladium, etc.

Both platimum and pallaclium orem as constituents of the nickel-copper ores of the sulloury district in (Ontario, though in very small amounts. After smolting the ores to a Bessemer matte containing afout 80 per cent of the combined motals nickel and copper, it is found that this matte contains from 0.17 to $0 \% 5 \%$ of the platinum metals per ton, the proportions varying with the ores from different mines. The preeious metals are recovered from the resilues remaining after the treatment of the mattes for niekel and eopper.

Platinum has also been found in many of the gold placer deposits, its occurrence in this mammer having been noted on the Riviere du Loup, Quebec, on the Similkinneen, Tulameen, Tranquille, Fraser, North Thompson, and other creeks and rivers of British Columbia, on the Yukon and its tributaries, and the Treslin and other rivers of the Yukon clistriet.

\section{Silver.}

The silver produced in Canada at the present time is derived from three main soures, the silver-cobalt-niekel ores of the Cobalt district, Ontario, the argentiferous galena of British Columbia, and the recovery at the smelters from the complex gold-silver-eopper ores of the different provinces. There is also a slight reeovery from gold mill bullion and from placer gold.

In Nova scotia there are some argentiferous galena deposits near East Bay and Musquodoboit, Cape Breton, which have been intermittently worked.

Champlain mentions a galena property on Lake Timiskaming, Quebee; this was afterwards known as the Wright mine, and was worked for some time. At Calumet island there are several silver bearing galena deposits which have been worked at various times.

A small amount of silver is also eontained in the copper sulphide ores of the Eastern Townships, and whilst, as yot, no discoveries have been made, it is by no means improbable that areas similar to Cobalt distriet may yet be found in this provinee.

In Ontario, as carly at 18t6, veins earring silver were found on the shores of Lake Superior in the distriet about Port Arthur, and from 1866 to 1903 the district produced silver. The most famous silver mine was known as the vilver Islet and the rein was found on a small island, some 90 feet square, lying noar Thunder cape. The ore bearing veins of quartz and carbonates traversed a large dyke of diabase entting it along a fault plane. Only where the rein traversed the diabase, did it carry silver, elsewhere except gangue material, it bore only galena, sparingly disseminated. When the mine was abandoned in 1884 , work had been carried to a depth of 1,160 feet, and it is estimaterl that $\$ 3,250,000$ of silver had been extraeted.

The position that Canada now holds as a silver produeers country, being thim on the world's list of silver producer's, must be credited in large measure to the mines of the Cobalt distriet.

Cohalt, situated on the main line of Ontario's government railway, 330 miles north of Torouto, has the mines closely clustered round and eren beneath the town, while other are distributed in a southeasterly direction for at distanere of $t$ miles. This comprises the Cobalt silver distriet proper, and while isolated productive mines have been found in the outlying eountry, such as the (ascy, 19 miles north of Cobalt, the Wettauffer, 20 miles south, and the Millerett and Miller-Iake O'Brien, 50 miles northwest, nevertheless nonc of these newer discoveries have ret disclosed a distriet eomparable to the parent ('annj). 


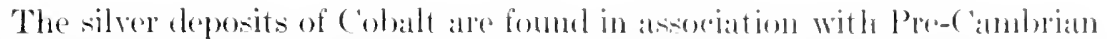
rocks. These belong to the Huronian and lieswatin formations and through them has been introdued a later cliabase in the forme of a sill. This intrusive

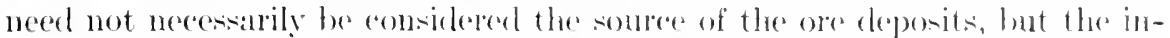
dications are that it was the nowas of opening up the waty for their introduction from other adjacent seneres. About so pere eent of the productire veins oceur in the Huronian formation, while the remaining 20 pere cent is alout evenly divided between the Keewatin and the later diabase. As a rule the Cobalt silver deposits are not known to extend to great depths. Brew the sill most of the silver is fomel within a deptle of 200 leect.

The Beaver which is above the diahase hats the derenest workings in ore in the district, having attained a depth of 700 feet. To offied this shallowness of the ore, the salvation of the camp seens to lie in the fact that the veins are mumerous. The reins are appoximately perpendieular and rary in width from a mere crack up to 12 inches or more occasionally. The values are not confined to the rein rock itself, but in many cases extend into the adjacent wall rock, making a raluable milling ore. In exceptional cases this disseminated ore has a stoping width of 15 feet and from is to 6 feet is not uncommon. The vein filling is usually ealeite or dolomite arring native silver associated with the arsenides of colbalt and nickel. A trace of gold is found in the ores as well ass a small anount of mereury, and in 1912 one of the mines was paid for a small copper content.

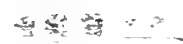

There are in Ontario six smedters for the treatment of ores from the Cobalt district. The produets from these incluele. fine silver, white arsenic, colnalt oxide, nickel oxide, and in some cases as somi-refined mixture of the cobalt and nickel oxides.

From the copper-nicke! ores of the simbury distriet silver is besing recovered in the rofining of the matte.

The silver production of British Columbia comes mainly from the argentiferous galena ores of the proviner which will be more fully described in the chapter on lear. In the Eant Kootenay the ore boxlies are large and the silver content low, and the sime may be said of the ore boedies in the sheep Creek division of IVest Kootenay and the Bhor I3ell mine on the east shore of Kootenay lake. The ores of the slocan distriet ane mueh higher in silver, probably averaging 75 oz. per ton of ore, whilst the ores of the slocan City and the Lardean divisions are what aro known as dry ores, eontaining littlo galena, the values being in native silver and somotimes a little gold associated with argentite, prargyrite, tetrahedrite. ate.

A few galena and high grade deposits are heing worked in the Bombary district, notably near Greenwood, and the completion of the Canadian Northem may see shipments from the North Thompson River valley.

In the neighbourhood of Hazelton on the Skeena, a number of new properties are just entering the shipping list. The ore in galena carying gold values in silver.

As mentioned before there is a considerable amount of silver recovered from the gold and gold-eopper oresand alluvial gold production of the province. These are more fully described moler gold and copper. The ropper-gold ores are treated in the varions copper smelters of British ('ohumbia, whilst the galena and silvere orese mainly to the leatsmelter of the (omsolidated Mining \& smelting ("o. at Trail. B.(".

The silver from the Yukon (ontside of the small anount from the fer lode mines now working) is derived from the placer gold bullion, but there are 


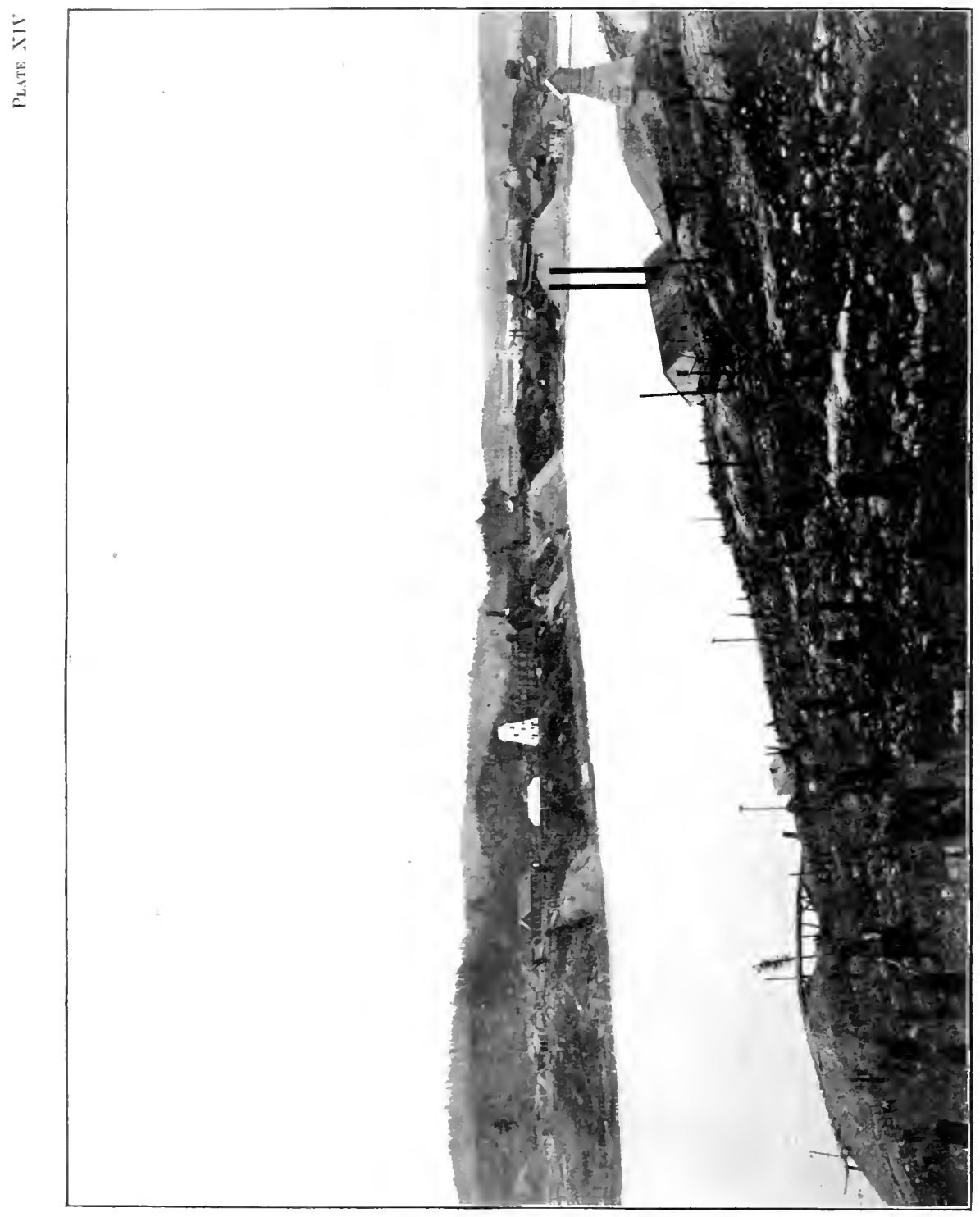

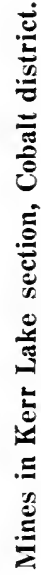




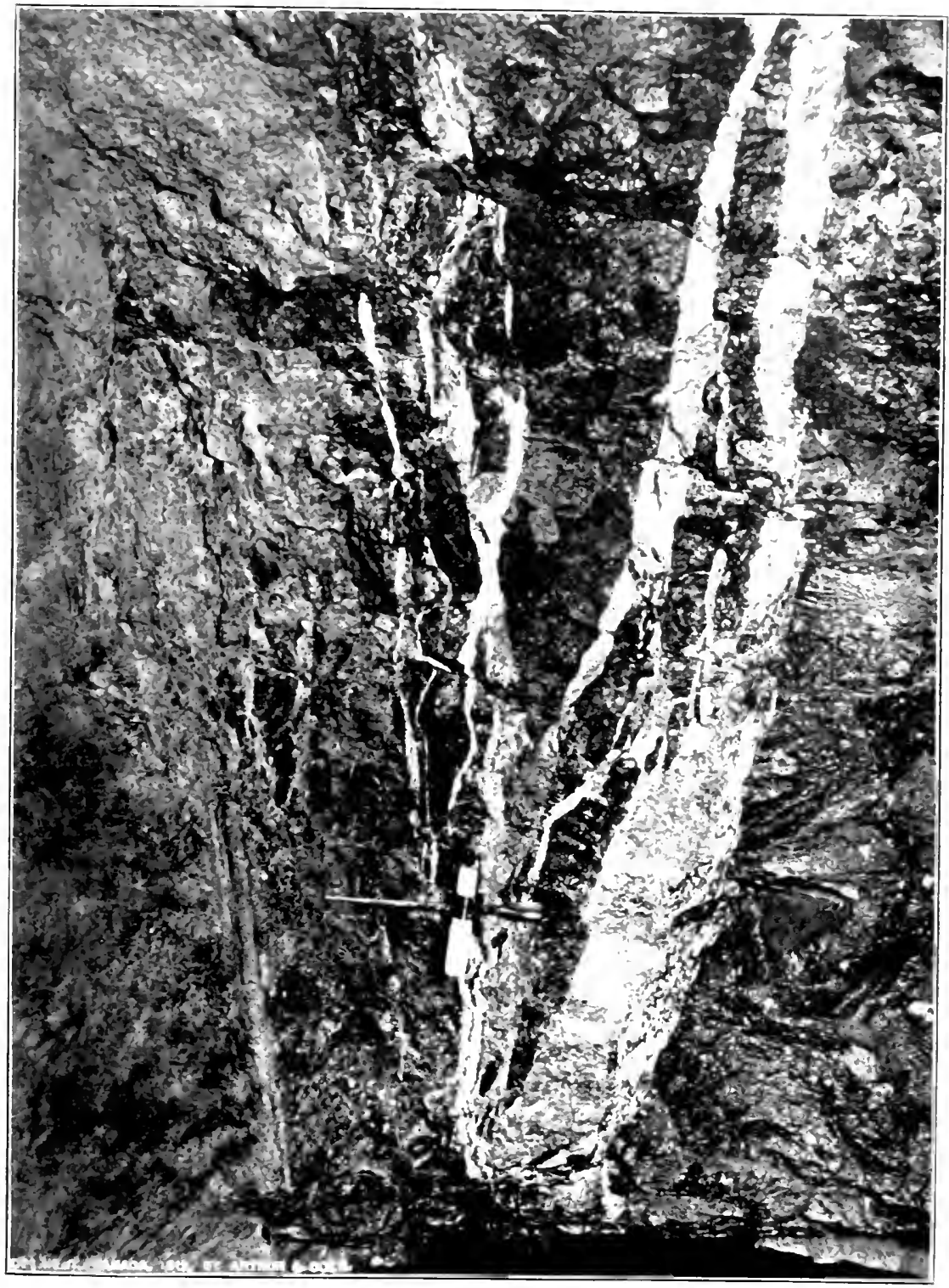

Silver vein. Case? Cobalt mine, Cobalt district. Ont. 
many silver lead properties which will probably become stealy shippers with further derelopment of the country.

Tin.

The oceurrence of tin ore has been reported from sereral localities, the nost important being perhaps the discovery of cassiterite, near New Ross, Luncuburg, Nova Sicotia. Witl respeet to this oceurrence Mr. Faribault states I that "A tin bearing rein was also discovered by Emest Turner, at Mill Road, four miles north of New Ross, and has been prospected under the managenent of A. L. Mce callum. It has heen proved to a depth of 20 feet, and for a length of 250 feet, while the float has been traced half a mile towards the north. The vein is 24 inches wide, mostly made up of quart $z$, merging with granite at the sides, and carries at the middle a streak of rich ore from three to five inches wide. Several assays of the ore made by Mr. MeCallum have given from 10 to 30 per cent tin, and 8 per cent copper, present in the form of cassiterite and chalcopyrite, with association of tungsten-bearing zine minerals."

Tin minerals have also been reported from several localities in British Columbia and from the Yukon district.

There has as yet been no commereial production or recovery of tin from Canarlian sourees.

\section{Tungsten.}

The tungsten bearing mineral scheelite has been found at a number of localities in Canada, but the only place at which it has been worked commercially is at Scheelite Mines, Moose River district, N.S.' Here it occurs in quartz reins cutting the quartzites and slates of the gold bearing series. The quartz veins also earry mispickel and several other minerals but are not gold bearing. A mill has been erected and about 15 tons of eoneentrated ore ( $72 \%$ scheelite) have already been shipped. Scheelite also oceurs in the Malaga gold mining district, Halifax county, while at one locality near South East Margaree in Inverness county, C.B., from 300 to $500 \mathrm{lbs}$. of luübnerite (Fe, Mn) WO, were recovered from a large detached mass of quartz. The mineral has also been noted at New Ross, in Lunenburg county, and at Perry lake, West Waverley, Halifax county, N.S.

In the province of Quebec, scheelite has been found in Beauce county, in a quartz vein traversing Pre-Cambrian rocks, while in Ontario it is found occurring in small nodular masses in parts of the veins around Pearl lake, Poreupine gold mining distriet.

In British ('olumbia its oecurrence has been noted in quartz veins on the Meteor claim, Slocan City mining division, West Kootenay, and also in the Cariboo district at Hardscrabble creek where the scheelite appears to be vory irregularly distributed in the country rock.

In the Yukon territory at Dublin gulch, scheelite is encountered in small water worn nodules of yellowish colour, which are eaught in the sluice boxes at Highet rerek.

The mineral is employed in the steel manufacturing industry making a tungsten steel of high tensile strength.

\footnotetext{
1 Summary Report Geological survey Branch. Department of Mines, 1910.
} 


\section{Zinc.}

The elose association of zine blende with galena and its wide clistribution has made its treatmont one of the economic problems of mining in canada, and its history is interworen with the history of the silver-lead mines.

In the province of Quebec, (alunet island has been the centre of the greater part of the lead-zine mining. Several toms of mixed gatena and blende were olstained on lots 10 and 11. range 15. ('alumet township, in the early nineties, and in 1897 and 1898 the (irand calumet Mining Co. shipped sereral humdred tons of ore to Belgium. In 1903 the Lawn mine shipped $5 \frac{1}{2}$ tons of zinc ore to England. Foms "xploration work was done in later years, and in 1910 the (anada Metal Co. started work, making a trial shipment the next year.

In Ontario the Zenith mine at Rosiport. Thunder Bay, was diseovered in 1881 , and in 1899 the first ()ntario zinc shipment appears to have been made from it. The Balfour mine was also worked for zinc. In 1902 the Richardson mine at Lonw Lake. Frontenae county, began shipping, and, in recent years, has been the zine produce of the provinee. The last couple of years no zine shipments have been made from this property.

The occurrence of zinc blende in British Columbia is frequently mentioned in the earlier reports on the province, but only in 1902 is definite reference made to zinc shipments from the Payne and Bosun mines.

In 1904 we find a number of mines producing zine concentrate, though of this a great deal was apparently never shipped. In the next few years much experimentation was done on processes for zinc treatment, impelled by the high American import duty on zine in ores. 1905 saw the appointment of the Zine Commission by the Dominion Covernment. for the purpose of investigating the zinc resources of British Columbia and their commercial possibilities. The exhaustive report of the Commission was published in 1906. An electric smelting furnace was erected at Nelson in 1908. but did not go into commercial operation. At the present time two mines in the province, the Lueky Jim, and the C.s. are operating for zine alone, while the Monarch, Hewitt, Soble Five. Ruth, Sloean Star, Standard, Yan Roi, and Whitewater are producing hand picked zinc ore or concentrates as a by-product from the milling of galena ores. These eoncentrates as a rule carry values in silver. It is a notable fact that for some rars the Lucky Jim was worked for its silver-lead radues only.

Other properties oecur on Lymn ereek near Vaneonver, at Quatsino on Vancouver island, and at Owen lake, near Hazelton. These as yet, however, have made no shipments.

The majority of the British Columbia galena properties earry enough zinc blende to make its separation and possible recovery a question of much importance.

At present all British Columbian ores are shipped to the smelters in the Enited states. Shipments from Ontario are usually mate to European smelters.

The Mines Braneh of the Department of Mines is now investigating the possibility of producing spelter by an electric smelting process. While considerable progress has been made during the last two years, the commeredal practicability of the results obtained hats yet to be determined. 


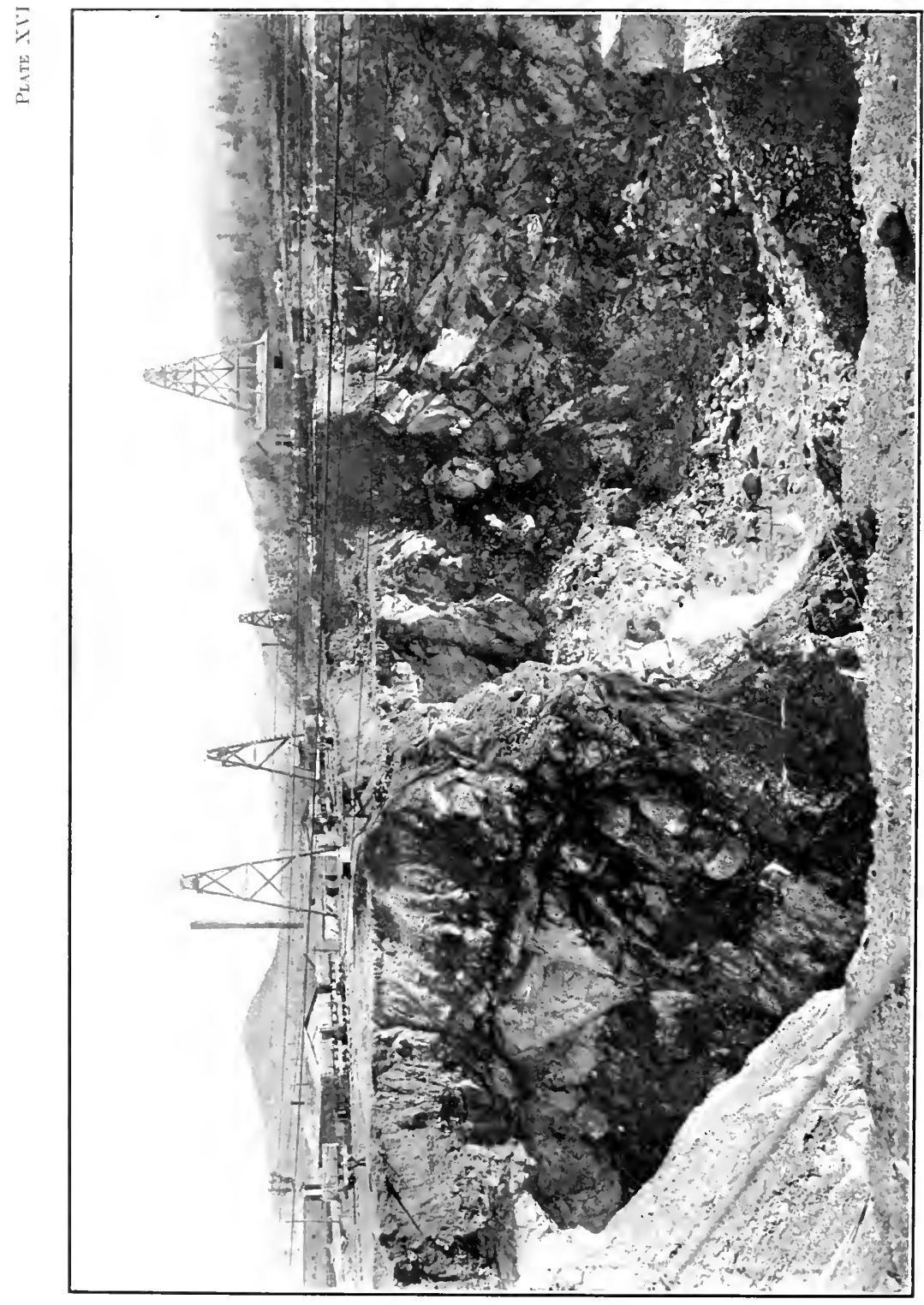

نे 


\section{NON-METALLIC MINERALS.}

\section{Asbestos.}

Supplying as they do a large proportion of the world's consmumption of asbestos, the Canadian deposits of this mineral are of particular interest. While ocerurences of the mineral have been noted in other lowalities and provinees, the principal areas are those fomel in the Eastern Townships, province of Quebec. The present workable deposits are as fat as exploration work has shown, and with the exerption of the Inaville (quarries-confined to the great serpentine range which strikes through the townships of Broughton, Thetford, and Coleraine. Isavine some seattered deposits in the townships of Wolfstown and Ireland out of consideration, the total length of this productive serpentine helt is twenty-three miles, with a wilth varying from 100 feet in the extreme casterly part to 6,000 feet in the Mock lake area; however. the serpentine lodt as a whole in many places far wexeols the width indicated above. Active mining began about 1880 .

The principal deposits oceur at Thetford, Black Lake, 1)anville, and East Broughton: those at Thetford and Black Lake being the most important. The mineral oceurs in a series of narrow and irregular veins, occisionally attaining a width of six inches. though those of the larger size are comparatively rare. Veins with three or four inches of fine fibre were, in the first years of working, quite plentiful; hut as the mines increased in depth these appear to decrease somewhat in size. The voins retionlate through the rock in all elirections. The deposits are worked by open quarrying, the long fibred asbestos of the larger veins being readily separated out, while the smaller material is carcfully cobbed. This separation was at first accomplished entirely by hand, but mechanical treatment has been gradually introduced and perfected until now large mills are in operation in which the rock is broken and erushed in various ways; and the fiberized asbestos taken up from sereens by suction fans, and blown into collecotors or settling chambers.

The ammual production is now over 100,000 tons, valued at upwards of $\$ 3,000,000$ : and inclucles a wide variety of grades from the long fibred crude ashestos, valued at $\$ 300$ a ton, clown to the shortest mill fibre, valued at only $\$ 2$ or $\$ 3$ per ton, and "asbestic" sand nsed for wall plaster, and valued at from $75 \mathrm{c}$. to $\$ 1.50$ per ton.

\section{Chromite.}

Though chromite is found in several parts of ('anada, the only known occurrences of economic interest are situated in the provine of Quebec. In this province, it is found in irregular deposits in the serpentine rocks of the counties of Brome, Meamtie, Richmond, and Wolfe. some of these deposits have been worked, the principal ones being in the township of Coleraine, Mcgantic comnty. The orr in some cases is sufficiently grated for direct shipment, while in others coneentration is neessistry.

During the past few years the output of chromits-or chrome iron ore, ats it is also called-has been very small. This is probably due to the falling off of the market value of the ore.

In its natural state, chromite is used in the mannfacture of special firebrick for metallurgical purposes, on aceount of its high refractory and basice properties. It is also employed in the making of clecetroxles for are lamps, but the main use for this mineral is found in the mamufacture of chrome steel. The chromium contained in it gives to the steel great toughness and hardness, producing a product suitahle for armour plate, metal 
working tools, and many suecial mes. Various chromie salts and colours used in commeree atre deriver from this mineral.

The principal market for chromite is in the Cnited States, but some of that produced in (anada has been manufactured into chrome steel by electric smelting at Buckinghan, Quebec.

It may be permitted to mention here, as an item of interest, that minute diamonds were discovered associated with chromite, which is an accessory constituent of the peridotites in the Tulameen district, British Columbia, and also with some of the chromite in Quebec.

\section{Coal.}

Canada is particularly fortunate in the possession of enormous coal resources. Coal mining was one of the first mining industries to be established, and is still the most important in value of output. Though the development of this industry has been rapid in the past, it seems certain that its future growth will be even more rapid, owing to the settlement and influx of population into those parts of the country-more particularly in the western provinces-in which the principal coal fields exist. Coal is found in five provinces, as well as in the northern territories, the relative importance of each, based on annual output, being as follows: Nora Scotia. British Columbia, Alberta. Saskatchewan. New Brunswick, and Yukon Territory.

Two of the most productive of the Canadian coal fields are situated on the sea-boards, one on the Atlantic coast, and the other on the Pacific coast; a fact which is very important from an Imperial stanclpoint. In each case these coal fields are located on the respective coasts; both have extensive submarine extensions, and are fortunate in possessing fine natural harbours, capable of accomolating ships of any tomage. Another coal field is situated in the proxinity of the metal mining centres of British Columbia, and within fasy rach of the copper and lead smelting centres of hoth the southern part of the provinee, and of the aljoining states to the south. Large tracts of the new western provinees of Alberta and Saskatchewan are underlaid by fosil fuels. All of these coal fields, as well as others of less importance are hriefly described in the following notes, in geographical order, beginning with the eastern provinees, and proceeding westwarl.

To convey some preliminary idea as to the geographical position of the coal fickls in the respective provinces, the central point of each of the principal coal areas is giren in the accompanying list by intersections of latitudes and longiturlas (west of firenwich). These, of course, are only to be taken as a rough guile. and a help to locate the fields. Many of these coal areas are at present well dereloped, and producing stealily. In others, mainly in the watcrn part of ( anada, owing to lack of means of tramsportation or present lack of market, only prospeting work has been done; but their coals constitute valuable reserves which, in many cases, will be drawn upon in the near future, considering the rapid rate at which the west is dereloping, and the establishment of numerous new means of transportation and of communication. 
Geographical Position of Coal Fields.

Finde.

Latitude. Isongitude.

Nova Ścotia:-

Sydney field..................... $460^{\circ} 10^{\prime}$

$60^{\circ} 1()^{\prime}$

Inverness ficld

$46 j^{\circ} 10^{\prime}$

$61^{\circ} 30^{\prime}$

Picton field.

$45^{\circ} 35^{\prime}$

$\left(i 2^{\circ} 33\right)^{\prime}$

Cumberland ficld.

$45^{\circ} 40^{\prime}$

$64^{\circ} \cdot 20^{\prime}$

New Brmswick:-

Grand Lake field.

$466^{\circ} 0.5^{\prime} \quad 166^{\circ} 00^{\prime}$

Manitoba:-

Turtle Mountain field.

$49^{\circ} 00^{\prime} \quad 100^{\circ} 00^{\prime}$

Saskatchewan:-

Esteram or souris field.

$49^{\circ} 05^{\prime} \quad 103^{\circ} 00^{\prime}$

Alberta:-

Belly River field.

$49^{\circ} 40^{\prime}$

$112^{\circ}+0^{\prime}$

Frank-Blairmore field.

$49^{\circ} 33^{\prime}$

$114^{\circ} 2.5^{\prime}$

Caseadle field

$51^{\circ} 12^{\prime}$

$115^{\circ} 30^{\prime}$

Jasper Park field.

$53^{\circ} 12^{\prime}$

$115^{\circ} 00^{\prime}$

Edmonton field

$.53^{\circ} 50^{\prime}$

$113^{\circ} 30^{\prime}$

British Columbia:-

Crowsnest field

$49^{\circ}: 30^{\prime}$

$114^{\circ} 55^{\prime}$

Nicola Valley field.

$50^{\circ} 20^{\prime}$

Telkya Valley field

$54^{\circ} 30^{\prime}$

$120^{\circ} 50^{\prime}$

Groundhog coal field

$5\left(6^{\circ}+5^{\prime}\right.$

$127^{\circ} 10^{\prime}$

Nanaimo field, V.I .

$49^{\circ} 10^{\prime}$

$128^{\circ} 15^{\prime}$

Comox field. V.I.

$50^{\circ} 00^{\prime}$

$123^{\circ} 55^{\prime}$

Suquash field

$50^{\circ} 37^{\prime}$

$125^{\circ} 00^{\prime}$

Graham island. Q.C.I

$5: 3^{\circ} 10^{\prime}$

$127^{\circ} 15^{\circ}$

$132^{\circ} 00^{\prime}$

Yukon Territory:-

Tantalus field..

$62^{\circ} 10^{\prime}$

$136^{\circ} 10^{\prime}$

Yukon River field

$61^{\circ} 30^{\prime}$

$140^{\circ} 00^{\prime}$

In the provinee of Nova seotia there are several large areas of bituminous coal, most of which are being actively workel. Besides supplying local requirements, these coals are shipped to the provinces of Quebec and Ontario, the eastern part of the Cnited States. New Brumswick, Newfommland, Prince Elward Island, and the West Indies.

The coal bearing measures of this province belong to the Carboniferous, and are practieally confined to the one horizon usually designated as the Productive Coal Mieasures.

The Sydney field is situated in the northeast corner of Cape Breton comty, with the magnificent eleep water harbour of sydney as its central 
point ; it also inclutes a small fortion of Victoria county. It is bounded

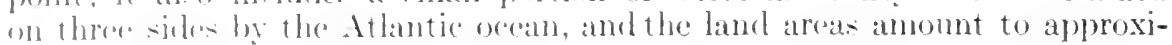
mately 200 sfluare miles, being about 32 miles in length from northwest to sonthoust, and almot 6 miles in width. The extent of thesea areas is monown; hut a creat yart of the lowal fiekl is submarine.

IIthein this area the "xistenere of nine different seams has been reeognizul. ranging in thickness from :3 to 12 feet: these dip at low angles 5 to 12 salard. There ale now working in the district 24 collieries, the output of solne anmonting to as much as 890,000 tons a rear each. The total proHeretion of the field for the gear 1912 was nearly $6,000,000$ tons.

The cont measures of the Inverness field comprise a series of narrow areas on a line extending from Judique to Xargaree, along the western shore of ('ape Breton island. The exposed measures skirt the shores of the Gulf of st. liawrence for a distanee of about 60 miles and extend inland a few miles, hint lip under the soa to unknown distances. Some of the areas have been workal since 1866 , but no extensiva operations were undertaken until railwaly comnexion was made with the Intereolonial in 1900.

The Pictou field, situated in the centre of Pictou county, in the easternmost field on the mainland of Nova seotia. Its area is comparatively small; the coal measures which constitute it extend about 12 miles in an east and west direction. and hare a maximum wilth of abont 3 miles: its total area is approximately 2.5 square miles. The town of New Glasgow lies on it: northern bountary abont half-way between the eastem and western (xtremitis. The field. therefore, lies about 9 miles from the shore of Northumberland strait. Although small in extent, its geology is complicated, and the eorrelation of strata is rendered difficult owing to the oceurrence of numerons faults which surround it, and cross it in diverse directions. Active mining begin at about the same time as in the cape Breton field. There are now five collieries, with a total annual output of ahout 785.000 tons.

In ('umberland county there are two areas of Produetive Coal Measures, and atctive operations are carried on in both districts. ()ne of these, the springhill eoal field, is situated approximately in the middle of the county and about 20 miles from the sea-coast; the other, the Joggins or Northern Area, is hounded on the west by (hignecto bay. The coal seams range from 2.5 to 13 fort in thickness. In both fields are well developed collieries worked he sopes driven into the seams. The total production of the cumberland field for the rear 1912 was about 6.54 .525 tons.

In the province of Xew Brunswick the coal seams which are being worked are reforable to the Nillstone Grit formation. whith in Nora Scotia mulerlies the Produetive Measures. Only two areas have been dereloped into producing and fidds. The first of these, which is also the largest, is the Giturl Lakn area, situated in Queens eomnty. In this eoal field the measures are very nourly horizontal, and for this reason. while they do not comprise a ereat thichnes of strata, they oceupy a considerable area. Two seams of coal oreme in this fold, separaterl in places by partings of rarious thieknesses. The top of ono is alont 20" thick. while the lower bench is 10". Sometimes they conn together and make a workable seam of $30^{\prime \prime}$. The coal occurs quite nour the surface, and the drepest shafts in the distriet do not exceed 40) feet. This field (smbraces an area of about 112 square miles. The coal industry in the district can hardly be said to have passed the preliminary - tager, although it has been established for many years. Small mines are comparatively numerous, each being worked individually and many of them intermittently. The scond field in which mining is being carried on on a small scale is in lient county, in the vieinity of Beersille. A small seam, 


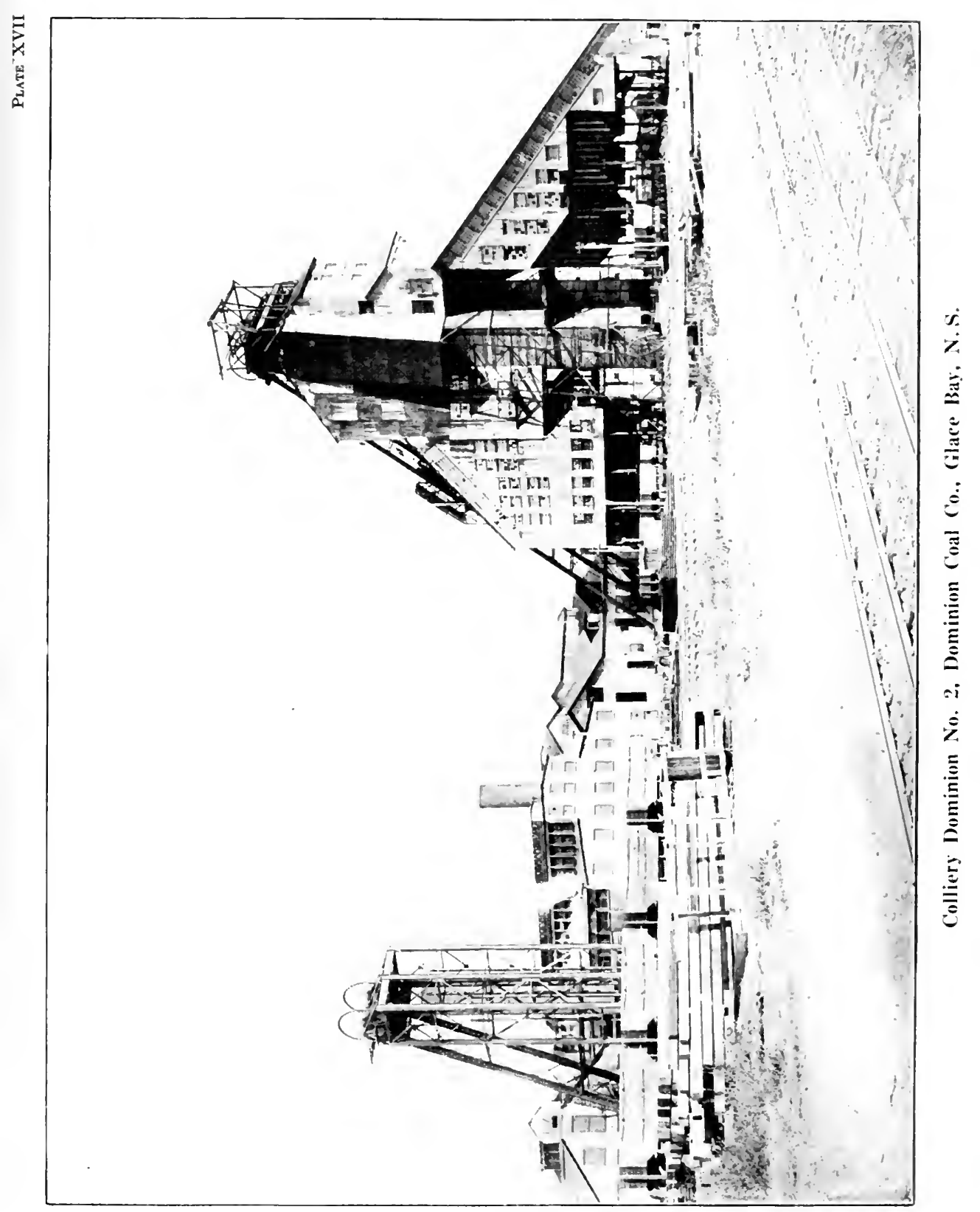


meker 20" in thickness, is workerl on the banks of coal branch, a tributary of the Richibureto river. The allutal ontput of the province is now from

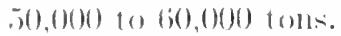

In wostru ('amarla, mulike the mastern part of the Dominion, where the roal sams ane fomml in horizons of carboniferous ane. the mincral fuels alre asocolated with rocks of ('rotaceons and Tertiary ages. This remark alpplies to the coal fiekls of the plains and the interior of British Columbia, as well an to the coal-hearing areas of Vaneouver and Graham islands.

The Turte Momentain coal field in southern Manitoba is approximately hisereted by the longitude meridian $100^{\circ} 15^{\prime}$ west, and its length in Canada is alout to miles east and west along the 49th parallel of latitude, which practically hisects it. The southern half lies in the State of North Dakota. The hrealth in (anarla is about 20 miles north and south.

According to Mr. D. B. Dowling, "the coal horizon does not appear to consist of a series of seams in continuous sheets, but rather of deposits which are limited in extent, though repeated over large areas, and often superposed without the intervention of mueh clay and sand. The material from which the coal was derived scems in many instances to have been made up of a large pereentage of woody matter, but a great part is probably composed of much smaller plant remains, similar in character to much of that in our present swamps and peat hogs, though of different species, such as would be found in a wamer climate." In quality, this fuel is lignite, rather high in moisture. It disintegrates easily on drving, and will not stand long transportation in its natural state, but eould be of great importance for local usage. Seams have been worked at various points in a small way, but no regular mining is done.

In the province of Saskatchewan, the Souris coal field forms the northern extension of the North Dakota lignite bearing region. The brown coal beds are in this case contained in horizons constituting the base of the Tertiary. The seams are numerows, but owing to the character of the country and to the thick covering of superfieial deposits, it is rery difficult to study the coal formation in this district. The area eovered by the coal-bearing horizons in this part of the province of Saskatchewan exceeds 4,000 square miles; it extrods some 1.50 miles along the International Boundary, from longitude $102^{\circ}$ westward, and has an approximate arerage width of 25 miles north and south. (Of this immense tract, only a very small portion is being worked or has been sturlied in detail; very little is known of its possibilities berond the small area in which are situated the mines near Esteran on the St. Paul line of the Canadian Pacific railway.

The lignite is rather low in fixed earbon, and high in moisture. These conditions make it difficult to transport or to store without great loss, and are also procluetive of great waste in the course of mining. On a eomparatirely short exposire to the air, the contained water is lost, and this eauses at disintegration, and in time a reduetion to powder.

From the commereial standpoint, the lower seam is the most important, and as it attains a thickness of $S$ feet, this would yield some 11,000 tons an acere, we narly $10,000,000$ tons to the square mile.

(ias producer trials on these coals as well as on other lignites from Alberta show them to be cxeellent fuels for use in gas produeers. The annual output of the somris field is about 200,000 tons, which finds a market locally and in the Provinos of Manitoba.

Allerta posiesos ly far the most extensive coal areas of any province in ('anarla in fart, the greater part of the southeastern part of the province 
appears to be molerlaid with coal- Dowling has estimated the known and mineable coal areals at not less than 30,000 serluare miles. These coal arreas oceur in three divisions of the cretaceous. The lowest is exposed in long narrow helts in the outer ranges of the Roxky momtains and the foot-hills. These ancas besides providing the best coal, are also important in that they

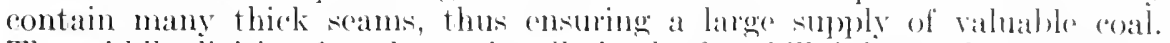
The midelle division fomel oecasionally in the foot-hills is lietter known as the Lethbridge coal-bearing rocks which are exposed orer a large area in wastron Alberta, and furnishes a coal which grades from bituminous to sub-bitmminous and lignite. The higher coal-bearing beds are woll exposed in contral Alberta, and from the well-known coal seams on the North saskatchewan have received the name "Edmonton loeds." These, in the western erlge of the area, contain scans approaching bituminous, but in the eastern part the coal is sub-lituminous.

\section{Coals of the Edionton Formation or l'pper ('retaceous}

The area oecupied by these rocks is a large triangle, with its western edge parallel to the Rocky momtains, and the astern edge nearly north and south adjacent to Lethbridge coal areas. It forms a trough in the centre of which is the remnant of the sandstone formation of the carly Tertiary. The western portion produces coal that may in many cases be classed as a soft hituminous, while the castern portion eontains sub-bituminous coals only.

In the immediate vicinity of Edmonton there is a rery persistent bed of lignite, lying practically horizontal a few fect alyove the level of the river, and this is extensively worked. This seam gives from 5 to 6 fret of good, clean, lignite, whieh is mainly used for domestic purposes.

The Belly Rirer eat formation occupies the middle of the crotaceous in the geological scale and includes the Lethbridge-Nedicine Hat area, the Battle River area, as well as areas in the foot-hills and on the Peace river near Dunvegan. The principal collieries are being operated between Taber and Lethbridge and at Lumelloreck. The quality of the coal varies from sub-bituminous to lignite, the higher class coal being found on the western margin.

On the eastem slopes of the Rocky mountains there occurs a zone of erumpled roeks which have been subjected to very great dynamic disturbances incheling folding and faulting. The coal hearing areas of this zone eonsist of elongated troughs of lower and midule cretaceons rocks formed by the folding of the strata. The quality of the coals of these measures varies from bituminous coking and non-coking coals to anthracite containing s.) per cent or more of fixed earhon; the amount of volatile matter depending largely on the degree of dynamice disturbanee molergone by the beds.

The whole belt of the foot-hills and adjoining disturbed country to the east of it might be considered as an almost continuous zone strung with discomneeted coal-bearing troughs of rocks of the Kootanie series; but from the commeredal standpoint it may be divided into separate, and more or less well-defined eoal ficlds, of which the Blairmore, linak, ('ascades, and Jasper Park areas are being worked. The Blaimore-linank fock is situated in the southern part of the provinee and is served by the Crows Nest branch of the Canadian Pacifie railway. The coal, as a rule, is of good quality, although generally high in ash; when sufficiently pure or after washing, it vields a good coke. There are 12 large collieries in active operation, besides a mumber of less important openings. In the Cascade Mountain region on the main line of the Canadian Pacific railway, of which Banff is a woll known point, 


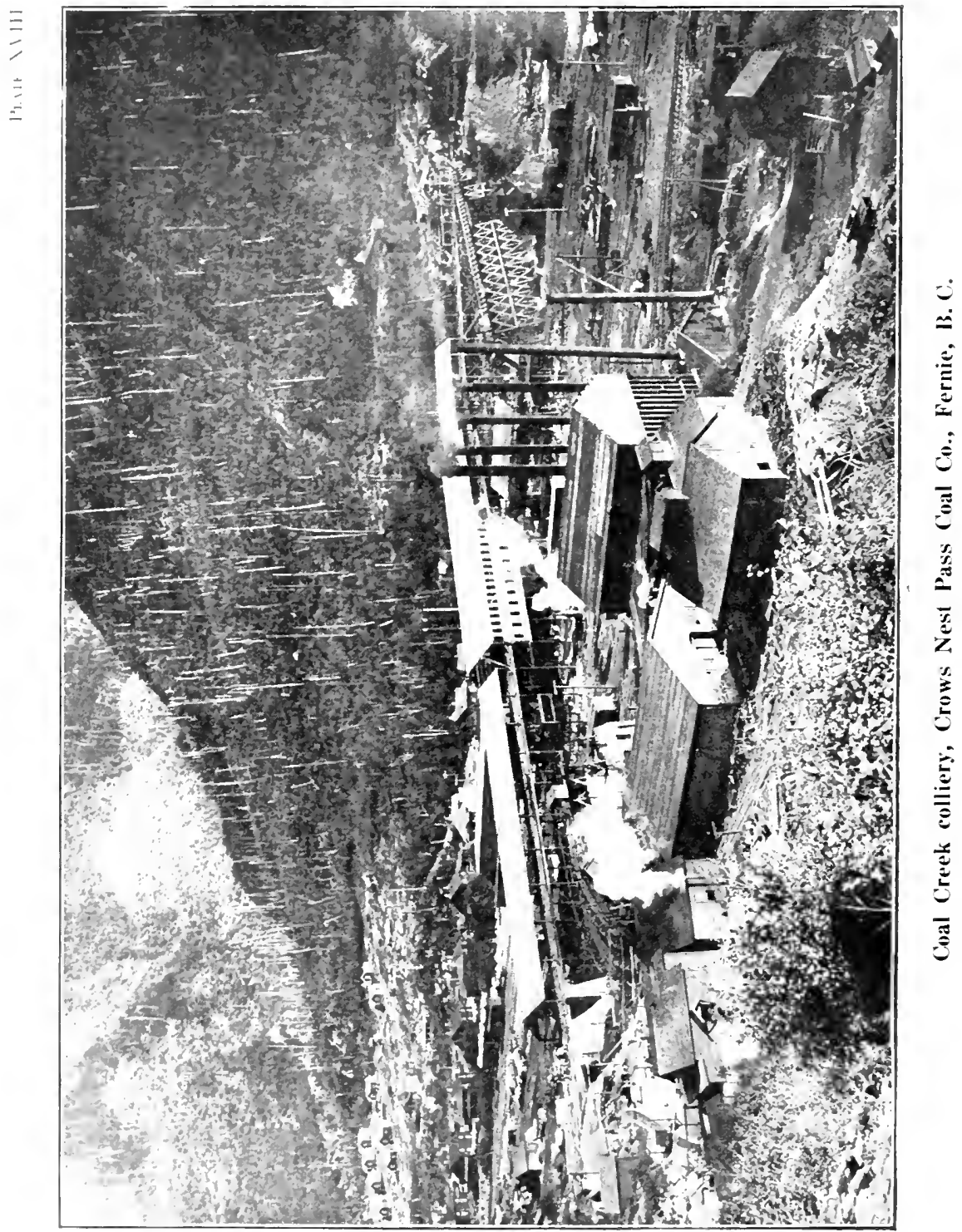


two coal areas are now heing worked, the respertion contles of which are Canmore and Bankhead. The coal produeed at Bankhead mine is rery high in fixed cartwon, and is pratetically an anthracite. It is rem friahle, and as prepared for the domestite market, it repuires a gereat deat of sizing and

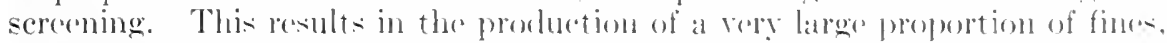
or anthracite dust, which is briguetted and makes a vely sitisfactory fiuct. The (ascate basin also extends south of the main line of the ('anadian Pateific railway, below the (ammore area, and good seams of conl have been discorered in the distriet of the kimansisis river. Farther northward, important areas have been discovered in the Bighorn basin between the Saskatchewan and Brazeau rivers, the Nekanasin area extending from the Brazean river to the head waters of XeLeod river, and the da-per Park areas. There are important derelopments in progeres on the line of the cirand Trunk Pacifie railway, or tributary to it, and one or two collieries are alleady in operation. Altogether, including large and small, there are nearly 20) collieries now in operation in the provinese.

The eoal production of the provinee of Alloerta has increased from less than 100.000 tons in 1886 to nearly $4,000.000$ tons in 1912. and it will probahly not be many rears before the output exeech that of any other provinere.

In British Colmmbia there are three main distriets in which eoal mining operations are heing actively pursued. These are the ( rowsnest Passegion in the easterm part of the provinee: the Nieola Valley district. in the central part; and the east coast of Vincomver island. Besides these other coal basins are known and more or less prospected. but at present are too remote from means of commmication to be of immediate economic vahe. although they constitute a reserve of fosil fuels with great posibslities.

The Crownest Pass coal field is situated immediatedy west of the summit of the Rocky momntains, in crowsnest pass. It is all included within the province of British ('olumbia. excepting a small portion in the immediate vieinity of the pass, which erones the watershed into the provine of Albertat. The Crows Nest branch of the (anadian Padife railway croses the morthern part of the coal field. and skipts its western edge for at distaner of 2.5 miles. The rocks of the eoal field are of cretaceous age. Mr. Jas. Me Eroy has made an approximate estimate of the total arailable coal in this field. By taking the area covered by the coal measures as being $2: 30$ suluare mikn and assuming a workable thickness of coal seams of 100 feet, which does not appear to be excessive. he arrives at a total fuantity of 22.59.5,200,000 tons. The opening of the coal mines in this field marked an epoch in the derelopment of British Columbia. Before this time the smelting industries of the Kootenays, and of Washington in the Enited states. had to depend, in a great measure, on coke from the coast eoal mines, the transportation of which. added to a comparatively high initial cost. rendered this fuel reery expensive: in fact, the cost of fuel to the smolters has sinee then been roduced to ahout one-half. Three large companies are now operating, and the output in 1912 was $1,413.583$ toms or about 50 per eent of the total output of the proviner.

Immediately to the north of the Crowsnest Pars luasin of coal measures, but separated from it hy a belt of the molerlying limestones. there is another trough of eoal-bearing ( some 50 miles, crosing the summit of the main range. into Albertas at the Kamanaskis pass. The difficulties of atecess, as compared with the other coal areas lying elose to the railway. have militated against the immediate active development of these areas: but a railway line, eonnecting with the Canadian Pacific railway at Miched, has been located. and it is probable that before long this coal fiedel will he exploited. "That large quantities of 
coal exist in these measures was definitely proved in 1901, by a party of the (ienlogical surver, when in a section of 3,386 foet, some 12 seams were observed, varying in thickness from $8^{\prime \prime}$ to 35 feet.

The southern interior of the province contains a number of coal fields of growing importance. Near Princeton, one colliery has been already opened and has made small shipments of lignitic coal; but the area of this ficld is great-probably nearly 50 scpure miles-so that there appears a ertainty that sereral other mines will eventually be opened up. In the Truameen valley, near Granite creek, the Columbia Coal \& Coke Co. is ancleavouring to open up a colliery; there are some very promising outerops, (tr.. high up) on Giranite ereek and Collins gulch, but the long tumnel which the ('ompany is driving to eut the coal at depth has not, as yet, been successful in cutting workable coal. Mr. Camsell, of the Ciecological Survey, estimates this basin to have an area of about five square miles. The Nicola Valley coal ficld is situated to the south of Nicola lake in the Kamloops district of British Columbia. Although not as extensive as the Crowsnest fiekl, or the Vancouver Island field, it is yet of great economic importance. It stands mid-way between them, hence the coal of the Nicola valley is manifestly destined to find a market in a considerable part of central British Columbia.

In the northern interior there is another prospective field which attracts great interest at present, owing to its proximity to the line of the Grand Trumk Pacific railway, which is being constructed through this district. This is the Telkwa Valley field, in the northern part of British Columbia. Some of these areas are of considerable extent, and several have been proved to contain coal of good quality and in beds of workable thickness. The character of the coal varies from a bituminous to a semi-anthracite.

About 140 miles by trail north from Hazelton near the headwaters of the west fork of the Skeena river, is another coal field of great promise, known as the Grounclhog coal field. This coal is anthracite or semi-anthracite in character. From present indications and developments it would serem though this coal field would prove to be one of the most important developments that the province has seen for many years. The field is, as vet, only slightly dereloped, and, if but a fraction of its present promise is fulfilled, it is boind to have a wonderfully stimulative effect upon the future of the province. The centre of this field lies approximately in $56^{\circ} 45^{\prime}$ north latitude, $128^{\circ} 15^{\prime}$ west longitude. It was first discovered in 1903 , though its full extent was not at that time recognized. More recent explorations have shown the field to extend in a northwesterly direction about 75 miles, and to have a width in places of about 30 miles. The rocks in which the coal occurs have been classed as of Cretaceous age. As illustrating the comparative importance of such an area as this, it may be stated that this area alone probably contains as much coal-possibly ten times as muchas is found in all the present known coal areas in the province of Nova Scotia.

Vancouver island has been the seat of a coal mining industry since 1836 , which in recent years has not only supplied a local demand but has been largely exported, to the state of California. The Vancouver Island fields, now being exploited are situated on the east coast of the island. These coal measures may be naturally divieled into two distinet fields, separated by a gap of 12 miles of crystalline roeks in the district of Namoose. The northern area is thre comox ficld, and the southern one the Nanaimo field. Another field, until reoently quite undereloped, exists in the vieinity of Suquash, about 125 miles to the north. Seven collieries are now in operation in the elistrict, and the production in 1912 was $1,571,682$ tons. 
The eoals of the valrious seams, although each has its own individual characteristics, are, as a whole, much alike, and furnish a bitmuinous ead of fair grade, the amount of fixed calbon in the hest guality ranging from 50 to 60 pere cent. and the pereentage of ash frons 5 to 10 pere cent. The most striking feature of the seams is their great variahility in thiekness and wharaeter. The thickness varies from a few inches to orer 30 foed, sometinnes within a lateral distanere of less than 100 foet.

Coal is also found in the Queen (harlotte islands, the most important coal-bearing group known in this group of islands boing that found in at development of cretaceous rocks on Gralam iskand, the most northerly island of the group. In this field, coal onterops hare been located in sereral places between the skidegate chamnel and rakoun lake in the interior of the island.

In the Peace River valley extensive coal fields are loeated and partly prospected, but these are as yet far from transportation.

Near Bear lake and river, tributaries of the Fraser river near its most northerly heat, and near the located line of the (irand Trunk Pateifie railway. a coal area is being developed which, aceording to recent reports, has considerable promise and, heing near the railway, assumes importance.

In the Yukon territory, coal and lignite oecur quite extensively. Three of the most important loealities containing these fosil fuels are: (1) The Whitehorse coal area: (2) the Tantalus coal area: and (3) the Rock Creek coal area. In the two most southerly localities first mentioned. the coal measures occur mainly in the Tantalus conglomerates, hut are also found, to some extent, in the upper portions of the underlying Laberge series. These rocks are all Jura-Cretaceous in age. The coals in the Rock Creek area, so far as is known, are all lignites, and oceur in beds of Tertiary age. Probably the most important of these coal-bearing distriets is the Tantalus area. which crosses Lewes river midway between Whitehorse and Dawson, and in which are situated the Tantalus mine, the Tantalus Butte property, and the Five Fingers mine. Coal is being mined in the Tantalus field and in the Rock Creek area at Coal creek below Dawson.

The total production of coal in Canada in 1912 was 14.495.302 tons. Canada is also a very large importer of eoal, the imports in 1912 having amounted to $14,595,810$ tons, and exports 2,127,133 tons. The contral provinees of Ontario and Quebee being the chief eentres of population, are large eonsumers of coal, and owing to their extreme distance from domestic source of supply find it more economical to import coal from the nearer fields of the Enited states.

\section{Corundum.}

In spite of the large increase, in late years, in the manufacture and ronsumption of artificial abrasives, sueh as carborundum, alumelum, cte., natural corundum is still preferred for certain purposes, and the Canadian deposits of this mineral vicld practically the entire supply. ln 1912 the production amounted to 1.960 tons, valued at 5239.091 .

The corundum mines are situated in the eastern portion of the provinee of Ontario, in the townships of Carlow and Raglan, and mining operations have been in progress since 1900. At present, mining is heing eonducted solely by one corporation-the Manufacturers ('orundum ('ompany- who have acquired the mines and mills formerly operated he the Ontario Cormdum Company, in Carlow, and the Canarla Corundum Company, in Ratalan. 
'The wommlum orents in the form of ervats of various sizes, disseminated in syente, aml is wom ly pluarying the matrix, hand-sorting the broken mek, and orushing the righer material, with subseguent wet concentration. The arerage rormulum rontent of the lock trated does not much exceed (i per cent, and, as fom $1 \frac{1}{2}$ to 2 per cent are lost in concentrating, the recovery repuresents aloust 4 pere cont of the crute material.

(onumbun-leaming rocks were first reognized in this area in 1897 , and the mincral is fommel sparingly, hut waldy distributed in the rocks of this listrict.

\section{Feldspar.}

This mineral is amployed at the present time almost entirely in the pottery industry (where, in a fincly ground form, it is mixed with the elay to ald as a flux), or in the enameling of cooking and similar utensils. Attompts are being malle, also, to utilize the mineral as a source of potash; of which it continis as high as 14 per cent.

Feldspar has been mined in Canada since the year 1890, and the present arelage ammul production is 12,000 tons. Practically the whole of the ontput is exported to the Cnited States, where it is consumed in the New Jerser and (Ohin potteries. Almost the entire production of Canadian feld-par is lerivel from the province of Ontario-the principal mines being located in the comnty of Frontenac, about twenty miles north of the town of Kingston on the Sit. Lawrence river. A few small deposits, also, have leen worked in the Parry Sound district, in the vicinity of the Muskoka likin. Formerly felchpar was mined to some extent, also, in the province of (uebec - the deposits heing located in Ottawa county. No development of these properties has taken place during recent years-the distance from

the United states factories rendering mining unprofitable. One mine in this region yiclds a remarkably pure white feldspar, which is in demand for the manufacture of artificial teeth.

Trins or dykes of pegmatite (a rock having feldspar as its main contiturent) are of common oceurrence throughout large areas in both Ontario and (buelser, and have in some instances been mined for the mica which they often carry. These deposits vary in width from mere stringers of a few inches to massive bodios of wer a hundred feet. Such deposits, while, at the present time, often too renutely situated, or containing too many impurities in the way of aceessory minerals to allow of the feldspar being employed for pottrey puposes without comsiderable expensive cleaning, constitute large leserves of the mineral, which may ultimately prove of value as a source of potash or for other purposes.

\section{Fluorspar.}

1 Thesit of flumspar his been worked in the county of Hastings, provine of (Intario, where a larere vein of this mineral oceurs. About 250 tons hate heen mined to dite, the output being consumed in steel furnaces and other smelting works. The vein averages two to three feet in width and has

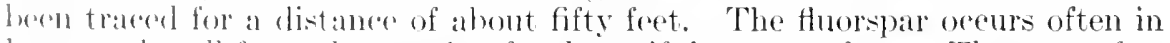
linge and well-formed arytals of a beatiful green colour. These are frequently eorted with orystallized harytes, and are much prized as museum yeceimens.

Mincraldegially the oremrence of fluorite has been noted at several points in New Brinswick, (Queloce, Ontario and British Columbia, and one 
oceurrence near Nelson, B.('., was investigated as a powsible sonrce of the mineral.

Further uses of fluorspar are: as a substitute for eryolite in the manufacture of aluminium; as a bond in the manufacture of emery wherets; in earbon electrodes-to increase the lighting efficieney and to deacaso the current; as a desulphurizing agent in the open-hearth roating of ores. It

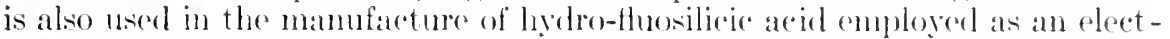
rolyte in the electrolytice refining of leat.

\section{Graphite.}

Graphite is foumet in many parts of the provinces of ( nntario and Quetee, and also, to a lesser extent, in several of the other provinees.

On Cape Breton istand and in the eounties of Cings)orongh, Colchester, and Kungs, Nova seotia, araphite has been observed, but no deposits of commereial importance lave yet been recorted.

In New Brunswick - though in late years no graphite has been minedthere are several deposits that have been worked on a small seale, at intervals, since 1853. These are situated in St. John eounty near the eity of St. John. It also oceurs in the counties of charlotte, Kings, and IVestmorland.

In Qucbee, only one company is operating at present, though several others have been mining and milling graphite until reeently, and will probably resume work later. The principal eleposits of eraphite are situatere in the townships of Buekingham and Lochalere, (Ottawa comnty, near the town of Buekingham, and in the township of Cirenville, Argenteril county.

In Ontario four companies are engaged in mining and milling sraphite. The operating mines are situated in the following townsips: Bromgham, Renfrew county; Cardiff and Mommouth, Haliburton county; Montragle, Hastings county; and North Elmsley, Lanark county. Other important deposits of graphite are found in the counties of Haliburton, Hastings, Ardington, Frontenae, Leerls, ancl Lanark. Some of these deposits have ahready been worked to some extent.

Both in Quebee and Ontario the majority of deposits of graphite oecur in the rocks of the Hastings-Grenville series and are of three classes:-

(1) Veins of columnar or foliated graphite.

(2) Lenticular masses of flake or amorphous graphite.

(3) Flakes of graphite disseminated through the eountry rock (crystalline limestone, gneiss, and quartzite.)

Practically all of the deposits in which mining has been done belong to the third elass. The graphite is extracted from the rock and prepared for the market by an claborate system of milling.

In British columbia graphite is reported to have heen found at Rivers inlet and Alkow harbour.

Explorers have reported the presenee of this mineral in sereral localities in the far northern parts of Camala.

Graphite is used in manufateturing pencils. crucibles for motallurgieal purposes, eleetrieal apparatus, store polish, lubrionts, heat and weather resisting paints, foundry facings. ot ce, ote.

Artificial graphite is made in ('anada near Niagara Falls by means of an electrie process. 


\section{Grindstones.}

The Millstone Cirit, a carboniferous formation which is widely distributed in Noxa seotia and New Brunswick, is quarried and manufactured into grindstones of excellent grades. These range in size from very small stones to those used for the grinding of wood pulp, which weigh about $2 \frac{1}{2}$ tons each.

The producing quarries and works are situated at Lower cove and Quary island in Pietou county, Nova Scotia; and in New Brunswick at IVoolpoint, Rockport, and Beaumont in Westmorland county, Stonehaven and clifton in Gloucester county, and Quarryille in Northumberland county.

Stone, reported to be suitable for grindstones, is found in a number of localities in other provinces, but has not been quarried to any extent.

\section{Gypsum.}

Many large deposits of gypsum oceur distributed throughout Canada; the most extensively mined arcas being those in the Maritime Provinces of Nova scotia and New Brunswick where the mineral is found associated with rocks of the lower Carboniferous series. Many of these deposits are exposed in cliffs which vary from 50 feet to 200 feet in height.

In Nora Scotia, the principal districts in which grpsum is found are in Hants county, near Windsor; in Cumberland county near Amherst; in Victoria county near McKinnon Harbour; Baddeck, and St. Anne; and in Inverness county near (heticamp. Crosum also oceurs in large quantities along the coast of Cape Breton island, in the interior, and along the shores of the Bras d'Or lakes.

In Now Brunswick the principal deposits oecur in Albert county in the district around the town of Hilkborough; near Petitcodiac in Westmorland county: and in the northern part of the province on the Tobique river at Plaster Rock, in Victoria county.

A comparatively small proportion only of this mineral mined in these two provinces is manufactured in Canada into plaster of Paris, wall-plaster, fertilizer, ete., the greater part being shipped crude to the United States.

Gypsum occurs in several of the islands of the Magdalen group, province of Queber, where it is also associated with the limestones of the lower Carboniforous series.

In Ontario cleposits are found in Haldimand county along the banks of the Cirand river, the oceurrence being in the Onondaga formation in beds arcraging about 4 and 11 feet in thickness. A small ammal output, which is mostly calcined, has been maintained for many years. Occurrences have also been noted in the northern part of the province along the banks of the Morse river in the Hudion Bay basin, about 30 or 40 miles south of Moose Factory.

In Manitoba largo workable deposits of gypsum oceur in an area about 8 miles square situated about 170 miles north of the city of Winnipeg. These deposits are being operated and the rock transported to Winnipeg, where it is calcincel. (iypsum has also been encountered in drilling operations in the southere part of the province.

In the prairie provinees gypsum is found north of the eity of Edmonton at soreral localities in the district tributary to the Mackenzie river. 


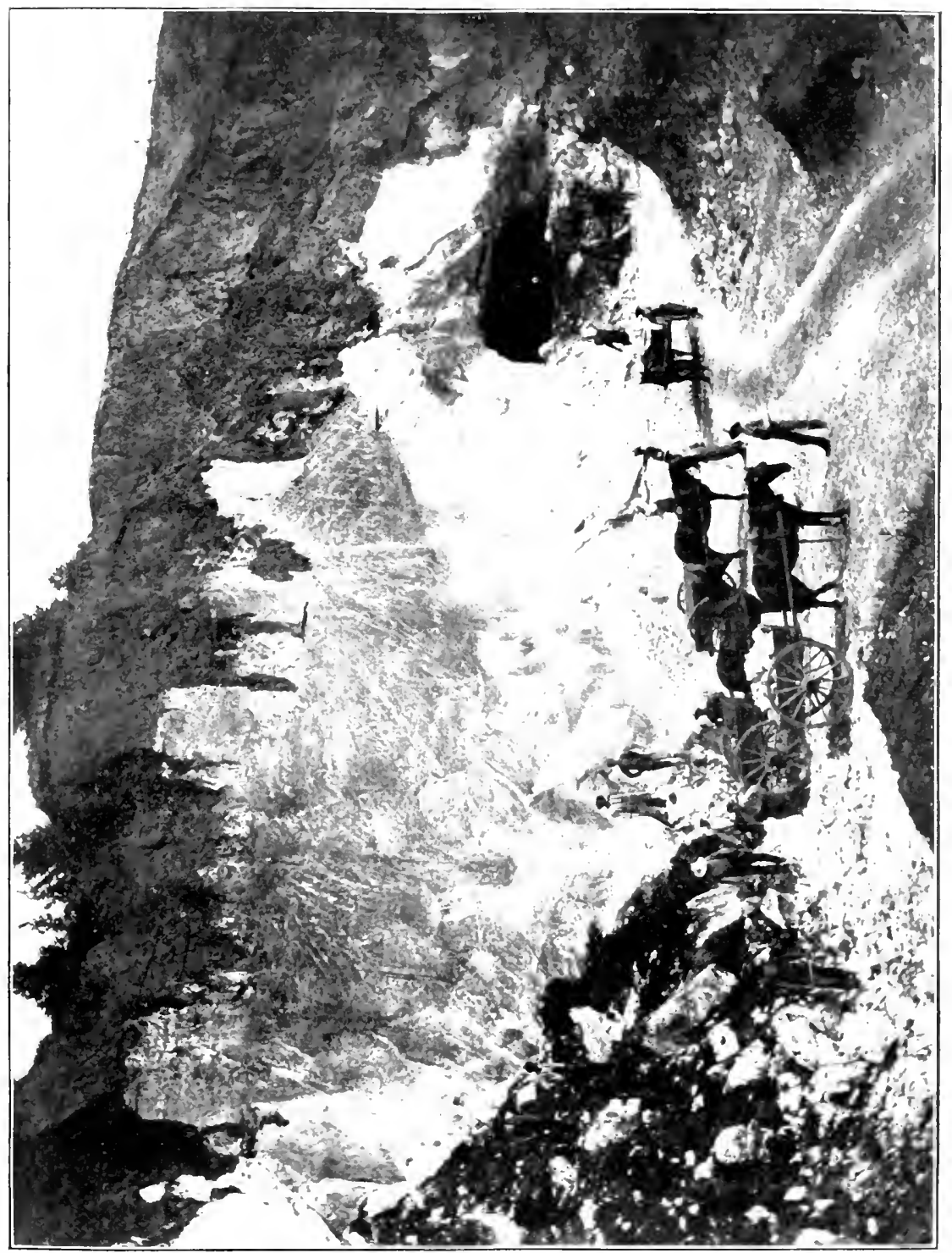

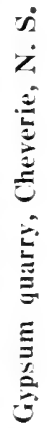


It is also found in British Columbia at the following places: Salmon river in the southern part of the Kamloops Mining Division; Spatsum on the main line of the C.P.R. aloout 189 miles to the northeast of Vancouver; on the banks of the 'Thompson river about 20 miles to the north of the town of Kanloops; at Merritt in the Nicola valley, and in the Tulameen district on Granite areek, about 10 miles up the Tulameen river from the town of Princeton.

The quality of the gypsim found in Canada, more expecially the white rock found in Nova seotia, New Brunswick, and Ontario, is of an exceptionally high grade. The mineral is used in many of the fine arts, and is extensively employed in the manufacture of structural materials, such as plaster of l'aris, hardwall plasters, cement, ete. It is also used in the crude state as at fertilizer. The output of crucle gypsum for the year 1912 was 576,498 short tons, valued at $\$ 1,320,883$.

\section{Magnesite.}

Magnesite is being quarried in the township of Grenville, Argenteuil county, Quebec, about 10 miles north of the town of Calumet. It occurs in the crystalline dolomitic limestone of the Hastings-Cirenville series, at several points in this township, but the extent of the deposits is not known as much of the comntry is covered with soil and vegetation.

This mineral also occurs in deposits of considerable size in Brome county, Quebee; in several loealities near Atlin, British Columbia, and in Yukon territory. These deposits have not been worked on account of contained impurities in some cases, and in others on account of lack of a close market.

Magnesite, after being calcined, is used in the making of sulphite pulp, fireproof flooring, firebrick for basic steel and copper furnaces, ete, and in the preparation of chemical products of magnesia.

During calcination it gives off carbon dioxide equal to about half its weight. Where the calcining is done in retorts, the carbon dioxide may be saved and stored in iron cylinders, under pressure, for use in aerating soda water, etc.

\section{Manganese.}

Ores of manganese found in Canada comprise pyrolusite, manganite, psilomelane and wad or bog manganese, and these are found principally in the eastern provinees of Nova Scotia and New Brunswick.

Mining operations have been conducted at Loch Lomond, Cape Breton, Temnyeape, Walton and Cheveric in Hants county, Last Onslow and Londonderry in Colchester county in Nora Scotia. In New Brunswick there are numerous oceurrences and production has been obtained from Markhamville and Jordan Mountain in Kings county; Ouaceo head, St. Johns county; Shepody mountain and Dawson settlement, Albert county.

Considerable deposits have been found on the Magdalen islands in Quebee, and ocentreness have beren noted at valrious points in Ontario and on the mast coast of IIudion hay.

The only active operations being undertaken at present are those at Now Rosin in IIants eounty, Noval Seotia, where the Nora Sicotia Manganese ('o. alre deroloping a property from which several hundred tons have already been shipped. 


\section{Mica.}

Canada is one of the three principal mica-producing countries of the world, the others being India and the Enited states. The average value of the mica prodiced amnually in Canada during the last ten years has been about $\$ 185,000$.

With the exception perhaps of Ceylon, Canarla is the only country, as far as is ret known, in which the variety phlogopite-or "amber nuical," ats" it is termed in the trade--is known to ocene in eomomic quantities. The miea of commeres is of two kinds-muserovite, or "white mica," and phlogepite or "imber mica." The former is obtained from both India and the Enited states, while the latter is secmed almost wholly from Camada. of the two varieties, phlogopit" "ommands rather the higher price, being softer and more flexible and altogether more suitable for use as an insulator - this being the principal use to which miea is put at the present day.

The amber mica teposits of Canada are comprised within an area of approximately 1200 square miles in the province of Quebee, and 900 square miles in the province of Ontario. The two districts are separated geographieally by the Ottawa river, and geologieally by at belt of sedimentary rocks about 40 miles wikle. The city of Ottawa lies between the two productive areas and is the seat of the mica industry-all the important works engaged in trimming and in otherwise preparing the mineral for the markets being located in that place.

Deposits of white mica, also, oceur in Canada, and oceurrenees of this variety (some few of which have been worked at various times), are known from Labrador in the east to the Rorky mountains in the west, while several Aretic expeditions have retumed with good specimens from the far north.

Though the average dimensions of mica sheets do not much exceed $3 \mathrm{x} 5$ inches, plates of enormous size are sometimes obtained. Crystals have been found which measured orer 4 feet across and weighed nearly two tons.

About 300 mines have been worked for mica at rarious times in Canada, but at the present day no more than 25 are in active operation. Among the large operator: may ise numed: The Cieneral Electric Company, of secheneetady, X.Y.. Webster \& Company, Ottawa; Blackburn Bros., (jttawa: Wallingforel \& Company, Ottawa: O’Brien \& Fowler, ottawa; Kent Bros., Kingston.

\section{Mineral Pigments.}

Ochres, wad and ferruginous clays, suitable for mannfacturing into paint , are found in many parts of Canarla. These mineral pigments, when raw or burnt, give a range of colours including golden ochre, vellow ochre, cimnamon vellow, siema, umber, Vandyke brown. Indian rexl, etc.. rete.

Though they have been emploved in small gutuntities, for localuse. in many districts, the commercial exploitation is limited, at present, almost entirely to the provinces of Quebec and ()ntario.

In Quebee there are mmerous deposits of ochre in the counties to the north of the st. Lawrence river, resulting from the dreomposition of iron prrites eontained in the rocks of the Laurentian hills. In the neighbourhood of Three Rivers much ochre of good quality is dug each year and manufactured into paint. Deposits are also being workel in Nicolet countr. on the opposite side of the sit. Lawrence.

In Ontario deposits of importance are found in various sections of the prosinee, including Algoma distriet and Norfolk, Iceels, and Halton counties. 
In Nasagawera township, Halton county, there is a deposit from which ochre is now lieing produeed in small quantitios.

In Noval ficotiat and New Brunswick, drposits of ferruginous elays and watel. as woll ats the oche deposits of Colchester eounty, Nova Scotia, have bern workerl on a small scale from time to time. In the western provinces, deposits of workible size and grarle are said to exist, but no production is reperterl.

\section{Rarytes}

Deposits of barytes (BasO) are found in commercial quantities distributel throughout northeastern Nova scotia at Lake Ainslie, Inverness county, North Cheticamp, Inverness county, Five Islands and Stewiake, Colchester county, and near River John, Pictou county. At the three latter places, deposits have proved to be pockety and difficult to work at a profit, but in the vicinity of Lake Ainslie the deposits have been found to be larger and more continuous, and sinee 1890 the shipments of this mineral have areraged nearly 2000 short tons per annum.

At Lake Ainslie, the barytes, with some caleite and fluorite, forms a series of roughly parallel veins cutting Pre-Cambrian felsites. The reins, though showing many irregularities in size, are fairly persistent, one nearly vertical vein having a width of from 7 to 14 feet for a depth of at least 250 feet. In sereral instances the reins locally attained thicknesses of 20 feet.

Although this mineral is mined only at Lake Ainslie, barytes deposits are known to occur at several other localities in Canada, the more important localities being: township of Hull, province of Quebec; in the province of Ontario in the townships of Bathurst and North Burgess (Lanark county), Mr Nab (Renfrew county), Drummer and Galway (Peterborough county), and Summerville (Victoria county). Large veins also occur on Jarvis, McKellars, and Pie islands in Lake Superior and also in northern Ontario near the headwaters of the Wanapitei river.

The produet of the mill in operation at Lake Ainslie is used in the paint manufacturing trade.

\section{Mineral Water.}

Spring waters containing minerals in solution, or, as they are usually termed, mineral waters, occur in very many sections of the country. Many of them are being utilized commereially, both as potable waters and for bathing purposes. At several of the springs, where the water has curative properties, hotels and sanitariums are being operated. Some of these are thermal or hot springs and are prineipally used for baths.

\section{Natural Gas.}

The oldest and, at the present time, the largest natural gas producing district in Canala is the territory bordering on the east and north shores of lake Eric. This area can at present be divided into several distinct fields, but the intervening areas between these fields are fast being drilled, and the results tend to show that in all probability the whole of this distriet is muderlaid by gas producing strata. In the counties of Haldimand, Welland, Esicex, and hont, large supplies appear to be available. In these counties the gas horizons are in the Clinton, Medina, Trenton, and Guclph formations. In Esiex, county, a single well, cirilled 1020 feet to a horizon in the Guelph formation, yielded gas at the rate of $10,000,000$ eubie feet per day. The gat from thic Ontario district is piped to all the larger towns in the southern 


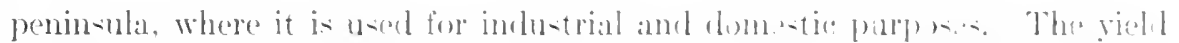

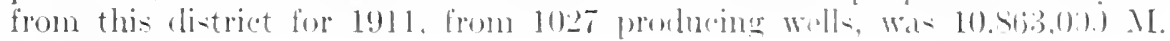
cubit feet.

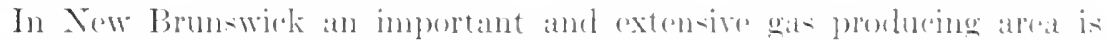

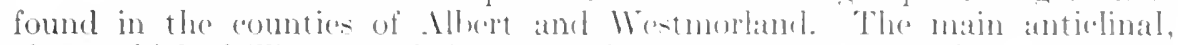

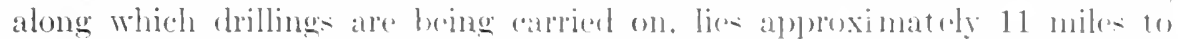

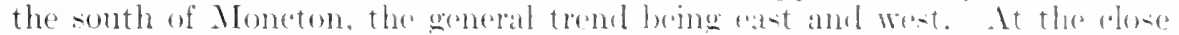

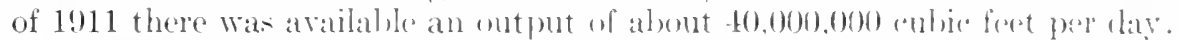
In the season of 1912 the fichl was further extencled and proverl he at number of additional wells. the total number of such holes now heing 23 . (Aach with a pressure at the collar of orer $100 \mathrm{lh}$ - perese ineh. At the present time the gas is being utilized to supply the towns of Moneton and Hillsborough, but it is proposed in the near future to furthere extenel the distribution.

In the province of Quebece, a number of wells were brilled in the vieinity of Three Rivers and the gas obtained from these wells was utilized locally for a short time, but operations have since been abandoned.

Natural gas is reported to have been encountered in sitsatcheran in wells drilled at Esteran in the southern part of the province.

Natural gas has also been found in northern Alberta along the Athabaska river. In the southern part of the province, in an extensive area of which Medicine Hat is the contre, natural gas has been found in the Niobrara formation in a number of wells drilled to a lepth of 1000 feet. Recontly: wells drilled on Bow island, 40 miles west of Mrodicine Hat, encomtered a strong flow of gas and this gas is being piped 170 miles to (algary, and also to Lethbridge. McLeod, and other towns in southem Alberta. The gas possibilities of the lower ('retaceous measures of Alberta and other western provinces, where eapped by the upper members of the series, and where they are not so deep as to be beyond commercial reach. may be considered to be exceptionally promising. and at the present time considerable prospecting is being carried on with a good measure of suceess.

The total production of natural gas in Canada for 1912 was $15,296,803,000$ cubic feet, ralued at $\$ 2,362,700$.

\section{Peat.}

The peat deposits of Canada are quite extensive and constitute an important reserve of fuel that has as ret been but little utilized. The most important areas so far as known are those found in the provinees of Quebec and Ontario. A number of these have been systematically examined and survered by the Mines Branch with a riew to determining their character and extent. The Branch has also carrjed out a comprehensive investigation of the fuel ralues of peat. having built a plant in Ottawa for demonstrating the feasibility of the manufacture and use of peat gas in gas engines. During the past two years air dried peat fuel from the govermment bog at Alfred was sold in Ottawa, and peat from a privately owned bog at Farnham. Que., was disposed of in Montreal. In both cases the fuel was in considerable demand for use in open grates and in kitchen ranges. The Alfed bog is now being operated as a private enterprise and a consideralle production is anticipated. 


\section{Petroleum.}

At the present time the prineipal oil fields in Canada are situated in the peninsula of southwestern Ontario, between Lake Huron and Lake Erie. The first oil was found in Lambton comnty in 1862, and active prorluction las been continued erer since. Until 1907, the Lambton County fields in which there have been about 11,000 producing wells were by far the largest problucers; since then, soveral new districts have been opened up, the most proninent ones being the Tilbury distriet in Kent county and the Onondaga district in Brant county. The oil districts are all situated within an area underlain ly Deronian strata, usually on an anticlinal axis, and the petroleum is largely obtained from horizons in the Onondaga formation at deptho varying in the difforent loealities. When the wolls are first drilled, the natural pressure is usually sufficient to force the crude oil to the surface, sometimes producing what are known as gushers. After the flowing period, the oil has to be pumped. While some of the smaller distriets became exhausted in a few rears, many of the pools being only a few hundred feet wide and perhaps a cuarter of a mile long, others have continued to furnish oil for a long period.

Four refining companies are operating in Canada distilling about 10 million gallons of Canadian crude oil per year, but the greater part being distilled at these refineries is still being imported from the United States. The total production for Canarla for the year 1912 was 243,336 barrels valued at $\$ 345,0.50$.

In New Brunswick, in the clistrict lying 11 miles to the south of Moncton, oil is being pumper in small quantities from the holes which produce the gas of this district. Although the production so far is not large, drill holes are continually being sunk, and it is hoped that very shortly astronger and more continuous ricld will be the result.

In Alherta, although oil has not been encountered in commercial quantities, prosureting for it is being carrier on vigorously, and there is every probability that this province will be added to the list of producers at a very carly tate.

In eomnexion with the oil industry in C'anada, mention should be made of the existence of extensive deposits of bituminous shales and tar sands.

Beds of bituminous shales, as at present reeognized, are found in Gaspe, New Brmmick, and Nova Scotia. Those in New Brunswick are without question the most important. They occur in the counties of Albert and Westmorland anf extend in an easterly and westerly direction over a distance of 40) miles. During the past 10 months extensive exploration, by means of diamond brilling and surface work, has demonstrated not only the quantity hut the quality of these valuable deposits. It is anticipated that in the nur future a plant, with a eapacity for an initial daily treatment of 2000 tons of shale, will vield approximately 80,000 gallons of erude oil per day.

Tar sinds are known to occur in Alberta along the Athabaska river for a distanee of upwards of 100 miles north and south of Fort Medurray. Althongh the "xistenee of these deposits has been recognized for many years, no strps have as yet been taken to accurately determine their possibilities.

\section{Phosphate.}

('anada at one time produeed large quantities of mineral phosphate, or aldatite, the output in 1890 amounting to nearly 32,000 tons. In this year, howerer, the competition of foreign eountries, more particularly the southern 
United States, caused a decline in the price of the mineral, with a consecuent falling off in production in Canada. The annual ontput has continued to decline, mitil, at the present time, the average production falls short of 1000 tons a year. irastically the whole of this amomt is obtained as a by-product in the mining of nuca-the two minerals ocemrring in close association in many of the mines. What has been said as to the distribution of the amber mien deposits in ("anada, under the head of "Mica," applies also) to the oceurence of phosphate. The greatest phosphate producing area in Canada, however, was the Lierre River distriet, in the eomenty of Ottawa, province of Quebec. A very rich belt of phosphate-bearing rock traverses this region and has been exploited in the past by a number of important mines, all of which have been closed down for a number of years.

The phosphate deposits of canala are fomel ascoedated with a rery old series of rocks, prineipally granite and gneiss in which the apatite occurs in the form of veins and pockets. These bodies are very irregular in size and shape and are rery difficult, as well as expensive, to mine, owing to the fact that large quantities of dead rock have to be handled in order to secure a relatively small amount of phosphate. The deposits of the southem United States, on the other hand, as well as those of Tunis, Algiers, and most other phosphate-producing countries, are of a sedimentary nature, and oceur close to, if not actually at, the surface of the gromul. These heds can be easily and cheaply exploited with the aid of steam-shovels and dredgesa course which it is impossible to pursue in the ase of canadian deposits. In spite of the large quantities of apatite which have been taken from the old phosphate mines in canarla. the deposits are believed to be still rery extensive, and they would doubtless be worked again, should a new use be found for the mineral or should prices warrant it.

The sole uses to which mineral phosphate is put at the present time are the manufacture of phosphorus and fertilizer.

Nearly all the phosphate now produced in Camada is consumed at the town of Buckingham, Que., where two works have been established to treat the mineral, namely: the Electrie Reduction ('ompany, engaged in manufacturing phosphoris, and the Capelton Fertilizer ('ompany, making phosphatic fertilizer.

\section{Pyrites and Sulphur.}

Native sulphur is not known to oceur in Canada in deposits large enough to be utilized commercially. The ehief domestie souree of sulphur for industrial uses is the mineral pyrites, which, in the pure state, eontains $53.54{ }_{0}$ sulphur and $46 \cdot 66^{\circ} \%$ iron.

Important deposits of iron pyrites oceur in Quebee in the sherbrooke district; in Ontario in the Hastings district of central Ontario, and at a number of localities east and northwest of Lake superior. Other deposits have been found in the northern part of British columbia at Ciranby bay and near Port Essington on the Slicena river. Deposits of pyrrhotite, a closely related, mineral containing, when pure, about $399^{\circ}$, of sulphur, also ocen in the southwestern part of Xew Brunswiek, in Queber, and in Ontario.

In Quelece, active mining operations have been carried on continuously for more than thirty years; the first prrites used in a suphuric acid plant in Ameriea is said to have come from the Eustis mine in this province. At present there are two producing mines; the total output is about 65,000 tons containing about $42 \mathrm{C}$ sulphur. About onc-half of this is used in Canada for the manufacture of sulphurie aciol; the halanee is shipped to the Cuited States. The Quebec prrites contains a small quantity of eopper and a little 
gold and silver, all of which are rocovered by troating the einder residues obtainos in the arol work where the sulphur eontent is recorered.

In (Ontario fon prites mines are prochering ore, two in the Hastings district, one north of Lalke Superior and one northwest of fort William. somo of this ore is used in sulphuric aciol plants in Canada, the balance is shipped to the United States. In ardition to the operating mines, there are sereral properties upon which diamond drilling has shown the existence of laree hodies of pyrites. In the Sullbury district of Ontario, huge ore Jodles of massire prrrhotite are being mined as ores of nickel and copper. These ores are treated by roasting in open heaps and then smelting in blast furnaces. No attempt is made at present to utilize the sulphur content of these ores because it would cost more to save the sulphur than it is worth. 'There is probably nearly $100,000,000$ tons of this ore available, and in the future it may prove profitable to save a portion of the sulphur. There are also numerous pyrites prospects in the province of Ontario, some of which may prove to contain valuable deposits of pyrites.

Pyrites ores in British Columbia are not mined for their sulphur content. The only location that has been thoroughly explored is that at Granby bay, about 110 miles northeast of Prince Rupert. Here development work has shown the existence of ore bodies containing in the aggregate about 12,000,000 tons. Preparations are being made to mine this ore and smelt it in waterjacketed blast furnaces to recover its copper content. The sulphur it contains will not be saved beeause there is no market for it on the Pacific coast.

\section{Salt.}

Extensive beds of salt or salt producing springs are found in nearly every province of the Dominion of Canada.

The largest, and, at present, the only producing district, is situated in the southwestern peninsula of the province of Ontario, bordering on Lake Huron, the St. Clair river, Lake St. Clair, and the Detroit river. The salt here exists as bels in the Salina formation of the Silurian system, which formation in the productive area is covered by upwards of 1000 feet of other strata, chiefly Devonian.

In this district, the principal plants are located at Windsor, Sarnia, Sandwich, Goderich, Clinton, and Kincardine. A prominent feature of the salt produced from the brine in Canada is its remarkable purity and also its freedom from other salts detrimental to its use in the production of caustic soda and bleaching powder. There is a good opportunity for the soda inllustry in the Dominion and it is assuming larger proportions each year. At Sandwich, a plant has been recently erected for the manufacture of caustic sotia and blaching powter from the brine.

The production in Canada is obtained wholly from the evaporation of salt brines, (ather natural or else formed by the pumping of water down drill holes to the silt bets and the re-pumping of the water when it has become a saturated solution.

In Tora Scotia salt springs have been noted from time to time and endeavour has been marle to turn these brines to commercial use. These springs come from the rocks of the lower Carboniferous series. The principal localities are in Antigonish county near Antigonish; in Inverness county near Whycocomagh; Cumberland eounty near Springhill; and in Hants (rounty near Walton. Strong brines were also encountered in bore-holes at elepths of 1400 and 1870 feet at Chererie in Hants county. 
In New Brunswiels, salt springs and known to ocent in the ricinity of

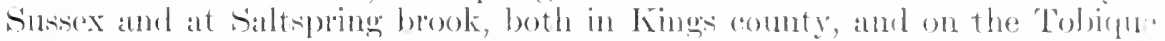
river in Victoria comnty. These springs, like those in Noval scotia, have their sonres in the lower' ('arboniferous l'ocks.

Manitoba furnishes hrine springs of varying strongth from the northwestem palt of Lake Winnipegosis, at salt point, near the mouth of the Bell rivel', which empties into Dawson bay. Salt springs also oecur on the Red Deer peninsulat in the southern part of Winupegosis lake. Salt was manufactured here as early as 1820 but of late yoars there has been no production.

Numerous springs have been noted from tine to time in the pratrie provinces, especially in the Mackenzie River basin, and numerous lakes in the district lying to the north of the Cypress hills in the southern part of the prairies are known to be saline.

In British Columbia, salt springs have been noted in sereral places, the principal one being at the north end of Admiral island near Nanaimo. The discovery of an important deposit of rock salt has recently been reported from Kivinitsa, astation about 45 miles east of Prince Rupert on the Grand Trunk Pacific railway. This discovery if confirmed will be of great practical importance to the matrine fishing industries established on the Pacific coust.

In the year 1912, the production of salt in Camada was 95,053 short tons, ralued at $\$ 459,582$.

\section{Talc.}

Tale or bodies of talcose mineral-in part steatite, or soapstone-hare been found at many places in the Dominion, but with the exception of the mines near Madoe, Ont., they have not been mined to any great extent. In Hastings, Frontenac, Lechls, and other counties in eastern Ontario, a number of such deposits have been discovered; and in Brome county, Quebec, as well as in the Eastern 'Townships and in the Maritime Provinces, steatite deposits of possible economic importance are known.

In the province of Ontario, near the village of Madloc, in Hastings county, a large body of tale has been worked for several years. There are now two mines in active operation and the annual production is about 8,000 tons. The value of the crude mineral is about $\$ 2$ per ton at the mine, while the ground talc from the mill arerages from $\$ 8$ to $\$ 10$ per ton.

Two mills have been erected, one at Madoc, and a smaller mill erected more recently near Eldorado, which are engaged in grinding the crude talc and preparing it for the trade. Most of the finished product finds a market in Canada, a large proportion being consumed in the paper industry. Other uses of the powdered mineral are in the manufacture of cosmetics, insulating coverings, dressing for leather, enamel paints, French ehalk, and as sizing for cotton cloths. Massive talc finds numerous uses because of its refractory qualities, its resistance to the action of most a cicls, and its possession of a high dielectric strength.

\section{Tripolite.}

In Nora Scotia and New Brunswick the bottoms of many of the small lakes are covered with tripolite, or, as it is also called infusorial earth, diatomaceous earth, fossil flour, keiselguhr, etc. This material is made up of the minute siliceous shells of diatoms mixed with small quantities of lime, alumina, and other impurities. 
The more important deposits, some of which have been worked, from time to time, are situated in Vietoria, Cumberland, Cape Breton, and Invernes connties. Noval scotia, and in Kings and st. John counties, New Brunswick.

At present only one company is actively engaged in Canada in the digging of tripolite and proparing it for the market. This company is earrying on it-operations at Bass River lake in Cumberland county, Nora Scotia.

Inposits of tripolite are also reported to oecur in Quebee, Ontario, and British Columbia, hut none of these have ever been worked, nor do they appear to be of immediate value.

The principal wes to which tripolite is put are as a polishing material, and in making non-conducting eoverings for steam pipes, etc. It is also userl as a filler in the manufaeturing of rubber goods, in the making of water filters, and hy paint manufacturers for making a wood filler. Before the introduction of wood pulp, as the absorbent for nitro-glycerine in the manufacture of dinamite, tripoli was used for this purpose.

\section{Cement.}

Materials used in the manufacture of cement in Canada include marls, limestones, clars, and blast furnace slag. The occurrence of eement materials Is: $x$ widespresd and abundant in all parts of the country that the question of their utilization is largely economic, being dependent upon the market for the product. the comparative arailability of suitable raw materials in lifferent localities, the cost of fuel, and the transportation facilities.

There are at present $2 t$ completed cement plants in Canada, with a total iaily capacity of about 28,800 barrels, besides several plants in course of constriction. The total production in 1912 was 7.132 .732 barrels, ralued at 59.106 .5 .56 , and in addition, 1.434 .413 barrels were imported.

The operating plants are distributed as follows: one at Sydney, Nova sicotial, using blast furnace slag, three in the province of Quebec, two of which are near Montreal. and one near Hull, adjacent to the eity of Ottawa, warh using local limestone and clay. In the provinee of Ontario there are fifteren plants with a total daily capacity of nearly 16,000 barrels. Of these 11 un marl and four limestone. The marl plants are loeated at Marlbank, burham. ()wen found, Lakefield, Hanover, Blue Lake, Raven Lake, Orangeville. and ()ttawid. The limestone plants are located at Belleville and Port ('ollberime.

Formerly" considerable quantities of "Natural Rock" cement were makle from a slitahle calcareous limestone found in the Niagara peninsula, hut this has now hern antirely superseded in Ontario by the production of Pertlame cement. In the provinee of Manitoba. a "Xatural Portland" rement is mallo at Babeock, sonthwest of Wimnipeg. Alberta has three limetone plants, lowated respertively at Calgary, Exshaw, and Blaimore. I reomel limestoms plant is being constructed at Blairmore, while a marl

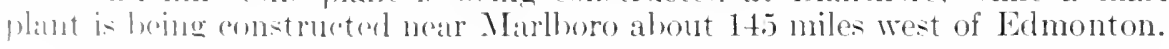

Britikh ('olmmbia has one rock plant at Tod Inlet, near Victoria, and a soromel mulk construction at the same place, while another rock plant is nearingerompletion at Princeton. 


\section{Clays and Clay Products.}

Clays or shales suitable for the manufacture of ordinary common and pressed huildling brick, pottery, tile, sewerpipe, etc., are found widely distributed in almost every provines of (aniala, and are being ntilized wherever there is a demand or a market for clay products. Fireclays or chass suitable for the manufacture of firebrick hare heen fomme at only a comparatively

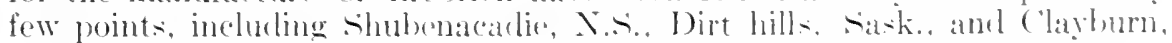
B.C.., and ats get are utilized to a comparatively limitorl extent only.

Kalin or china-clay has hex foumd in the comenty of Argentenil. provinee

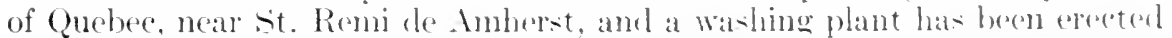
for the preparation of the material. The extent and importance of the elay working industry is shown by the value of the proclustion which in 1912 exceded $\$ 9,000,000$, and among-t non-motallie products was next in importance to coal. The consumption probably exceeds this value by at leat one-thirel, owing to the large imports particularly of firebrick and of earthenware and chinaware.

\section{Building Stone and Stone Quarries.}

There is searcely any raricty of stone which may not be used for huilding purposes. and in view of the great area and diversity in geological structure possessed by canadia. it is difficult to place and limitations upon the posibilities in the utilization of building stone and other quarry products. It may well be claimed that canada possesses in great abundance every kind of stone required for the purposes both of common and derorative architecture; these are only commercially arailable, however, in districts provided with transportation facilities and where comlitions respecting production are otherwise farourable for economic working.

A convenient elassification of building and other stone includes: (1) granite syenite ancess and other igneous pocks: (2) limestone and dolomite: (3) marbles: (4) sandstone: (5) slates.

At many ruarries partienlarly of granite and limestone, very large quantities of stone are crushed for use in making concrete and for other purposes, in fact the value of crushed stone produced is now greater than that of ordinary or dimension huilding stone.

At the present time quarries are being actively operated in the localities as shown hereunder:-

Granite is quarried in Nora Scotia, near Halifax and at Nictaux in Annapolis county; in New Brumswiek in the the rieinity of sit. Creorese, ( hatrlotte comty. and at Hampstead. Queens county: in Queber in the comties of Beauce, stanstead, Iberville. Portneuf, and Arentenil, while considerable quantities of srenite which is intrusive in limestone are quarred with the latter in the vieinity of Montreal. In (Intario, granite is quarried in the counties of Hasting- Idesk. Ontario, and the districts of Muskoka and Parry Sound: trap rock is quarried in the comnty of Peterhorough, ans! also near Bruce Mines, Algoma, and Port Arthur, Thumble bay. Mort of the quarries in British Colmmbia are on the west coast on Burrarel inlet. or on islands conveniently situated for tran-portation to Vancouver and Victoria. The total value of the production of erranite in 1912 was $\$ 1.373,119$.

Limestone is extensively quarried, not only as a huilding stone, but for

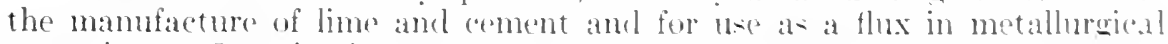
operations. Quarries in (atpe Broton, X.s., supply stome chiefly used for" 
fluxing in the iron and sterel furnaces at srrenry, while noar St. John, X.B, the output is used mainly in the manufacture of lime. There are numerous

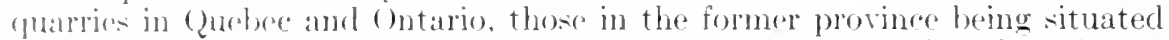
chiefly on the Istand of Montreal and in the near-ly counties of soulanges and sit. Hyacinthe, also in the counties of Portnenf and (queber, north and west of the city of (Queloee, and in the comty of Wright, near the city of Hull. In (matrio, limestone quarries are widely distributed through the whole of the sontlern portion of the proviner included broween the great lakes and ()tawa river, and particularly the more southerly portion of this area. In Manitobal the operating quarries are chiefly at Ciaron Quarry, Crunton, stonewall, Trmelall, andstony Mountain. In Alberta, limestone is quarried for lime lmming or cement manufacture at Frank and Blairmore in the ('rowsnest district, and at Exshaw and Kananaskis on the C.P.R. main line in the foot-hills of the Rocky mountains. At Fife, Boundary district, B.C.. limestone is quarried for use in the Trail smelter. The total value of the production of limestone in 1912, not including stone used for lime burning, or cement. was $\$ 2,762,936$. There was produced $8,475,839$ bushels of lime, valued at $\$ 1, \$+4.8+9$.

Marble is obtained in Quebec, at Philipsburg and South Stukely; in Ontario in the counties of Hastings and Lanark. A number of quarries not at present operating have also been opened in British Columbia. The value of the output of marble quarries in 1912 was $\$ 260,764$.

Sandstone.- Tery fine buileling stones are obtained in the counties of Cumberland and Pictou, X.S., and in Northumberland and Westmorland counties, N.B. In Ontario, sandstone is quarried in the counties of Carleton, Halton. and Peel. Several quarries have been opened in Alberta at Brickburn, Cilenbow. Rockburn, Rockilale, Stanton, etc. In British Columbia, sand-tone quarries are operated on Saturna. Fardington, and Denman islands. The total value of the production of sandstone in 1912 was $\$ 329.352$.

Slate.-Roofing slates have hern quarried at Danville. Corris. Brompton, Melbourne, and New Pockland in southern Quebec, the guarries at New Pockland having bren almost continuously operated since 1868. A new quarry has recently been opened up at Botiford in Temiscouata county. In the province of Ontario, some development work has been undertaken on a slate property, near New Liskeard in Hudson township. Roofing slate has also born olitained on the west coast of British Columbia. 


\section{STATISTICS OF MINERAL PRODUC'TION IN TIIE PROIINCES OF CANADA, WITH SOME YOTES ON THE MINING \\ LAIIS OF THE DOMINION OF CANADA AND \\ OF THE SEVERAL PROYINC'ES.}

A summary table of the mineral production in the whole of (anarlat has already been given in the introduction to this pamphlet, and further details of the record of production during the rears 1911 and 1912 in anch of the provinces ate given in tle following pages.

The conditions on which mining lands or mining rights may be acquired in Canada are not uniform throughout the country, but rary with the different provinces. This is due to the fact that, with certain exceptions, Crown lands and mining rights are owned or controlled by the provinces, and each province sells or leases mining lands or mining rights according to its own laws or regulations. The exceptions are, the provinces of Manitoba, Saskatchewan, and Alberta, the Yukon, and North West Territories, the public lands of which are still held by the Federal Covermment at Ottawa and are leased or disposed of under Dominion regulations. 
NOVA SCOTIA.

Area, 21,428 sq. miles. Population 1911, 492,338.

Mineral Production 1911 and 1912.

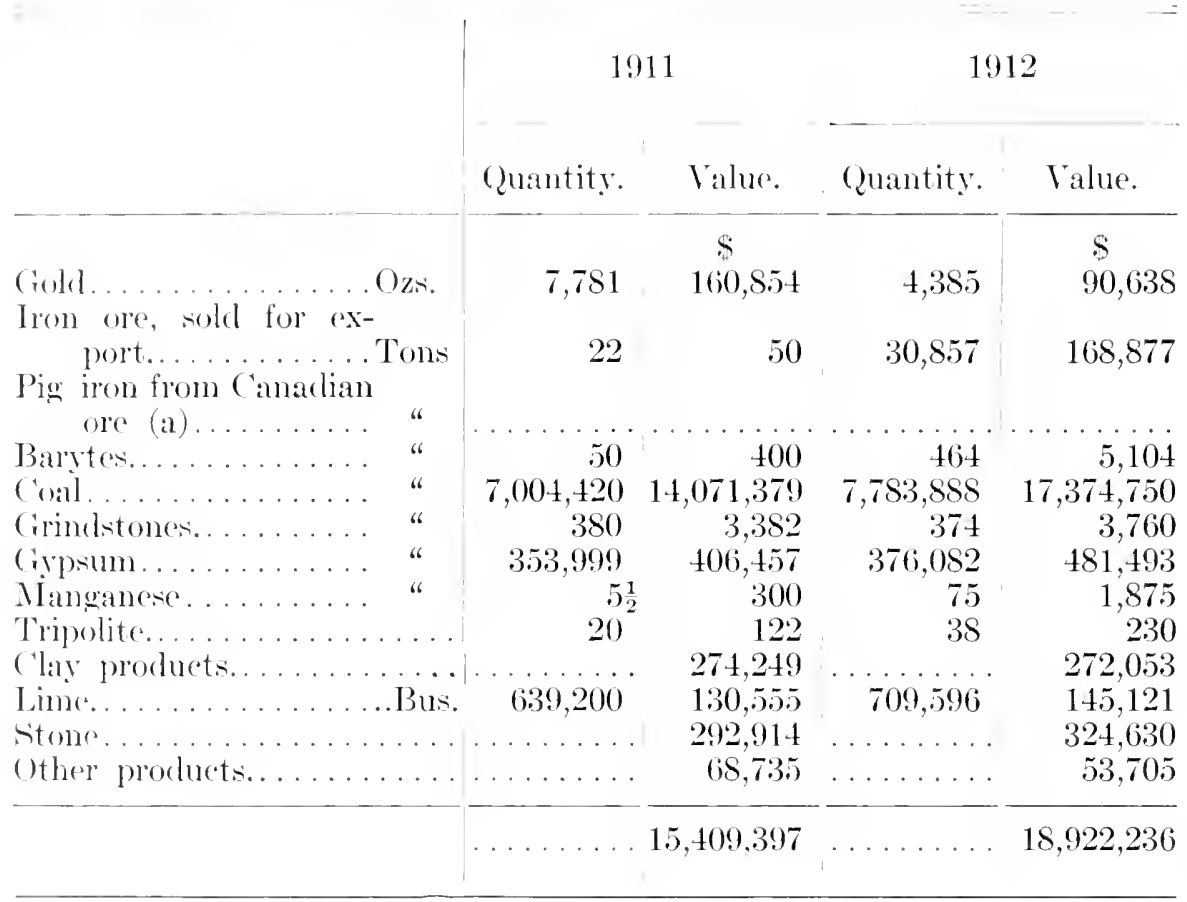

(a) Total production of pig iron in Nova seotia in 1911 was 390,242 tons, valued at $\$ 4,6 \$ 2,904$, and in $1912 \mathrm{w}$ as 424,994 tons, valued at $\$ 6,374,910$.

()ne of the smallest as well as one of the oldest of the Canadian provinees, Nora sicotia, has always been an important mining centre and her deposits of coal, gold, iron, and gypsum have been mined for many years.

situated on the Atlantic seaboard, the facilities for water shipment are mexeelled, and a very large industrial development has taken place in the irom and steel industry at Sydney, New Cilangow, and Londonderry based on thre locally arailable fuels, fluxes, and ores, as well as the iron ores of Newfouncliand.

()ther mincrals produced include tungsten, antimony, barytes, manganese, infusorial earth, arsenic; as well as elays, quarry products, cement, limm, ete.

Prospecting and mining rights are granted direet from the Crown under the "Mines Art" (Chapter is of the Rerisod Statutes of Nora seotia 1900 and anomelusents thereto), while mining is earred on under the regulations provirkel in the " "oal Mines Regulation Act," and "The Metalliferous Mince Remendations Arot." 
Nova Seotia furnishes eneouragement and assistance to the mining industry by providing core drills owned by the Department of Mines and made available to applicants under certain conditions and regulations for the prospecting or development of mining lands.

Copies of the Mining Laws, Regulations, mine reports, maps, and other literature, may be obtained from the Commissioner of Public Works and Mines, Halifax, Nova Scotia. 
NEW BRLNSWICK.

Area, 27,985 sq. miles. Population 1911, 351,899.

Mineral Production 1911 and 1912.

1911

1912

Quantity. Value. Quantity. Value.

\begin{tabular}{|c|c|c|c|c|}
\hline & & s & & s \\
\hline Iron ore, sold for ex- & 31.120 & $69+64$ & 71.520 & 127.716 \\
\hline Coal............. & $.5,781$ & 111,562 & 44,780 & 89,560 \\
\hline Grindstones......... " & 4,186 & 49,560 & 4,038 & 48,330 \\
\hline Gypsum.......... " & 93,205 & 115,044 & 82,757 & 185,821 \\
\hline Minera! water............ & & 19,843 & & \\
\hline Natural gas........... M. ft. & & & $173,90: 3$ & 36,549 \\
\hline Petroleum . . . . . . . . . Bls. & 2,461 & 3,019 & $2,6 \pi 9$ & 3,799 \\
\hline Clay product.............. & & 38,000 & & $5+, 910$ \\
\hline Lime. . . . . . . . . . . Bus. & 613,728 & 132,897 & 616.835 & 133,742 \\
\hline Stone*............... & & 73,441 & & 90,577 \\
\hline & & 612 & & 771,004 \\
\hline
\end{tabular}

* There is also an important production of cut and polished granite at st. George from both imported and local stone of which the value in 1911 was $\$ 86,65 \mathrm{~S}$ and in 1912 $\$ \$ 2,935$.

Crypsum, coal, iron ore, manganese ore, sandstone abrasives, natural gas, petrolemm, oil shales, together with limestone and building and ornamental stones of granite and standstone, form the principal mineral resources of this province, although the occurrence of many other minerals has been noted.

Propecting and mining licenses may be taken out under authority of the " (inneral Jining Act" of the province of New Brmswick. Information respecting licenses, mining regulations, royalties, etc., may be had from the cinregor Cieneral, Department of Crown Lands, Fredericton, New Brunswick: 


\section{PRINCE EDWARD ISLAND.}

Area, 2,184 sq. miles. Population 1911, 93,722.

This little province, consisting of the island of the same name in the Gulf of St. Lawrence, has practicilly no mineral industries. It is uniformly fertile and well peopled and has important fisheries. Red sandstones suitable for masonry may be quarried in some places, and clays occur that may be used for brick-making. It may be that coal-seams underlie the island or some part of it, but if so, they appear to be at a depth too great for utilization at the present time. 
QUEBEC.

Area, 706,834 sq. miles. Population 1911, 2,002,712.

Mineral Production 1911 and 1912.

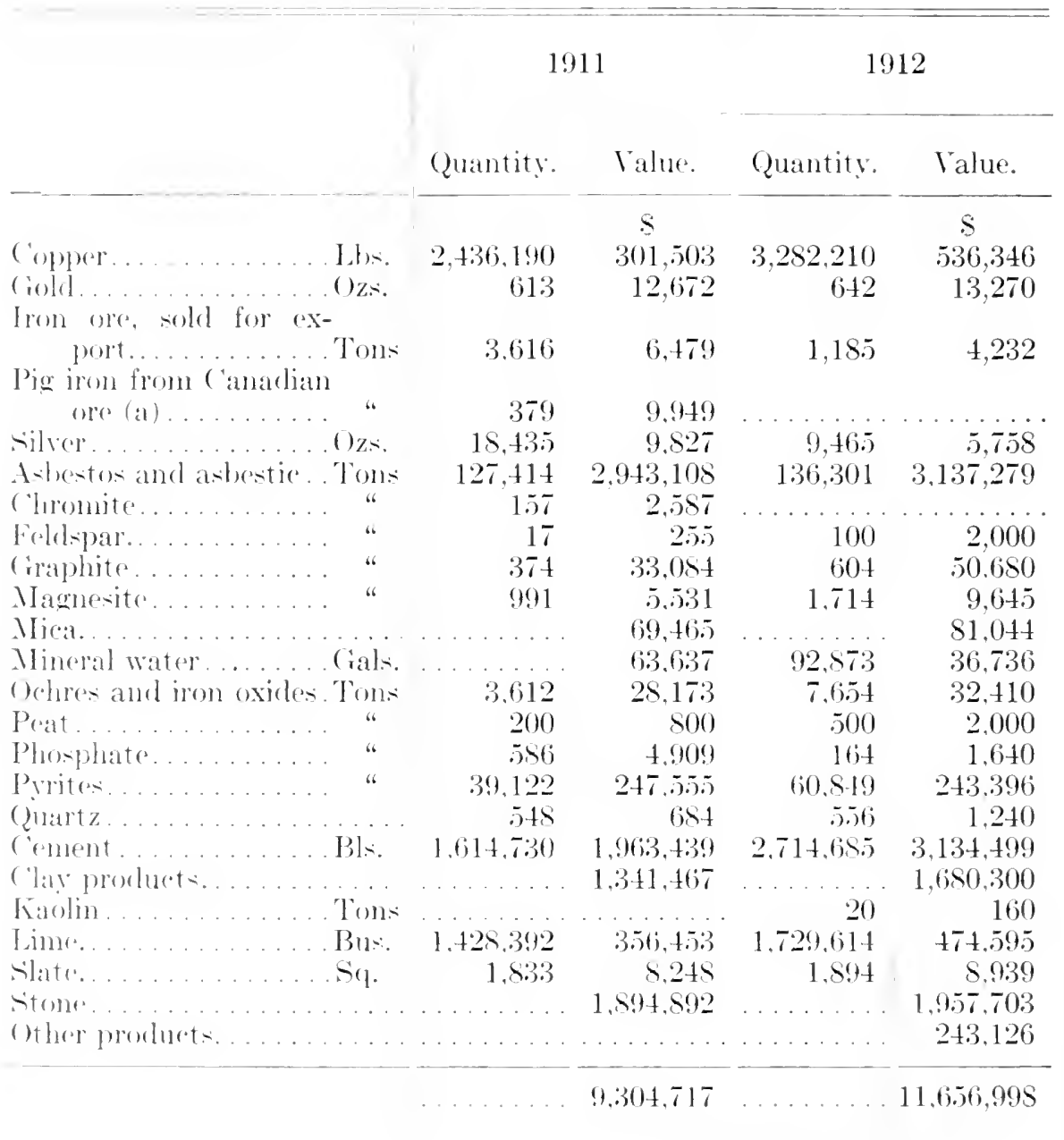

(i:) There was no production of pig iron during 1912, while in 1911 the total prorluction wats fi.js tons, valuerl : $\$ 17,2 \times 2$.

There was also in this provine an important production of aluminimn from importend ores.

This provines with its boundaries resently extended to include the great north comentry of Lneava, reaching to the shores of Hudson bay and Hudson strat, is now geographically the laresest province in canarla, but as in all of the rentral and western proviness, the settled or populated section is con- 


\section{5}

fined to a comparatively narrow fringe of territory along the southern border, and the greater part of the northern area is scarcely erem explored.

Quite a wide variety of mineral produets are obtained as will be noted in the above table. In the southeastern portion of the provinee, south of the st. Lawrence river, in an area wsually reforred to as the "Esistern Townships", are found alluvial gold deposits of Besules county, copper prerites, asbestos, and ehromite deposits. bog iron ores, and larese marble and grante quarries. North of the st. Lawrence are bog iron ores at Three Rivers, etce, and titanium ores north of Montreal, while farther west, north of the Ottawa river, are found magnesite. graphite, phosphate, foldspar, miea, iron ore, molybdenite, with lead and zine at calumet island and near Lake Timiskaming.

Miners' certifieates, mining lieenses, and mining concessions are granted by the Provincial Govermment under authority of the "Quebec Mining Law Act" of 1892. With amendments: and all information desired respecting the mines, mineral resources, and mining laws of the provine may be obtained on application to the superintendent of Mines. Burean of Mines, Department of Colonization, Mines and Fisheries. Quebec City, Queber. 


\section{ONTARIO.}

Area, 107,262 sq. miles. Population 1911, 2,523,208.

Mineral Production 1911 and 1912.

1911

1912

\begin{tabular}{|c|c|c|c|}
\hline Quantity. & Value. & Quantity. & Talue. \\
\hline & $\because$ & & \\
\hline $\begin{array}{r}7,932.263 \\
2.062\end{array}$ & $\begin{array}{r}2.219 .297 \\
42.625\end{array}$ & $\begin{array}{r}22,250,601 \\
86,523\end{array}$ & $\begin{array}{l}3,635,971 \\
1,785,596\end{array}$ \\
\hline
\end{tabular}

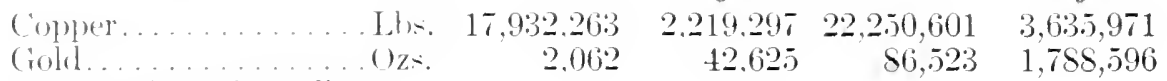

Pig iron from Cinadian

$$
\begin{array}{rrrrr}
\text { ore (b) .......... Tons } & 41.807 & 603,4.55 & 36,35.5 & 450,886 \\
\text { Iron wre colil for export. ". } & 5.379 & 12.57 & 14,567 & 28,125
\end{array}
$$

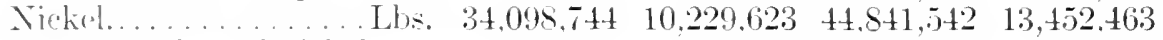

(o) oxlt oxicle and nickel oxide.......... " $154,17 t$

Cobalt mineral et mixed cothalt and nickel oxide " $1,260,8: 32$

silver.......... Ozs. 30,540,7.54

Zine ore ......... Tons

Actinolite.......... "

Arsenious oxifle....... "

Coruntum.......... "

Feldspar............ "

Fluorspar......... "

Graphite......... "

Gipsum........... “

Miea.

67
2,097
1,472
7,706
34
895
27,399

Mineral water.

221,690

$349,0.54 \quad 156,256$

$1,285,280 \quad 163,988$

$16,279,443 \quad 29,214,025 \quad 17,772,352$

$\ldots, \quad 10 \quad 3,750$

11: . . . . . . . . .

Tatural gas........... . ft. 10.863,st1

Ochres............... Tons

10

Peat.

"

Petroleum . . . . . . Bls.

Phosphate........ Tons

Purites

$1,26: 3$

(juartz . . . . . . . . . . . . .

288,631

3.5

$4.3,5+4$

59.978

sialt............... "

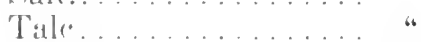

91.582

7.300

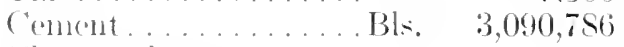

( 'lay products.

$3, \ldots, 0,1 \leq 6$

Lime. . . . . . . . . Bus. 3,360,26.)

Sind-lim brick....... No. 29,502,186

sitone. . . . . . . . . . . . . . . .

()ther prodiects.

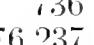

161.873

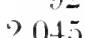

1,000

$\$ 9,262$

$1,960 \quad 239,091$

51,684

235

36,492

98,018

59.212

136.778

$1,807.513$

160

3.017

$3.5+.0 .54$

297

118.265

8. 3.181

443.004

13,633

28,916

40

240

1,456

66,442

53.119

176,056

62,932

131,529

$12,529,463$

2.036.245

2.100

$3,7+1,039$

$3,916,575$

538.902

237,662

892,305

408.110

900

200

341,251

240.657

20.677

70.689

99.686

193,976

9.5.0.5 3

459,582

8.270

23. 132

$3,044,713$

$3,372,897$

$4,864,700$

$3,376,193 \quad 573,269$

$36,371,002 \quad 328,548$

$1,109,164$

363.668

$42,796,162$

$51,985,876$

(1) The total production of pig iron in Ontario in I9 I I was 526,635 tons, valued at $\$ 7,606,939 ;$ in $1912,589,593$ tons, valued at $\$ 8,1,6,089$. 
Ontario now produces the largest output as well as the greatest variety of mineral products of any of the Canadian provinces, being credited with over 38 per cent of the total ('anarlian mineral production in 1912. The extent and variety of production is shown in the above tabular statement. The principal metalliferous ores are the niekel copper depositsof the sudbury district, the silver-colsalt-nickel ansendeles of the (cobalt and surromeling areals, the gold fieds of eastern (Ontario and of Porcupine and of numerous other widely sattered areas in the northern and wostern sections, and the iron ores of Hastings and Frontenate comnties, as well as those north and west of Iake superior. In the astern portions of the province are found impor tant deposits of cormudum, foldspar, fluorspar, graphite, mica, phosphate, pyrites, tale, lead and zine ores, ete. In the sonthern section, including a highly developed agricultural areat, are foumd the deposits of petroleum, natural gas, gipsum, and salt, this area also containing numerous stone quarries, lime kilns, and clay and cement plants, etc.

Iron blast furnaces are in operation at Hamilton, Deseronto, Midland, Sault Ste. Marie, and Port Arthur, while motallurgical works for the reduction of nickel, copper, silver, or lead ores are found at Copper Clitf, ('oniston, North Bay, Orillia, Thorold, Kingston, and Deloro, and eleetric furnaces for the production of ferro alloys are operating at Buckingham. Welland, and at Sault Ste. Marie.

The acquisition of mining elaims in Ontario depends in the first instance upon the discovery of valuable mineral. followed up ly staking and recording, performance and proof of work, and applying for a patent and paying a small price per acre, as per the conditions and regulations set forth in the "Mining Act of Ontario" 1906, and amendments thereto.

For the encouragement of metal refining, a small bounty is offered on the production of refined nickel. nickel oxide, cohalt, cobalt oxide, copper sulphate and on white arsenic from mispickel ores, under the conditions and regulations provided in the "Metal Bounty Refining Act."

Information respecting miner's' licenses, mining laws, provincial bounties, reports of the Burean of Mines, ete., may be had on application to the Deputy Minister of Mines, Department of Lands, Forests and Mines, Toronto, Ontario. 


\section{MANITOBA.}

Area, 251,832 sq. miles. Population 1911, 455,869.

Mineral Production 1911 and 1912.

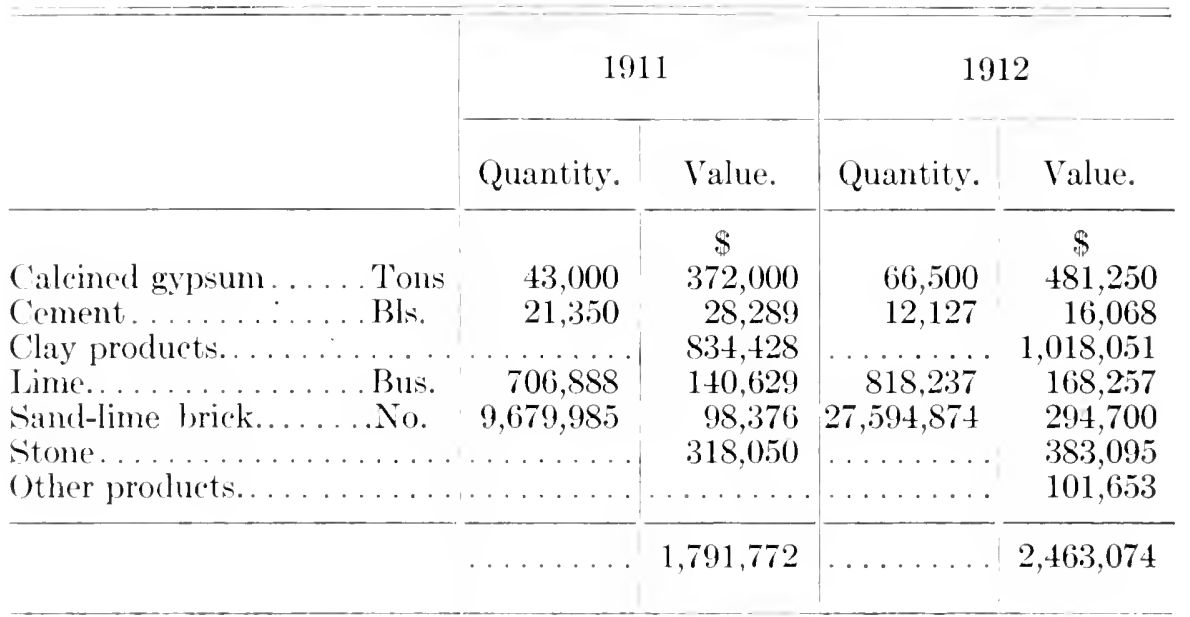

Outside of clay and quarry products, gypsum is the only mineral being mincd in Mamitoba although the oceurrence of gold has been noted, and gold claims are being exploited on the southeastern border of the province adjoining the Ontario boundary and in an area immediately east of Lake Winnipeg. Sialt was for many years produced in small quantities from brine near lake Wimnipegosis. There is also a considerable lignite coal field near the sonthern boundary of the proxince, but mining operations are not being conducted thereon.

The Crown lands, including mining rights in the provinces of Manitoba, Sakatchewan, Alberta, and the Yukon, and North West Territories are owned and controller by the Dominion Government, and reference to the laws in fore regarding the disposal of mining lands will be found under North West Territories. 
SASKATCHEWAN.

Area, 251,700 sq. miles. Population 1911, 492,432.

Mineral Production 1911 and 1912.

1911

1912

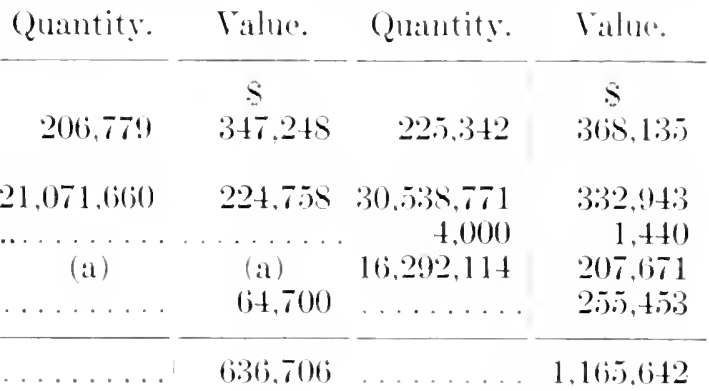

(a) In I91, included in other products.

The provinces of Manitoba, siskatehewan, and Alberta, enbrateing an enomons area of comparatively lesel prairie land, are popularly known

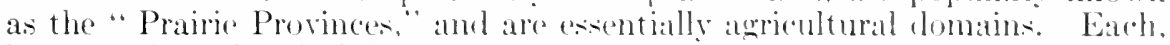
however, is underlain by important coal arous consisting of lignites in Manitoba and saskatchewan, and (hanging to bituminoms and semi-antlurateites. as the Rocky mountains are approached. The raw materials for the mamufacture of brick, tile, and cement are found at a mumber of locelities in these provinces. Limestones and building stones: also oceur. The silskitrehewan lignites are mined at Esterim.

While the disposal of coal lande and mining rights generally, is mate by the Dominion govermment (see under North West Territories), coal mining operations are carried on under the regulations and inspection provided in the Coal Mines Regulation Ordinance of the province. 


\section{ALBERTA.}

Area, 255,285 sq. miles. Population 1911, 374,663.

Population in 1913 estimated at over 500,000.

Mineral Production 1911 and 1912.

1911

1912

Quantity. Value. Quantity. Value.

\begin{tabular}{|c|c|c|c|c|}
\hline & & 8 & & s \\
\hline$\ldots \ldots \ldots \mathrm{O}_{\mathrm{z}}$ & 10 & 207 & & 1,509 \\
\hline . . . . Tons & $1,511,036$ & $3,979,264$ & $3,240,577$ & $\$, 113,525$ \\
\hline Natural gatis. & 780,286 & $110,16 i)$ & $2.583,437$ & 289,906 \\
\hline C'encint . . . . & 512,176 & $1,241.535$ & 821,165 & $1,775,898$ \\
\hline Clay products. & & $1,052,751$ & & $1,356,184$ \\
\hline $\operatorname{Lim}(\ldots \ldots \ldots \ldots$ & 434,038 & 100.407 & 704,035 & 166,520 \\
\hline sand-lime brick ...... No. & $3,500,000$ & 20,000 & $10,732,000$ & 139,952 \\
\hline 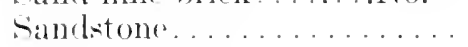 & $\ldots \ldots \ldots$ & $158,3+4$ & $\ldots \ldots \ldots$ & 81,391 \\
\hline Other products............ & & $\ldots \ldots \ldots$ & & 148,704 \\
\hline
\end{tabular}

The mineral resources of this province include: coal, natural gas, alluvial golel, and clay and quarry products. Although petroleum has not yet becen found in commercial quantities, its ultimate discovery seems to be confidently anticipated. The production of coal has increased very rapidly during the past fow rears, and it appears certain that Alberta will in the rery near future, be the largest coal producing province in Canada. Natural gas has been fouml over a wide area. In the north is an enormous area of tall sancls, the commereial value of which has not been fully determined.

As in the other prairie provinees, the disposal of mining lands or leases is mate by the Dominion government at Ottawa see under North West Torritories), while coal mining has been carried on moder the conditions inpesed hy thr "Provincial ("oal Mines Rogulation Act," 1906. This Act and all andendments thereto is repealed and superseded by "The Mines Act" of Mllyerta, asiented to March 25, 1913, and to come into force August 1,1913 . 


\section{BRITISII COLUMBIA.}

Area, 355,835 sq. miles. Population 1911, 392,480.

Mineral Production 1911 and 1912.

1911

1912

Quantity Value. (quantity. Vialue.

\begin{tabular}{|c|c|c|c|c|}
\hline Copper.............. & $3,5,279,5,5,8$ & $4,360,198$ & $50,526,606$ & $8,2,56,561$ \\
\hline$\ldots . . U_{2}$ & 238,496 & $+.930,145$ & $2.71,81.5$ & $5,2(0.5,48.5$ \\
\hline Lead. . & $2: 3,78+, 969$ & 827,717 & $35.7(3.3,176$ & $1,597,554$ \\
\hline$\ldots()_{Z s .}$ & $1,857,1+7$ & $1,005,924$ & $2,(\mathrm{i}) 1,002$ & $1,612,737$ \\
\hline Zinc ore. . & 2,590 & 101,072 & 6,405 & 211.399 \\
\hline Coal . . . . . . . . . . . . " “ & $2,5+2,532$ & $7,945,41: 3$ & $3,208,997$ & $10,028,116$ \\
\hline Gypsum............ & 780 & $1,85.5$ & & \\
\hline Mineral water....... & & $3, \overline{0} 00$ & & 4.200 \\
\hline Cement . . . . . . . . . Bls. & 401,000 & 601,500 & .71,539 & $767,0: 38$ \\
\hline Clay products............ & & $675,5(0) 5$ & & $99(;, 568$ \\
\hline Lime. . . . . . . . . . . Bus. & 351,014 & 117.756 & $517,32 !$ & 181,905 \\
\hline Sand-lime brick. ....... No. & $2,953,072$ & 23.889 & $5,458,412$ & 49,515 \\
\hline 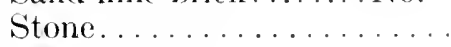 & $\ldots \ldots \ldots$ & 699,811 & & 779,611 \\
\hline Other products........ & & & & $385,9+6$ \\
\hline
\end{tabular}

$21,299,305$

$30,076,635$

For many years British Columbia was the premier mining province of Canada, and was only displaced in so far as magnitude of output is concerned in 1907, when Ontario forged ahead. In a certain sense, this province is still of first importance owing to the fact that mining is probably its most important industry. Physiographically the provinee embraces a series of mountain ranges beginning at the Rocky Mountain range forming the eatern border, and extending to the Pacific coast, the principal faatures of which have already been described in the introductory chapter.

Coal and metalliferous ores including gold, silver, copper, lean and zine, together with clays, building stone, and gypsum, constitute the chief mineral resources. Antimony, plitinum, molyblentme, and meroury are also founcl.

With the exception of the placer gold mining of the Cariboo district, active productive mining operations are at present confined principally to the extreme southern portion of the province and to a district on Vincourer island, and on the coast. The chief centres of activity are the Crowsnest coal mines, the metalliferous mines of East and West Kootenay, of which Movie, Ainsworth, Slocan, Sandon, Nolson, and Rossland are important centres, and the Boundary district, including Grand Forks, Phoenix, (ireenwood and Hedley, Britaninia bay and Texada island on the coast and Nan- 
aimo and ('omex on Vancouver islancl. The Portland Canal elistrict has recently assimmed considerable importance.

Much prospecting and development is being undertaken at many points on or near the coast, while the construction of the Grand Trunk Pacific railway will provide easy aceessis to a number of distriets in that portion of the interior which it traverses.

Important smolting industries have been established at Nelson, Trail, Cirand Forks, (ireenwood, in the southern interior, and at Ladysmith on the coast, the fuel for which is provided by the coal mines of Comox, the Crownest, or of Alberta. A new eopper smelting plant will be in operation at Anyox or Gimby bay, in December, 1913.

Mining locations are aranted under the laws of the province to discoverers, for nominal fees, and absolute titles may be obtained by developing such properties. The mining laws include a "Placer Mining Aet," "Mineral Act," "Inspection of Metalliferous Mines Aet," "Coal Mines Act," "Coal Mines Regulation Aet," etc., and full information respecting miners' certificates, the mining law and regulations, mining reports and maps, etc., may be obtained on application to the Provincial Mineralogist, Victoria, British Columbia. 


\section{YUKON DISTRICT.}

Area, 207,076 sq. miles. Population 1911, 8,512.

Mineral Production 1911 and 1912.

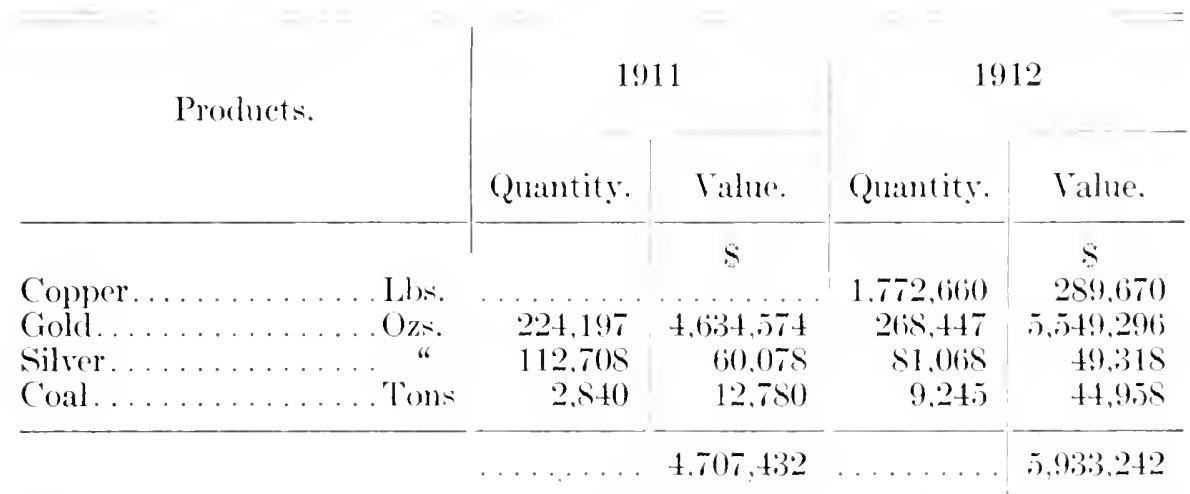

This district, which geographically is a continution of the great Rocky Mountain range extending northwesterly from the b0th degree of latitude, the northern boundary of British (olumbia, to the 1+lst meridian. the Alaskan boundary, has already become famoms on ateromt of the kilomelike gold fields, situated in the vieinity of Diwson, on the Yukon river. Placer gold is still the principal mincral product, although there is an increasing output of eopper and silver ores and of eal. The districet also possesses important coal ficlds. Fold ores and ores of copper, silver, leatl, and antimony have been foumd widely distributerl, and the region undeubstedly posseswes enormons mining posililitios.

The ('rown lands and mining rights are controlled by the Dominion govermment at ()ttawia and disposed of or leased alecording to the peralat ions in force and referred to munder North West Territories. 


\section{NORTH WEST'TERRITORIES.}

\section{Area, 1,242,224 sq. miles. Population 1911, 17,196.}

The North West Territories, as at present constituted, inelude all that northern portion of Camada above the 6oth parallel of latitude, extending from Ihudson bay on the past, to the Yukon district on the west, and including all of the northern Aretic islands that belong to canada. It is pratctically umpopulated, except for a few Indians and fur traders.

Little is known of the country beyond what has been learned from a few explorations of some of the prineipal rivers. In respect to its mineral resourees, the oceurrence of coal in the Mackenzie basin and of native copper in the (oppermine River distriet has long been known. Alluviat gold has been found on many of the streams, while the oceurrence of iron ores, mica, graphite, salt, and gypsum, havebeen noted. The northern part of North America and the great Aretic Archipelago to the north of this continent, contain large areas of the older rocks in which metalliferous and other minerals wilf no doubt rentually be developed, but in regard to which little is yet known.

As lats alrealy been explained, the ownership of Crown lands and mining rights in the North West Territories and the Yukon district, and in the provinces of Manitoha, Saskitchewan, and Alberta, are still retained under the control of the Dominion government at Ottawa. With the exception of the "Yukon Placer Mining Act" and amendments, no statutory mining law has been cnacted by the Dominion government although a proposed general Act is at present under consideration. The disposal of mining lands or leases is made under the "Yukon Placer Mining Act" above mentioned, and under regulations provided and approved by Order in Council.

Following is a list of the regulations in force at this date (May, 1913);--

\section{Statutory Act.}

"Yukon Placer Mining Act" and amendments.

Regulations approved by Order in Council:-

Dredging regulations, Yukon Territory.

Regulations governing the issue of leases to dredge for minerals in the sulmerged beds of rivers in Manitoba, Saskatchewan, Alberta and the North West Territories, excepting rivers in the Yukon Territory.

Regulations for the disposal of fuartz mining claims.

These regulations shall be applicable to all minerals defined as such on

Dominion Lands, situated clsewhere than in the province of British ('olumbia.

('oal Mining Regulations:-

Regulations for the disposal of coal mining rights, which are the property of the Crown in the provinces of Manitoba, Saskatchewan and Alberta, the Yukon Territory, the North West Territories, the Railway Bolt in the provinee of British columbia, and within the tract eontaining three and onelalf $\left(3 \frac{1}{2}\right)$ million acess acouired by the Dominion government from the provine of British Columbia, and referred to in sub-section (b) of section 3 of the "Dominion Lands Act." 
Regulations for the issue of permits to mine coal on lominion I ands for domestic purposes only.

Regulations for the disposal of petrolem amd natural gats rights, the property of the ('rown in Manitoba, Saskatchewan, Alluerta, the North IV Test Teritories, the Yukon Territory, the Railway Bolt in the province of British ('olmmbia, and within the tract containing thres and ons-half $\left(3 \frac{1}{2}\right)$ million aceres of lamel acepuired by the Dominion govermment from the provine of British columbia, and referred to in sub-section (b) of section 3 of the "I)0minion Lancls Act."

Regulations for the leasing and anministration of lands contaning linestone, granite, slate, marlsle, gypsum, marl, gravel, samel, clay, or any building stone, in the provinces of Manitoba, Saskatchewan, and Alberta, the North Went Territories, the Railwaty Bolt of British Cohmbia and Dominion Forest Reserves and Parkis. ote.

Regulations governing the issue of permits to remove sancl, stone, and gravel, the property of the (rown, from the beds of rivers and lakes in Manitolia, Saskatchewan, Alberta, the North West Territories, and within the Ratway Belt in the provinees of British ('olumbia.

Full information regarding Dominion mining laws and regulations may be obtained from the controller, Yukon and Mining Lamels Branch, Department of the Interior, Ottawa, or from any. Dominion Land Agent.

Summary of the Mineral Production by Provinces in 1912.

\begin{tabular}{|c|c|c|c|c|}
\hline Province. & Mrotallic. & $\begin{array}{l}\text { Non- } \\
\text { metallic, } \\
\text { except } \\
\text { claty and } \\
\text { stono } \\
\text { guatry pro- } \\
\text { ducts, ete. }\end{array}$ & $\begin{array}{l}\text { Clay and } \\
\text { stome } \\
\text { quarry pro- } \\
\text { duets and } \\
\text { othere } \\
\text { structural } \\
\text { minterials. }\end{array}$ & Total. \\
\hline & $s$ & 8 & $s$ & $s$ \\
\hline Nora S'cotia... & $2.59, \pi)$ & $17,867,212$ & 795,509 & $18,92 \cdot 2.236$ \\
\hline New Brunswick. & $12 \pi, 7] 6$ & $3(54,0.59$ & 279,2299 & 771.004 \\
\hline Quebec.... . . . . & 559,606 & $3,598,070$ & $7.499,3,322$ & $11,6.56,998$ \\
\hline Ontario..... & $37,452,387$ & $3.921,243$ & $10,612,246$ & $51,98.5,876$ \\
\hline Manitolsa... & $\ldots \ldots \ldots$ & 481.250 & 1.981 .524 & 2.463 .074 \\
\hline Saskatchewan. & & 368,135 & 797.507 & $1,16.5,6+2$ \\
\hline Alberta......... & 1,509 & $8,40: 3,4: 31$ & $3.66(5.6+9)$ & 12.073 .589 \\
\hline British (olmmlia. . & $16.883,736$ & $10.0: 32.316$ & 3.160 .583 & $30.07(6.6335$ \\
\hline Yukon. . . . . . . . & $\pi .588 .284$ & $41,9 \mathrm{i} \mathrm{S}$ & $\ldots \ldots \ldots$ & $5.933,242$ \\
\hline
\end{tabular}


Annual Mineral Production in Canada since 1886.

\begin{tabular}{|c|c|c|c|c|c|}
\hline Yrar. & $\begin{array}{l}\text { Value of } \\
\text { procluction. }\end{array}$ & $\begin{array}{c}\text { Talue } \\
\text { per } \\
\text { capita. }\end{array}$ & Year. & $\begin{array}{l}\text { Value of } \\
\text { production. }\end{array}$ & $\begin{array}{l}\text { Talue } \\
\text { per } \\
\text { capita. }\end{array}$ \\
\hline & $S$ & $S c$ & & $S$ & $\$$ c. \\
\hline 1SS6. & $10,221.25 \%$ & 2.23 & $1900 \ldots$ & $64,420.877$ & 1204 \\
\hline 1857. & $10,321,3: 31$ & 223 & $1901 \ldots$ & $6 . \overline{5}, 79 \overline{6}, 911$ & 1216 \\
\hline 18SS & $12,518,894$ & 267 & 1902. & $(0.3,2.31 .8 .36$ & 1136 \\
\hline 1859 & $14.01: 3,113$ & 296 & 1903. & $61,7+0,513$ & 1083 \\
\hline 1890 & $16,763,3,3,3$ & 350 & $190+$. & $60,082,771$ & 1027 \\
\hline 1891 & 18.976 .616 & 392 & 1905. & $69,078.999$ & 1149 \\
\hline 1892 & 16.623 .41 .5 & 339 & 1906. & $79,286,697$ & 1281 \\
\hline 1893 & $20,035,082$ & +0.4 & $190 \%$ & $86,865,202$ & 1375 \\
\hline 1894 & S51.19.931 & 398 & 1908. & $8.5,557,101$ & 1316 \\
\hline 1595 & 20.505 .917 & +05 & 1909. & $91,831.441$ & 1370 \\
\hline 1896 & $22.47+2.56$ & 438 & 1910. & $106.823,623$ & $1+93$ \\
\hline 1897 & $28.48 .7,023$ & $5 \quad+19$ & 1911. & $103,220,994$ & $1+42$ \\
\hline $1 \mathrm{~s}, \mathrm{~s}$ & 38.112 .431 & 732 & 1912. & 135.048 .296 & 1827 \\
\hline 1899 & $49,234.005$ & 927 & & & \\
\hline
\end{tabular}

\section{Bounties on Mineral Production.}

The Dominion govermment at the present time offors bomties on the presluction of petrolem and lead.

The bomty paiel on petrolem is at the rate of $1 \frac{1}{2}$ cents per imperial gallom on rorule petroleme produreed from wells in Canada, and the bounty is parahle moler the comblitions and regulations provided in the "Petrolem Bomity A.t."

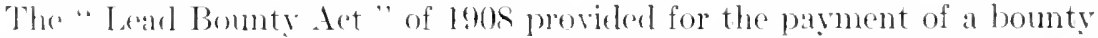
on lest containes in leasl ores mined in Canada and shippesl to a Canadian smelter, at the rate of 7.5 cents per hundred pounds or approximately $£ 310 \mathrm{~s}$ pere tom of $2.240 \mathrm{Ibs}$. subject to the restriction. that when the priee of lead

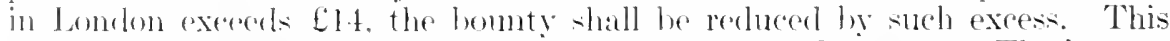
Aot has been renewerl in 1913 for a further periorl of five years. The bounty is payable subject to the terms of the Act anel of the regulations provided therementer.

Bomntion were formerly patid on the production of iron and steel, but these expirerl antomatically in 19)2 and have not been renewed.

Roference has alrealy hoen made in the remarks under Ontario to the bounty ofleres liy the ()ntario govermment on the production of cobalt niekel, renpers and arsenice.

The arlministration of the Dominion Bounty Acts is under the direction of the Minister of 'Trade and commeree, and full information in respect thereto may he hat from the Deputy Minister of Trade and commerce, ()ttawa. 


\section{Ore and Fuel Testing Plants.}

The Mines Branch of the Department of Mines has installeel, at ()t tawa, a modern and well requipped laboratory -The Dominion of Canada Ore Dressing and Metallurgical Laboratory-for the purpose of experimental eoncentration and metallurgieal tests with ('anadlian ores and minerals.

There are also ore testing plants at the principal mining sehools in ('anada, including the Nora scotia Technieal sichool, Halifax, N.S.; the L'niversity of MeCiill, Montreal; Kingston Sehool of Mines, Quecn's University, Kingston; and the Eniversity of Toronto, Toronto, Ont.

A fuel testing station has been established by the Mines Branch at Ottawa, the Dominion of Canada Fuel T'esting Plant, to demonstrate that peat could be economically utilized ans a fuel for power purposes in a producer gas power plant, and to trist the fuel and power producing values-on a commercial seale and in a commercial gas producer - of the bituminous coals of the extreme eastem and western provinces and of the lignites of Manitoba, Alberta, and saskatchewan.

A plant is also about to be erected by the Government of the provinee of Saskatehewan at Estevan, for the purpose of assisting the development of the coal mining industry by testing the lignite coal of that district. 




Physical Sciences Library

DATE DUE 
Physical Sciences Library University of California

Riversice 


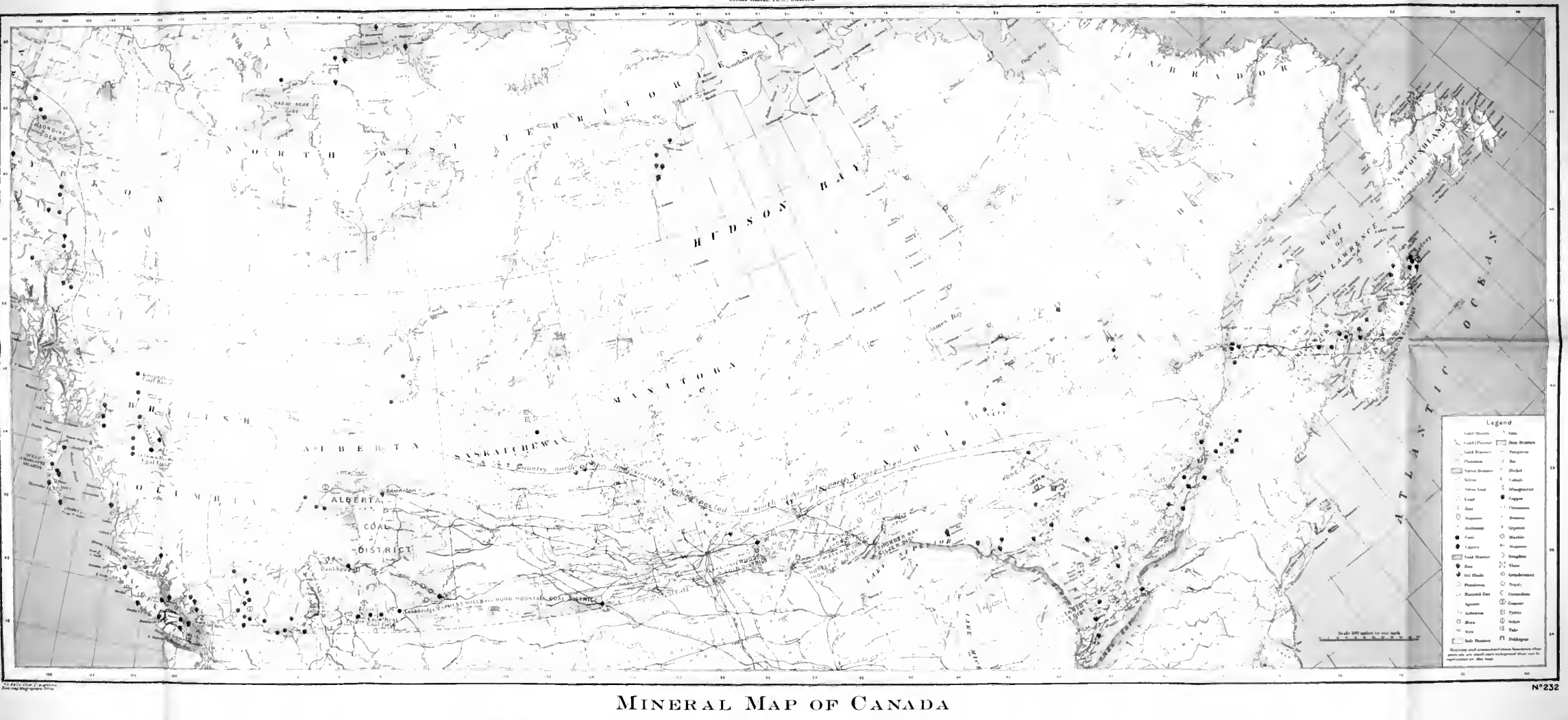




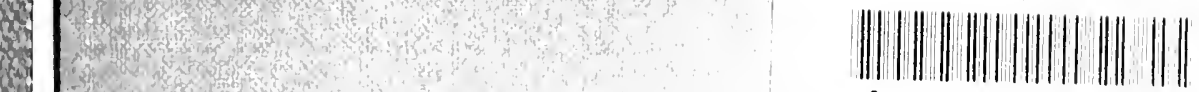

A 000595503 . 
